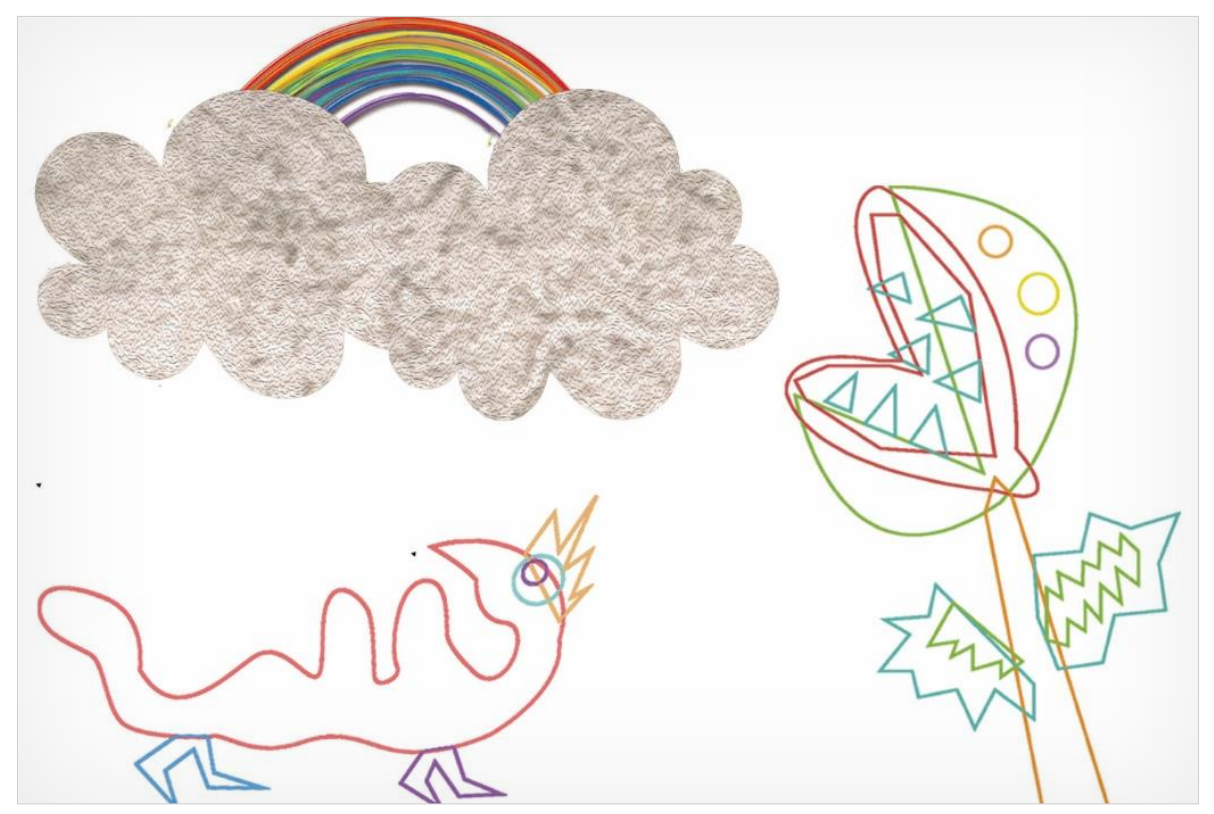

TFM Trabajo Fin de Master

Título:

RELACIÓN ENTRE TEXTO E IMAGEN EN LOS ÁLBUMES ILUSTRADOS INFANTILES DE CONTRAPUNTO. PROPUESTA DE CREACIÓN ARTÍSTICA.

Autora: Marta Vélez Borja

Tutora: $\mathrm{M}^{\mathrm{a}}$ Carmen Hidalgo Rodríguez

Máster Universitario en Dibujo: Creación, Producción y Difusión 2017/2018

Línea de Investigación en la que se encuadra el TFM: Ilustración.

Departamento de Dibujo.

Convocatoria: Septiembre

Año: 2018. 



\section{TFM $\mathbf{M}_{\text {Trabajo Fin de Master }}$}

Título:

RELACIÓN ENTRE TEXTO E IMAGEN EN LOS ÁLBUMES ILUSTRADOS INFANTILES DE CONTRAPUNTO. PROPUESTA DE CREACIÓN ARTÍSTICA.

Autora: Marta Vélez Borja

Tutora: $\mathrm{M}^{\mathrm{a}}$ Carmen Hidalgo Rodríguez

Máster Universitario en Dibujo: Creación, Producción y Difusión 2017/2018

Línea de Investigación en la que se encuadra el TFM: Ilustración.

Departamento de Dibujo.

Convocatoria: Septiembre

Año: 2018. 

2. OBJETIVOS 4

2.1 Objetivos generales.

2.2 Objetivos específicos.

3. METODOLOGÍA 5

\subsection{Teórica}

3.1.1 Referencias bibliográficas: Búsqueda y análisis de álbumes de contrapunto de las últimas décadas, tanto en un ámbito nacional como internacional.

3.1.2 Análisis cualitativo de los álbumes seleccionados.

3.2 Práctica

3.2.1 Proceso de creación artística en la elaboración de un álbum ilustrado. Desarrollo y resultado de dicha creación.

4. ESTADO DE LA CUESTION

4.1 Definición de conceptos.

4.2 Panorama actual de los álbumes ilustrados de contrapunto.

5.ÁLBUMES ILUSTRADOS DE CONTRAPUNTO 10

5.1 Prospección de álbumes.

5.2 Análisis de la muestra recogida.

5.3 Resultados y tipologías. 
5.3.1 Sobre el nivel de realismo y tipo de historia.

5.3.2 Sobre diferentes finales.

5.3.3 Sobre el nivel de realismo frente a tipos de historia.

5.3.4 Sobre los diferentes tipos de finales.

\section{CREACIÓN PLÁSTICA. PROYECTO DE ÁLBUM ILUSTRADO DE

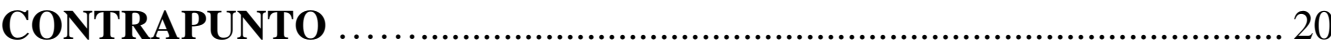

6.1 Idea y guión.

6.2 Diseño de los personajes y escenarios.

6.3 Story board y bocetos.

6.4 Ilustraciones definitivas, portada, contraportada y guardas.

6.5 Técnica y acabado.

6.6 Maquetación y resultado final.

7. CONCLUSIONES

8.1 Publicaciones.

8.2 Referencias en la Web.

8.3 Álbumes ilustrados. 


\section{RESUMEN}

En este proyecto se estudia la importancia de los álbumes ilustrados, concretamente los de contrapunto (donde texto e imagen dicen cosas diferentes), como medio creativo y pedagógico que potencia la imaginación y madurez de interpretación entre lo que hay escrito y lo que nos muestran las imágenes.

Es un trabajo teórico-práctico que se llevará a cabo mediante dos formas: una teórica, con el análisis de álbumes ilustrados, y una práctica, con la creación propia de un álbum.

Primero es necesario diferenciar entre los álbumes de contrapunto y los de complemento (aquí texto e imagen van de la mano), para posteriormente hacer una serie de análisis sobre libros ilustrados de contrapunto ya existentes, principalmente del S. XX y S.XXI, tanto en el panorama nacional como internacional, y así poder ver cómo actúan este tipo de álbumes. Dichos análisis, que se ven reflejados mediante unas plantillas creadas, nos muestran la relación que existe entre texto e imagen, el nivel de realismo que tienen ambos, e incluso como actúa uno frente al otro, entre otras cosas, dándonos así un tipo de historia diferente (bien alternativa o bien contradictoria) dependiendo de lo que nos dicen las ilustraciones frente a las palabras.

Tras esta búsqueda y estudio se procede al diseño y creación propia de un álbum ilustrado de contrapunto para aplicar todo lo previamente observado y analizado, del cual se muestra el proceso creativo con el diseño de personajes, storyboard, bocetos, texto, ilustraciones definitivas y maqueta final.

Palabras clave: Álbum ilustrado, contrapunto, relación texto e imagen, creatividad. 


\section{ABSTRACT}

This project examines the importance of the picture books, specifically those of counterpoint (where text and image say different things), as a creative and pedagogical medium that enhances the imagination and maturity of interpretation between what is written and what the pictures show us.

It is a theoretical-practical work that will be carried out in two ways: a theoretical one, with the analysis of illustrated albums and a practice, with the creation of an álbum.

First it is necessary to differentiate between the albums of counterpoint and the álbum of complement (here text and image go hand in hand), to then make a series of analysis on already existing illustrated counterpoint books, mainly of the 20th century and 21st century, both nationally and internationally, and so be able to see how these types of albums work. These analyzes that are reflected by templates created, show us the relationship between text and image, the level of realism that have both, and even how one acts against the other, among other things, giving us a different story (alternative either or contradictory) depending on what the illustrations tell us in front of the words.

After this search and study is the design and own creation of an illustrated album of counterpoint to apply all the previously observed and analyzed, which shows the creative process with the design of characters, storyboard, sketches, text, final illustrations and final model.

Key words: Picture book, counterpoint, relationship between text and image, creativity. 


\section{INTRODUCCIÓN}

El proyecto se centra en los álbumes ilustrados y en la relación que existe entre texto e imagen, junto con la propuesta de creación de un álbum propio, donde se pondrá en práctica los conocimientos adquiridos. Partiendo de la clasificación realizada por Nikolajeva (2006), que divide en un primer momento a los álbumes ilustrados en complemento y contrapunto (en función de la relación entre texto e imagen), la investigación que se presenta se centra en los álbumes ilustrados de contrapunto, dejando fuera los álbumes de complemento, y en cómo este tipo de libros pueden influenciar positivamente en el desarrollo de la creatividad de los niños, así como en su capacidad de madurez interpretativa.

Los álbumes ilustrados de contrapunto suponen un medio ideal para fomentar la imaginación, puesto que texto e imagen cuentan historias distintas que pueden contradecirse o no, y frente a la cual el lector adopta un papel activo. En los álbumes de complemento, en cambio, tanto texto como imagen cuentan la misma historia rellenando ambos medios los vacíos del otro. El hecho de seleccionar los álbumes de contrapunto para su análisis, y dejar fuera los de contrapunto, no quiere decir que unos tengan más importancia que otros, puesto que la valía de un álbum ilustrado no reside en esta característica, aunque pueda influir. El motivo se basa en la escasez de álbumes de contrapunto frente a los de complemento y con ello un menor estudio de estas publicaciones.

La complejidad que conlleva en ocasiones este tipo de publicaciones, destinadas a un público infantil en la mayoría de los casos, puede hacer que, en un principio, el niño tenga dificultades para entenderlo, pero es precisamente este esfuerzo que requiere del lector uno de los atractivos del álbum y a medida que retoman el libro van descubriendo cosas nuevas.

Por lo tanto, con este trabajo se pretende demostrar la importancia del álbum ilustrado de contrapunto como recurso creativo y didáctico que potencia la madurez de interpretación lectora del niño, tanto de textos escritos como de imágenes visuales, a la vez que fomenta la creatividad debido a la riqueza de interacción entre texto e imagen que encontramos en estas publicaciones. 
Antes de seguir me gustaría comentar un poco acerca de la elección del TFM. Hace unos años estudié magisterio de primaria, donde tratamos la literatura infantil y pudimos ver y trabajar con álbumes ilustrados. Esto me pareció muy interesante ya que mezclaba dos cosas que me gustaban mucho: la educación y el dibujo por lo que decidí hacer el Trabajo Final de Grado sobre ello.

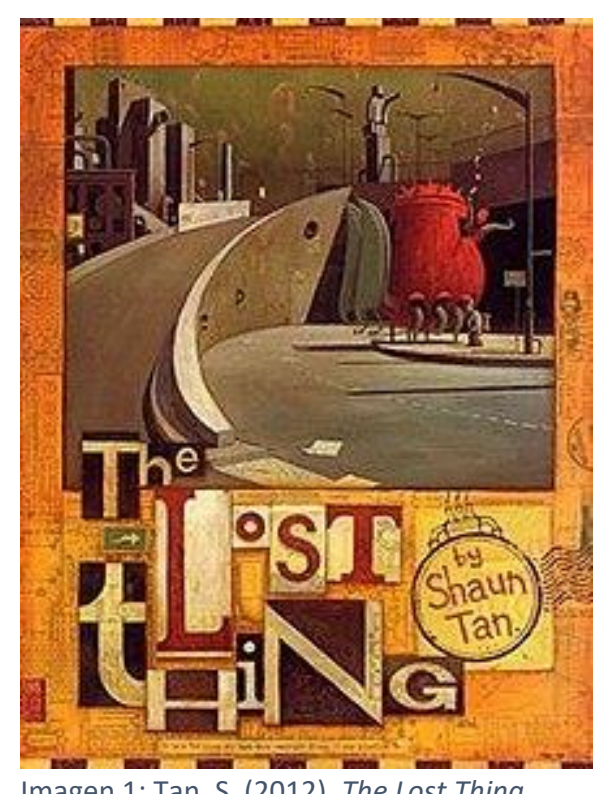

Imagen 1: Tan, S. (2012). The Lost Thing.
En el Trabajo Fin de Grado analicé el álbum de Shaun Tan (2012) The Lost Thing (la cosa perdida), el cual pude aplicarlo a una clase de sexto con edades comprendidas entre los 11 y 12 años. Era un libro complejo para esa edad, así que probé y mi sorpresa fue que una niña concretamente, profundizó en casi todas las respuestas del test que planteé, frente al resto de compañeros. El resultado fue bastante atrayente y empecé a interesarme por este tipo de libros.

Este año, en el Máster de Dibujo y específicamente en la asignatura de ilustración infantil, tuve la oportunidad de crear una propuesta de álbum ilustrado y todo lo que ello conlleva, desde la idea y el planteamiento, hasta la elección y creación de personajes, título, texto, storyboard, bocetos, ilustraciones definitivas y maquetación. Me pareció bastante atractivo ya que antes lo había visto desde fuera, es decir, había tratado con este tipo de libros infantiles, pero nunca había creado uno. Es un campo tan abierto que te da múltiples posibilidades, además es una forma de educación en valores, así como de forma de expresión.

Tras lo anteriormente comentado, he seleccionado una serie de álbumes ilustrados de contrapunto (que no son sencillos de encontrar, puesto que este tipo no es el más común) los cuales son analizados mediante una plantilla creada, para así poder ver la relación que existe entre las imágenes y las palabras. Estos álbumes seleccionados son tanto nacionales como internacionales (aunque estén reeditados) y abarcan desde casi mediados del siglo XX hasta hace unos años. 
Cada plantilla consta de dos partes:

-Datos teóricos: compuesto por el título, autor e información sobre las publicaciones, así como un breve resumen.

-Relación texto e imagen: se analiza lo que cuenta la historia según el texto, según la imagen y según ambos; los recursos utilizados en cuanto a nivel de realismo entre ilustraciones y palabras; el tipo de historia teniendo en cuenta lo que nos dicen las ilustraciones respecto a las palabras (si es contradictoria con toques de humor o ironía, o si nos da una historia alternativa); y el tipo de final con una o varias posibilidades.

El público al que va dirigido es principalmente infantil, aunque la mayoría de ellos se puede dar en un público juvenil e incluso adulto ya que tienen múltiples posibilidades.

Aunque mi proyecto consiste en el análisis de libros que ya existen en el mercado y creación de uno nuevo, no incluye la aplicación de estos en un ámbito infantil, por razones temporales, sin embargo, sería bastante interesante comprobar su eficacia ante el público objetivo en el futuro.

En los siguientes apartados hablaremos de los objetivos tanto generales como específicos y de la metodología (teórica-practica) empleada. Además, comentaremos el estado de la cuestión de este tema en concreto, así como las distintas tipologías encontradas en los álbumes de contrapunto.

Finalmente se expone el proceso llevado a cabo en la creación de un álbum ilustrado infantil de contrapunto. Se plantea el proyecto completo que incluye: bocetos y diseño de personajes, texto, storyboard, bocetos definitivos de cada doble página, dos ilustraciones definitivas y la maquetación completa con cubiertas, portada y guardas. 


\section{OBJETIVOS}

\subsection{Objetivos generales}

- Poner en valor el álbum ilustrado como recurso educativo destacando su potencial creativo.

- Estudiar las relaciones que se crean entre texto e imagen en los álbumes ilustrados de contrapunto destinados al público infantil, respecto al álbum de complemento.

- Analizar este tipo de libros para comprobar su eficacia comunicativa con el público infantil y juvenil.

- Destacar el interés de este tipo de libros con respecto a los álbumes ilustrados convencionales.

\subsection{Objetivos específicos}

- Analizar y profundizar en los álbumes ilustrados de contrapunto.

- Estudiar autores y publicaciones claves de este tipo de álbumes en las últimas décadas.

- Estudiar los mecanismos que utilizan estos libros para configurar la historia.

- Localizar posibles dificultades que puedan generar los álbumes ilustrados de contrapunto, donde texto e imagen nos cuentan historias diferentes.

- Diseñar y crear una propuesta de álbum ilustrado de contrapunto. 


\section{METODOLOGÍA}

Este trabajo es teórico-práctico así que procede a elaborar dos fases bien diferenciadas. La fase teórica ha sido llevada a cabo en primer lugar, con idea de ampliar mis conocimientos sobre este tipo de publicaciones y que pudieran ayudarme en la propuesta plástica.

\subsection{Teórica}

Este apartado consiste en la investigación de los álbumes ilustrados de contrapunto y el análisis de los mismos. Para la elaboración de los mismos se han seguido los diferentes sistemas metodológicos:

3.1.1 Referencias bibliográficas: Búsqueda tanto de álbumes de contrapunto de las últimas décadas, de ámbito nacional e internacional, como publicaciones teóricas sobre este género.

Aquí se profundizará en libros que hablan sobre los álbumes ilustrados, concretamente los de contrapunto para así tener una base de conocimiento sobre ellos. En este sentido destacan las publicaciones de Martin Salisbury (2004) como Ilustración de libros infantiles e incluso con la colaboración de Styles (2012) en El arte de ilustrar libros infantiles. Otro libro atractivo para este tema es How picturebooks work de Nikolajeva y Scott (2006).

También hay que destacar en este punto artículos especializados como The Interaction between Text and Image in Picturebooks: Analysis of Story Books Published in Spain Today, escrito por Hidalgo Rodríguez (2015) o La interacción texto /imagen en el cuento ilustrado. Un análisis multimodal de Moya Guijarro (2007).

\subsubsection{Análisis cualitativo de los álbumes seleccionados.}

Puesto que tanto en libros teóricos como en internet viene poca información acerca de la tipología de álbum (en función de la clasificación entre complemento y contrapunto), hay que buscar dichos álbumes tanto en las bibliotecas de la facultad, como en bibliotecas online para poder analizarlos. 
Conjuntamente, se realiza el diseño de una plantilla de análisis para tratar los libros de contrapunto y poder considerar en profundidad cada álbum elegido en función de los mensajes que transmite la imagen por un lado, el texto por otro, y los dos en su conjunto para comprobar cómo están tratados, si son fáciles de entender para los niños y si promueve la imaginación debido a la relación entre lo escrito y lo visual. Con esto se pretende comprender los mecanismos de los que se valen estos libros para crear la historia.

\subsection{Práctica}

En esta parte se propone un proyecto de álbum ilustrado de contrapunto.

3.2.1 Proceso de creación artística en la elaboración de un álbum ilustrado. Desarrollo y resultado de dicha creación.

Se planteará y desarrollará una propuesta de un álbum ilustrado. Antes de nada es importante tener la idea sobre la que tratará la historia. En este caso se presenta el tema de la familia y de cómo los niños en muchas ocasiones, ven a sus madres. A través de la imaginación y creatividad de nuestra niña protagonista, podremos observar lo que para ella significa su madre, y cómo la dota de atributos especiales para convertirla en su superheroína favorita. Por lo que se llevará a cabo todo el proceso necesario de diseño, tal como planteamiento de la idea, desarrollo del texto, diseño de personajes, storyboard correspondiente, los bocetos iniciales y bocetos previos a las ilustraciones finales, dos ilustraciones definitivas, construcción del monstruo y maquetación. 


\section{ESTADO DE LA CUESTION}

Este punto consiste en la indagación de la bibliografía que existe sobre los álbumes ilustrados y álbumes ilustrados de contrapunto. Esto nos ayudará a establecer y valorar las diferentes líneas de investigación que constan sobre dicho tema.

\subsection{Definición de conceptos.}

Cuando hablamos de álbumes ilustrados o libro-álbum, nos referimos a los libros donde las ilustraciones llevan el peso de la narración. Según Salisbury (2004) el término libro-álbum, se aplica a los libros que recurren principalmente a las imágenes para contar una historia, usando pocas líneas como texto de apoyo. Aquí el aspecto más importante es el visual, ya que nos cuenta aquello que las palabras no pueden expresar, por lo que se puede emplear incluso con los más pequeños, aquellos que aún no saben leer y que mientras alguien les lee, ellos observan las imágenes y crean su historia.

Además, otro punto positivo, es que existe una gran variedad de temas diferentes que se pueden tratar con los niños. Temas serios, cargados de valores, divertidos o simplemente que nos cuentan algo, los cuales son un gran instrumento lleno de riqueza creativa y enseñanza en la literatura infantil.

En una gran cantidad de casos, autor e ilustrador es la misma persona, lo cual lo hace mucho más personal.

Si tenemos en cuenta el grado de interacción entre texto e imagen, podemos clasificarlos en álbumes de complemento o de contrapunto. Acogiéndonos a la clasificación que hace Nikolajeva y Scott (2006) se habla de complemento cuando "las palabras y las imágenes se llenan por completo, no queda nada para la imaginación del lector, y el lector permanece un tanto pasivo”. Esto sucede si lo que dice el texto e imagen se complementan ya que van en la misma dirección, de manera que la información queda completa, por lo que no deja que el lector desarrolle su creatividad de interpretación. También se refieren a contrapunto cuando lo que nos cuentan las palabras e imágenes son historias diferentes, proporcionándonos "información alternativa o contradictoria", por lo que 
tendremos "una variedad de lecturas e interpretaciones". Es decir, dependiendo de la relación que existe entre lo que vemos y lo que hay escrito, texto e ilustraciones actúan de forma independiente haciendo que la historia pueda ser contada desde una perspectiva diferente y alternativa, o desde un punto de vista irónico y contrario.

Este tipo de libros les dan la oportunidad a los niños de ver más allá de lo que el protagonista ve y de tratar varias historias en un mismo libro. Lo que se pretende, es poner de manifiesto la importancia del uso de la imagen en álbumes ilustrados tanto complementando el texto como aportando información diferente, la cual puede ser contradictoria en algunos casos con respecto a lo que dice el texto; y como la ilustración ayuda a transmitir una gran cantidad de valores y sentimientos, así como refuerza el desarrollo de la creatividad y madurez de interpretación dejando a su vez un amplio campo abierto para la imaginación.

El trabajo irá conducido en principio hacia el análisis de álbumes ilustrados de contrapunto ya existentes, con el fin de estudiar los mecanismos que utilizan estos libros para configurar la historia, y finalmente poder llevar a cabo la creación de uno.

\subsection{Panorama actual.}

Es cierto que el álbum ilustrado en sí está en auge tanto a nivel nacional como internacional. Y aunque también existe información sobre ellos, bien artículos o libros, éste énfasis no es tan grande si nos referimos concretamente a los álbumes ilustrados de contrapunto.

Son muchos los artículos que hablan sobre álbumes ilustrados. Algunos están relacionados con la educación como lo hace por ejemplo Senís Fernández (2014) el cual nos habla en su artículo sobre el álbum ilustrado como uno de los principales materiales impresos a los que acceden los niños y las niñas en sus primeras etapas del aprendizaje y que sirve como instrumento de educación literaria, artística, y social. 
También existen artículos y publicaciones que hablan sobre la interacción entre texto e imagen en los álbumes ilustrados. Este tema aparece por ejemplo en el artículo de Moya y Sanz (2007), donde trata sobre las relaciones entre las ilustraciones y palabras para crear un significado, tanto a nivel textual como visual en el cual diferencian entre álbumes de complemento y contrapunto. Así mismo, en este tema, Hidalgo (2015) nos habla además de las diferentes posibilidades de relación entre las imágenes y el texto en el álbum a partir de la clasificación de álbumes de contrapunto y complemento, profundizando en distintas tipologías en función de los recursos e información que aporta el ilustrador. Asimismo, se refiere a los álbumes ilustrados como un medio de educación, tanto para disfrutar de ellos como para expresar la creatividad. En este punto también podemos incorporar a Chiuminatto (2011), quien en su artículo nos aclara que las relaciones de la imagen junto con el texto, son un factor muy importante para incentivar la lectura.

Dentro del campo de los álbumes infantiles, los menos estudiados son los que hemos llamado álbumes de contrapunto, encontrando poco manuales de investigación que traten el tema. Entre estas publicaciones destacan por ejemplo, Salisbury y Styles (2012), quienes reúnen información necesaria tanto de conceptos como de análisis de álbumes ilustrados infantiles.

Del mismo modo Nikolajeva y Scott (2006) son grandes referentes en cuanto al estudio de los álbumes ilustrados y lo reflejan en su libro donde hacen clasificaciones dependiendo de la relación entre la imagen y el texto y de nuevo examinan una gran cantidad de álbumes. 


\section{5. ÁLBUMES ILUSTRADOS DE CONTRAPUNTO.}

En este capítulo hablaremos sobre los resultados obtenidos tras el análisis de catorce álbumes ilustrados infantiles de contrapunto, para un posterior análisis (a través de una plantilla creada) en cuanto a relación entre texto e imagen y así obtener unos resultados concretos a partir de las diferentes tipologías que aparecen.

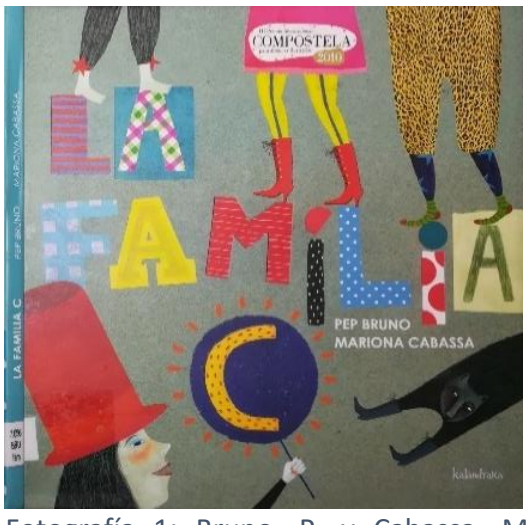

Fotografía 1: Bruno, P. y Cabassa, M. (2010). La familia. Ed. Kalandraka.

\subsection{Prospección de álbumes.}

Para la investigación de los álbumes ilustrados infantiles de contrapunto he buscado por diferentes medios. Es cierto que encontrar álbumes ilustrados es fácil, sin embargo los álbumes ilustrados de contrapunto son un tipo de libros menos frecuentes, por lo que al hacer la prospección he encontrado dificultades.

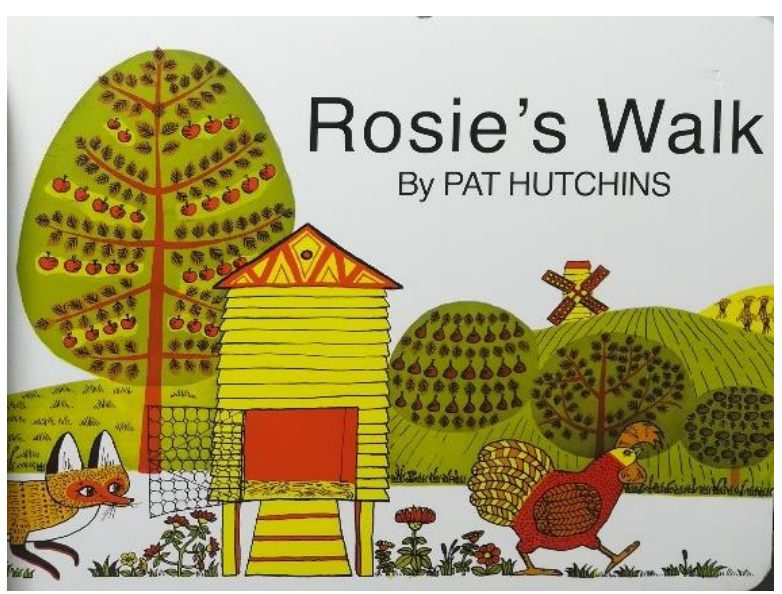

Fotografía 2: Hutchins, P. (2015). Rosie's walk. Ed. Little Simon.

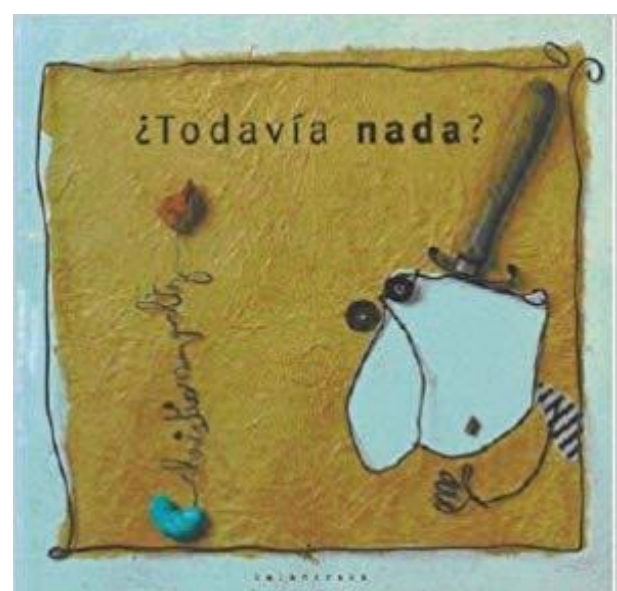

Fotografía 3: Voltz, C. (2003). ¿Todavía nada? Ed. Kalandraka.

Algunos sí aparecen referenciados e incluso analizados en ciertos libros teóricos (como los mencionados anteriormente de Salisbury y Styles (2012), o de Nikolajeva y Scott (2006)), pero son solo una pequeña cantidad, por lo que tuve que hacer una búsqueda intensiva con el fin de poder ampliar mi muestra a analizar. 


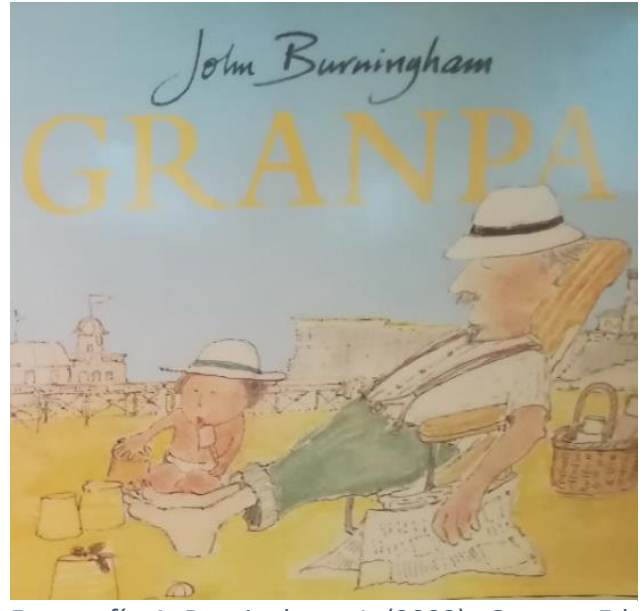

Fotografía 4: Burningham, J. (2003). Granpa. Ed. Red fox.

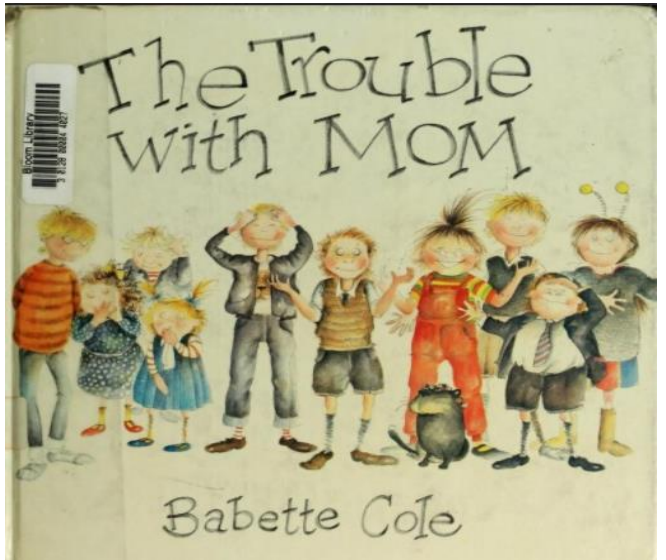

Fotografía 5: Cole, B. (1984). The trouble with mum. Recuperado de:

https://archive.org/details/troublewithmom00cole

De los 14 libros encontrados y finalmente analizados, estos pueden ser clasificados según año de primera publicación y lugar. Por ello he comprobado y registrado que tan solo 1 de los 14 es nacional; 10 son internacionales; y 3 son de autores e ilustradores españoles, pero publicados en editoriales internacionales.

Por otra parte, 6 de los 14 pertenecen al Siglo XXI (3 a la primera década y 3 a la segunda); por lo que 8 corresponden a la segunda mitad del Siglo XX. Lo anteriormente escrito se refiere a las primeras publicaciones, no a las reediciones.
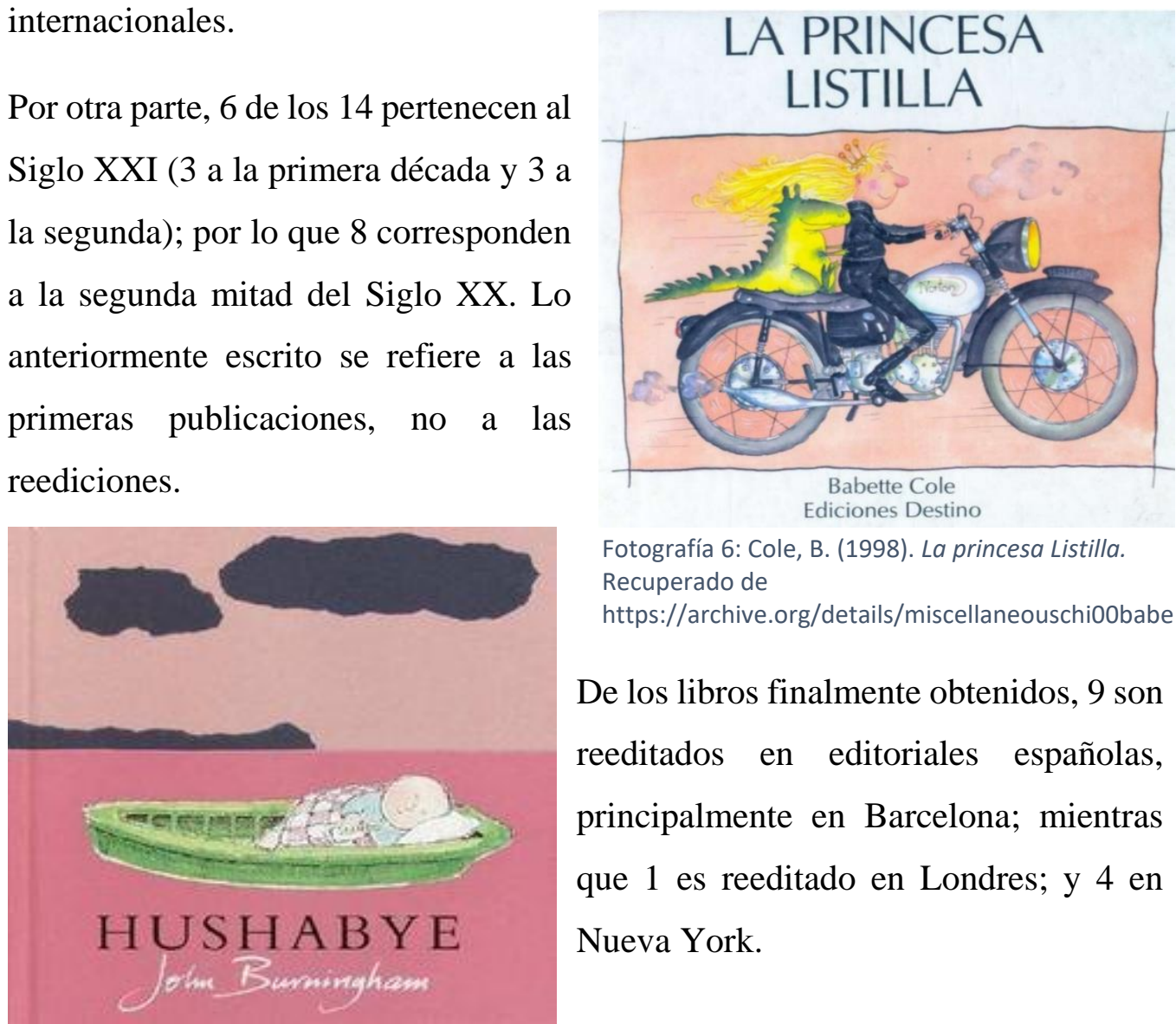

Fotografía 6: Cole, B. (1998). La princesa Listilla. Recuperado de

https://archive.org/details/miscellaneouschi00babe

De los libros finalmente obtenidos, 9 son reeditados en editoriales españolas, principalmente en Barcelona; mientras que 1 es reeditado en Londres; y 4 en Nueva York.

Fotografía 7: Burningham, J. (2001). Hushabye. Recuperado de

https://archive.org/details/hushabye00john 
Finalmente en cuanto a la búsqueda y localización de los álbumes, la gran mayoría (9) los he conseguido en la Biblioteca de la Universidad de Bellas Artes; 1 en la Biblioteca de la Universidad de Educación; y 4 en una biblioteca online.

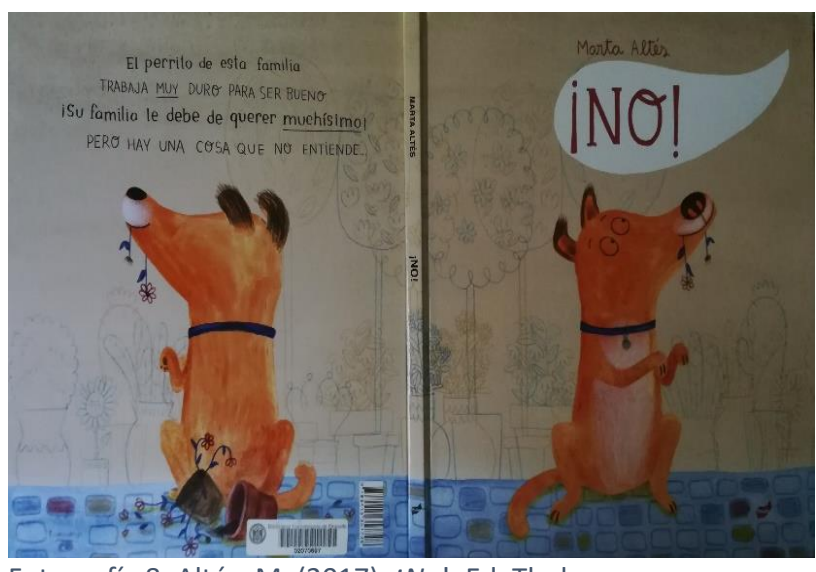

Fotografía 8: Altés, M. (2017). iNo!. Ed. Thule.

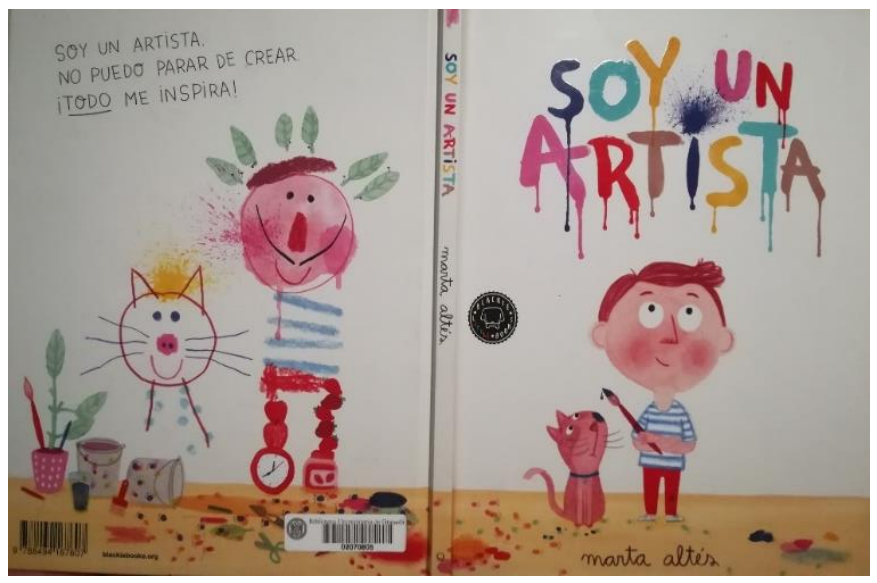

Fotografía 9: Altés, M. (2017). Soy un artista. Ed. Blackie Books S.L.U..
Aunque la mayoría de los álbumes ilustrados de contrapunto que he conseguido han sido reeditados en España (pero no creados), este tipo de álbumes van siendo, poco a poco, más conocidos en nuestro país.

Sin embargo, aunque las editoriales españolas trabajen con este tipo de libros, no existen gran cantidad de autores o ilustradores españoles que realicen álbumes de contrapunto. Aunque es cierto, como hemos podido comprobar, que el auge está siendo en esta última década, por lo que podemos pensar que es ahora cuando en España se está trabajando con ellos.

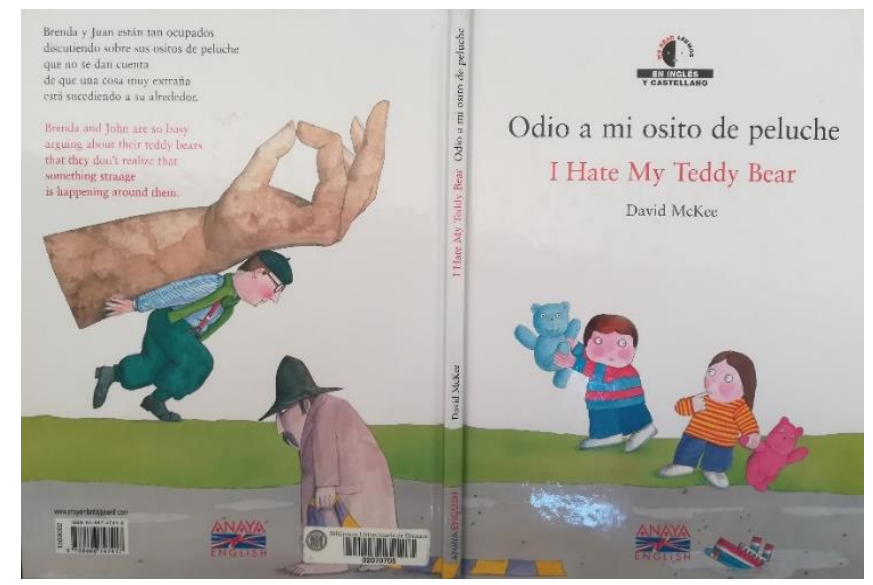

Fotografía 10: McKee, D. (2005). Odio a mi osito de peluche. Ed. Anaya. 
Los álbumes ilustrados de contrapunto examinados son:

-Una casa para el abuelo, de Grassa Toro e Isidro Ferrer.

-La familia C, de Pep Bruno y Mariona Cabassa.

- ¡No!, de Marta Altés.

-La historia de una manzana roja, de Jan Lööf.

-Rosie's walk, de Pat Hutchins.

-Granpa, de John Burningham.

-Lily takes a walk, de Satoshi Kitamura.

-Odio a mi osito de peluche, de David McKee.

-Soy un artista, de Marta Altés.

-El gato de Matilda, de Emily Gravett.

-La princesa Listilla, de Babette Cole.

-The trouble with mum, de Babette Cole.

-Hushabye, de John Burningham.

- ¿Todavía nada?, de Christian Voltz.

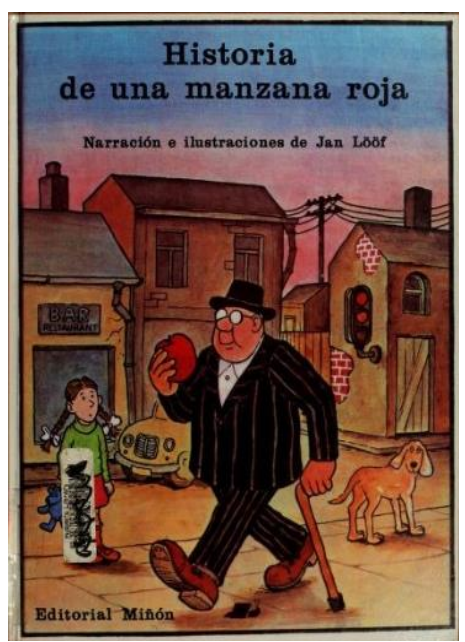

Fotografía 11: Lööf, J. (1987). La historia de una manzana roja. Recuperado

https://archive.org/details/historia

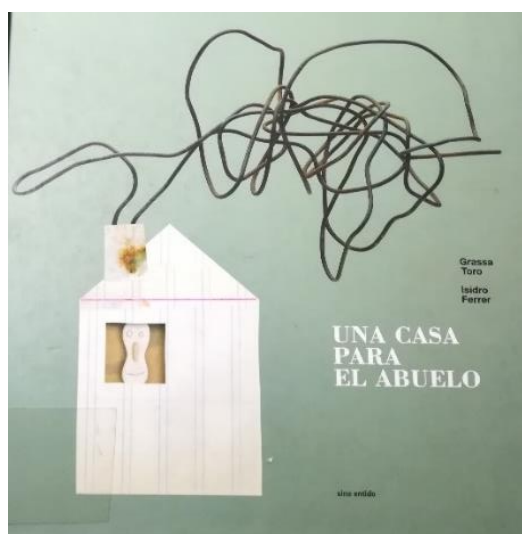

Fotografía 12: Toro, G. y Ferrer, I. (2007). Una casa para el abuelo. Ed. Sins entido.

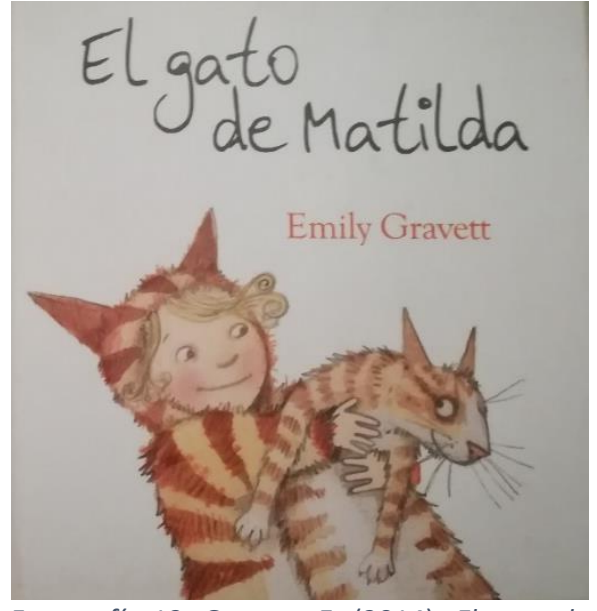

Fotografía 13: Gravett, E. (2014). El gato de Matilda. Ed. Picarona.

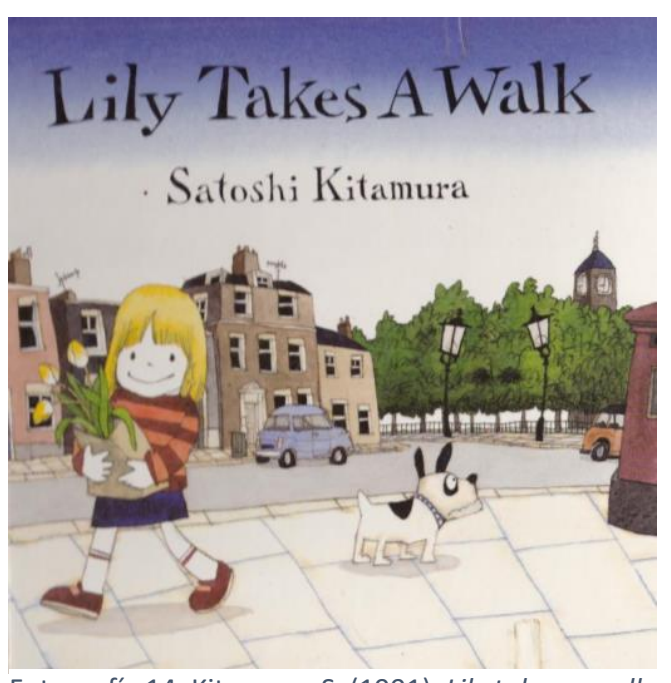

Fotografía 14: Kitamura, S. (1991). Lily takes a walk. Ed. Dutton children's book. 


\subsection{Análisis de la muestra recogida.}

Para el análisis de los álbumes ilustrados de contrapunto seleccionados, he realizado una plantilla que nos facilitará la recogida de información en un primer momento, y la extracción de resultados a posteriori. Los distintos análisis realizados a partir de los álbumes se recogen en el ANEXO 1. La plantilla creada es la siguiente:

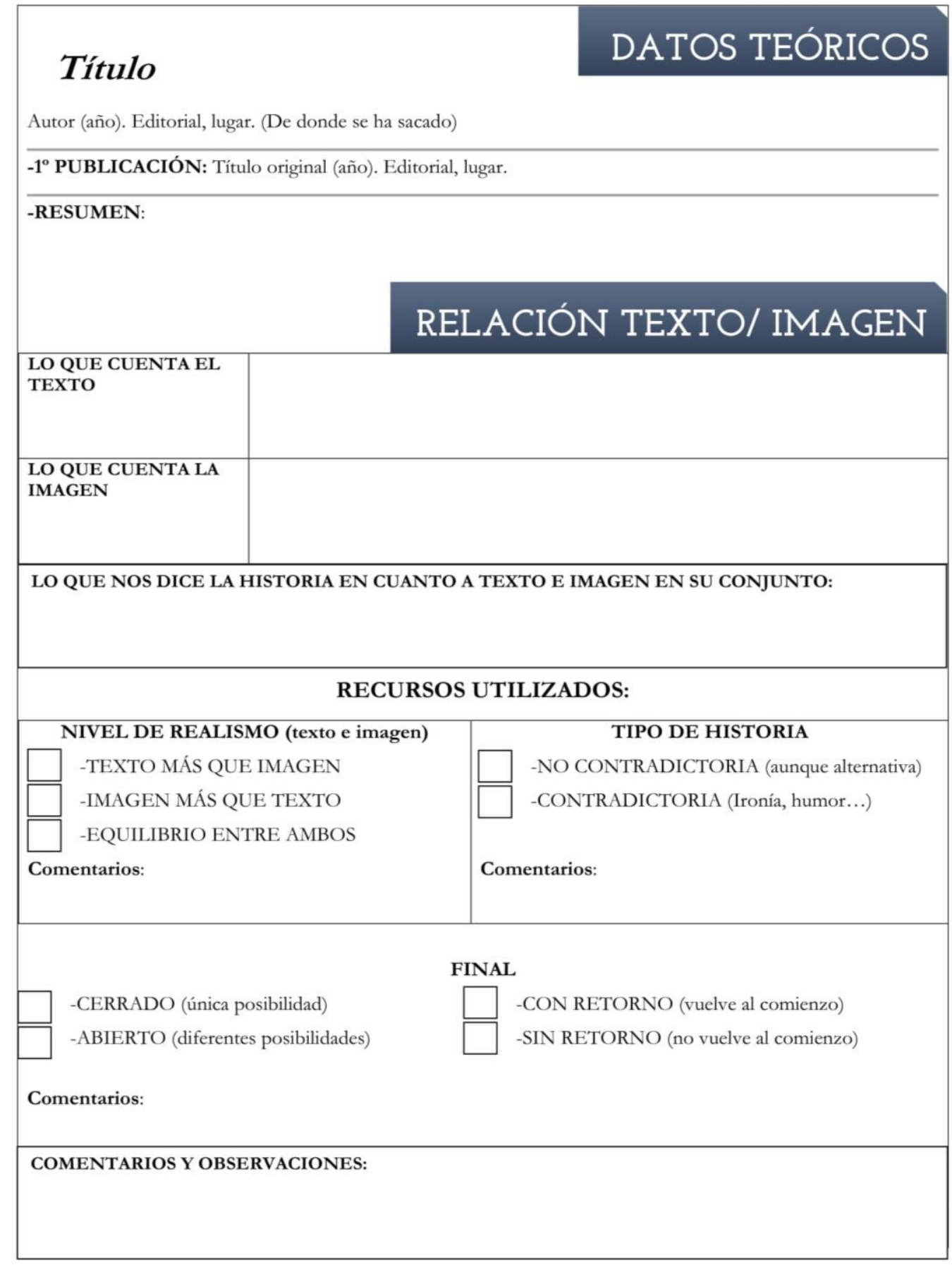

Imagen 2: Plantilla creada para el análisis de los 14 álbumes ilustrados de contrapunto. 
La plantilla primero comienza con los datos teóricos previos de cada álbum escogido así como un breve resumen. En el próximo apartado 5.3 se explica el resto de la plantilla. El análisis en sí se basa fundamentalmente en la relación entre texto e imagen y comienza con "lo que cuenta el texto con respecto a la imagen", "lo que cuenta la imagen frente al texto" y "lo que cuentan ambos a la vez". Esta parte es muy concisa, puesto que nos habla de forma particular de lo que cada uno de los álbumes nos trasmite tanto a nivel verbal como visual, además, nos ayuda a poder entender mejor y realizar el análisis posterior que se verá reflejado en los siguientes gráficos.

Estos gráficos hablan del "nivel de realismo entre texto e imagen", es decir, que es más realista, el texto, la imagen o los dos medios por igual; "tipo de historia", si es alternativa, contradictoria o si es una excepción de álbum de contrapunto, por lo que sería una historia de complemento pero con algunos detalles propios del contrapunto; "final", aquí se distingue entre final cerrado con una posibilidad o varias, y si vuelve al comienzo o no.

\subsection{Resultados y tipologías.}

En los siguientes apartados hablaremos de los resultados derivados en cuanto a las distintas variables analizadas.

Estos datos se han obtenido de los 14 álbumes ilustrados expuestos anteriormente.

5.3.1. Sobre el nivel de realismo y tipo de historia.

En este subapartado hablaremos sobre cuál es el nivel de realismo que destaca en los álbumes ilustrados anteriores, asi como que tipo de historia predomina. 


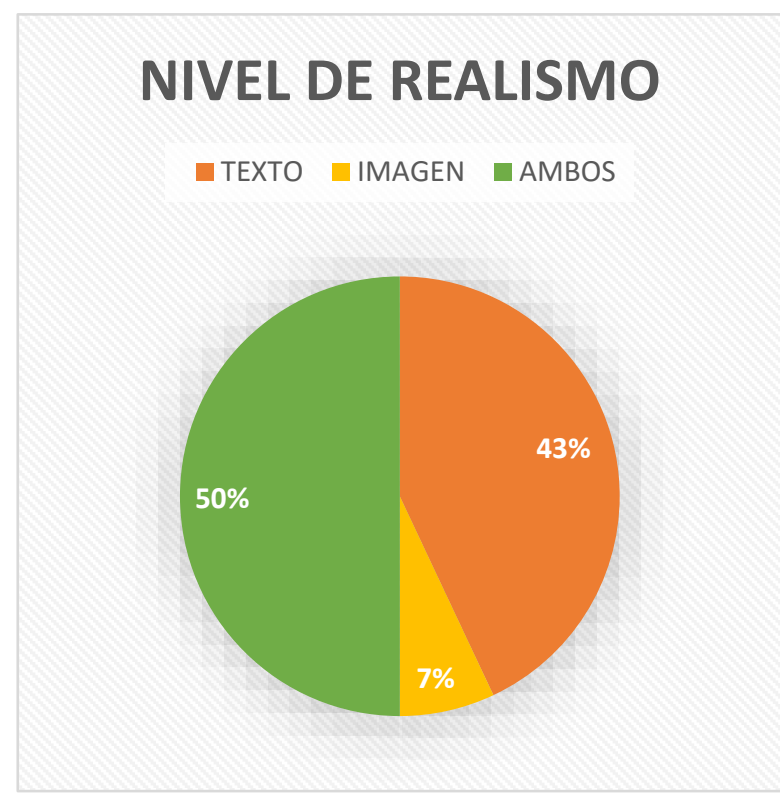

Gráfico 1: Nivel de realismo de los álbumes ilustrados de contrapunto analizados

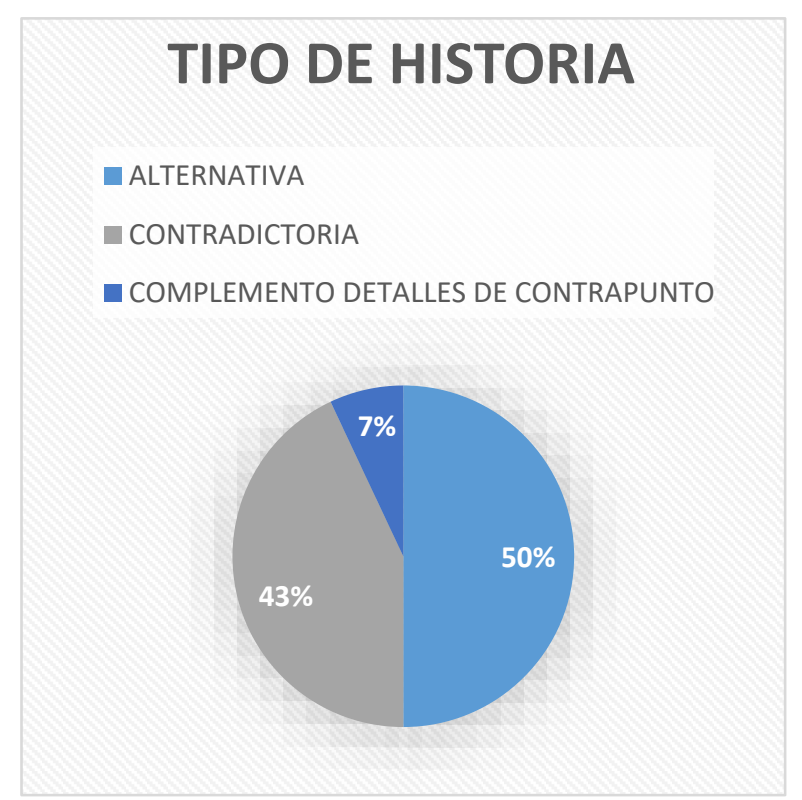

Gráfico 2: Tipo de historia de los álbumes ilustrados de contrapunto analizados.

En cuanto al nivel de realismo el grado de fantasía y creatividad en un álbum ilustrado lo asume normalmente la ilustración. Es cierto que en la muestra analizada el 50\% de los álbumes comparten este grado de realismo, sin embargo es muy poco usual que el texto asuma el papel fantástico en su totalidad ya que tan solo en un álbum el texto ocupa el papel creativo dejando a la imagen el realismo. Esto sucede en el álbum ilustrado de Granpa (2003), frente a seis álbumes donde es la ilustración la que ofrece el aspecto fantástico y el texto el realista.

El tipo de historia generalmente es no contradictoria o alternativa para la mitad de los álbumes analizados, donde las historias que nos dan las imágenes no contradicen a las del texto, si no que nos dan información visual por encima de lo que las palabras dicen. Por lo general, en cada álbum, las ilustraciones nos muestran diferentes historias que suceden al mismo tiempo.

Por el contrario, en casi la mitad de los casos, la historia narrada visualmente, suele contradecir a la textual. En estos álbumes, se suele jugar con la ironía o humor para poder crear con las imágenes una historia contraria, pero que a su vez tiene cierta relación con lo que el texto cuenta.

Tan solo en uno de los álbumes ilustrados analizados se da el caso de álbum de complemento con detalles de contrapunto, como sucede con el álbum de la historia de una manzana roja (1987) ya que, aunque toda la historia nos narra a 
nivel verbal lo que vemos, contiene páginas concretas que nos añaden información visual extra que no aparece en el texto y nos ayuda a comprender mejor la historia.

\subsubsection{Sobre diferentes finales.}

En esta sección tendremos en cuenta los diferentes finales posibles que se han obtenido tras dicha observación.

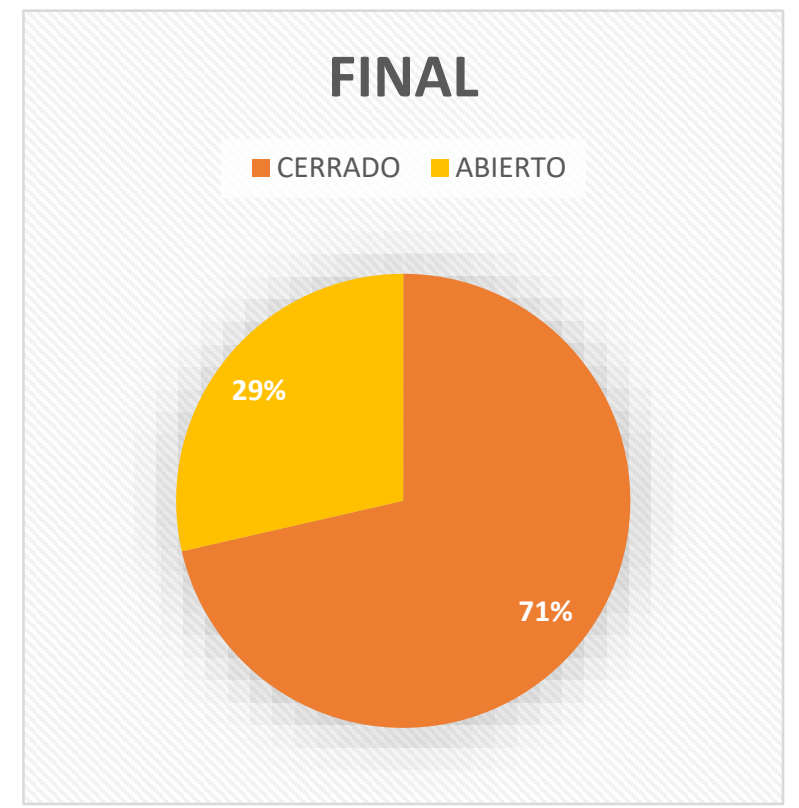

Gráfico 3: Tipo de final de los álbumes ilustrados de contrapunto analizados.

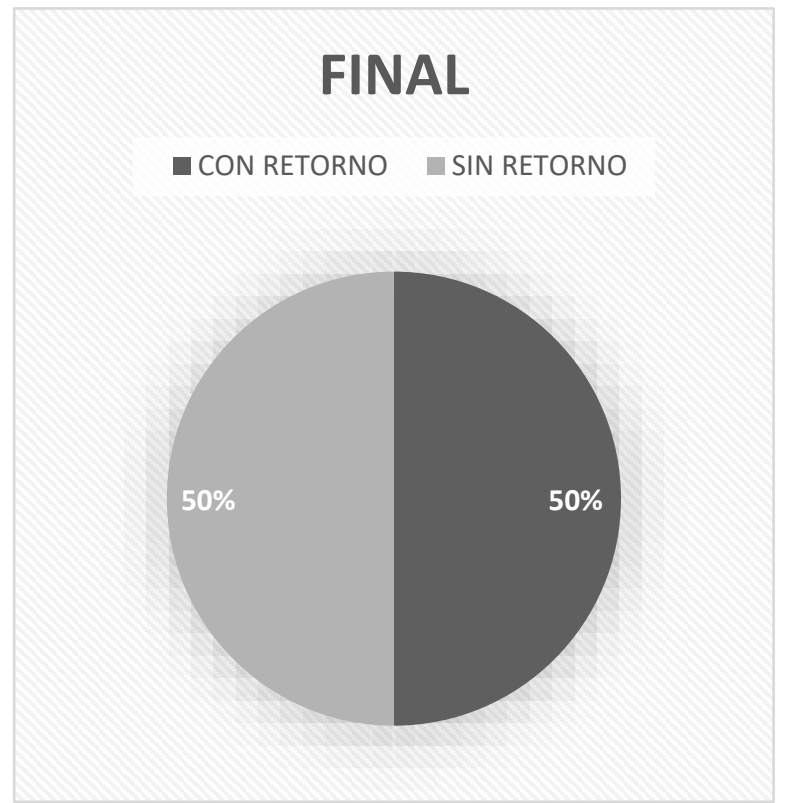

Gráfico 4: Tipo de final de los álbumes ilustrados de contrapunto analizados.

El final está dividido entre si es abierto o cerrado o con retorno y sin retorno.

La gran mayoría de los álbumes examinados corresponden con un final cerrado donde nos da una única posibilidad frente a una minoría cuyo final es abierto, es decir esos tipos de final dan varias posibilidades.

Si nos referimos al segundo tipo de final, la mitad corresponden con finales con retorno, es decir estos finales hacen referencia al principio de la historia. Por lo tanto la otra mitad pertenece a álbumes con finales sin retorno donde nada tiene que ver con el comienzo de la historia. 
5.3.3. Sobre el nivel de realismo frente a tipos de historia.

A partir de los resultados y combinando diferentes constantes, este epígrafe se refiere a los resultados obtenidos tras la combinación entre nivel de realismo y tipo de historia en los álbumes ilustrados infantiles de contrapunto analizados.

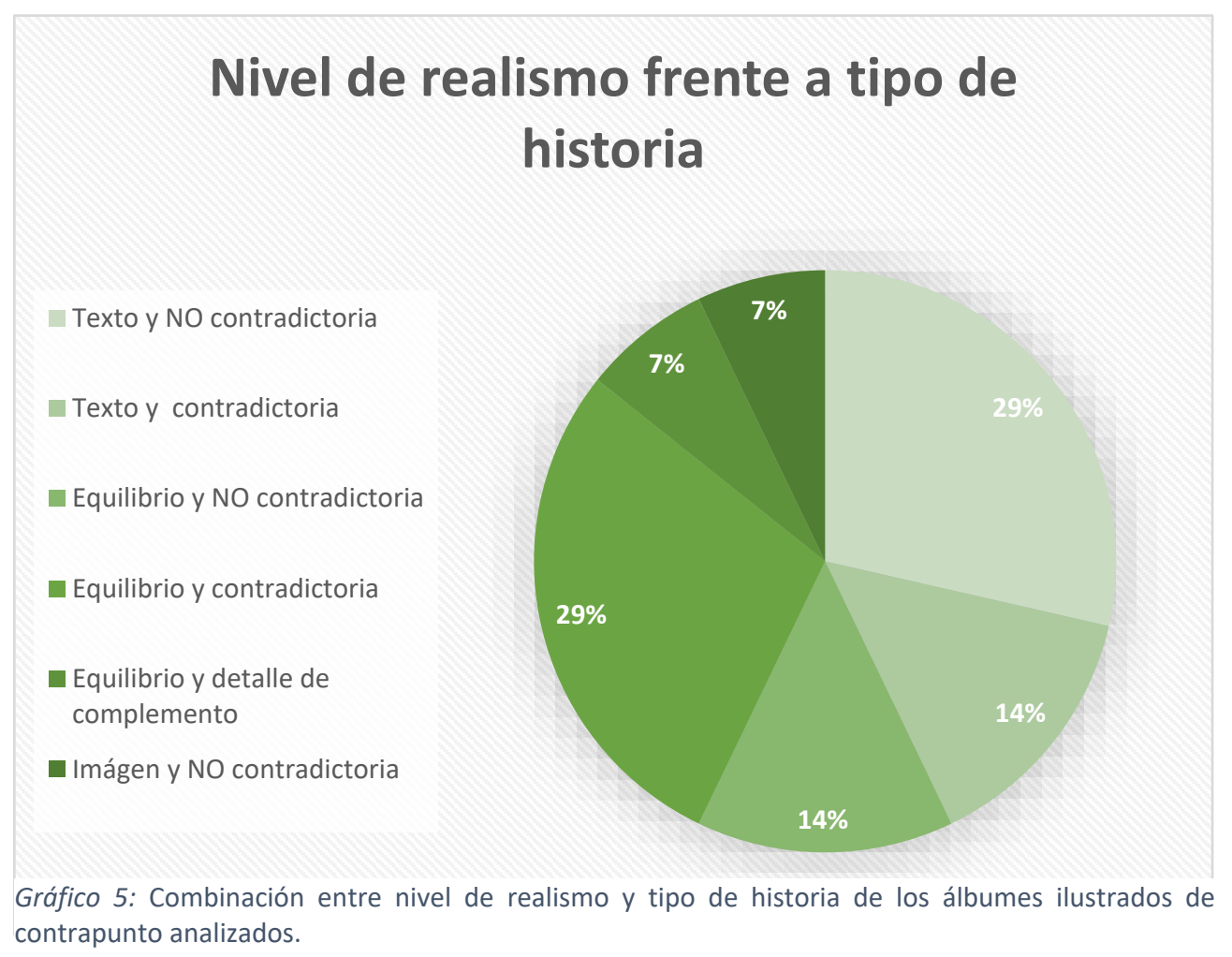

Si hacemos referencia a dicha combinación, podemos decir que la mayoría de los libros analizados donde la realidad del texto está por encima al de las imágenes, el tipo de historia es alternativa a lo que dice las palabras, es decir, no contradice al texto. Por el contrario, en la mayoría de los álbumes donde existe un equilibrio entre el nivel del realismo del texto e imagen, la historia si es contradictoria empleando toques de humor o irónicos.

Tan solo en uno de los casos, la imagen es más real que el texto, donde la historia es alternativa y no contradictoria. 
5.3.4. Sobre los diferentes tipos de finales.

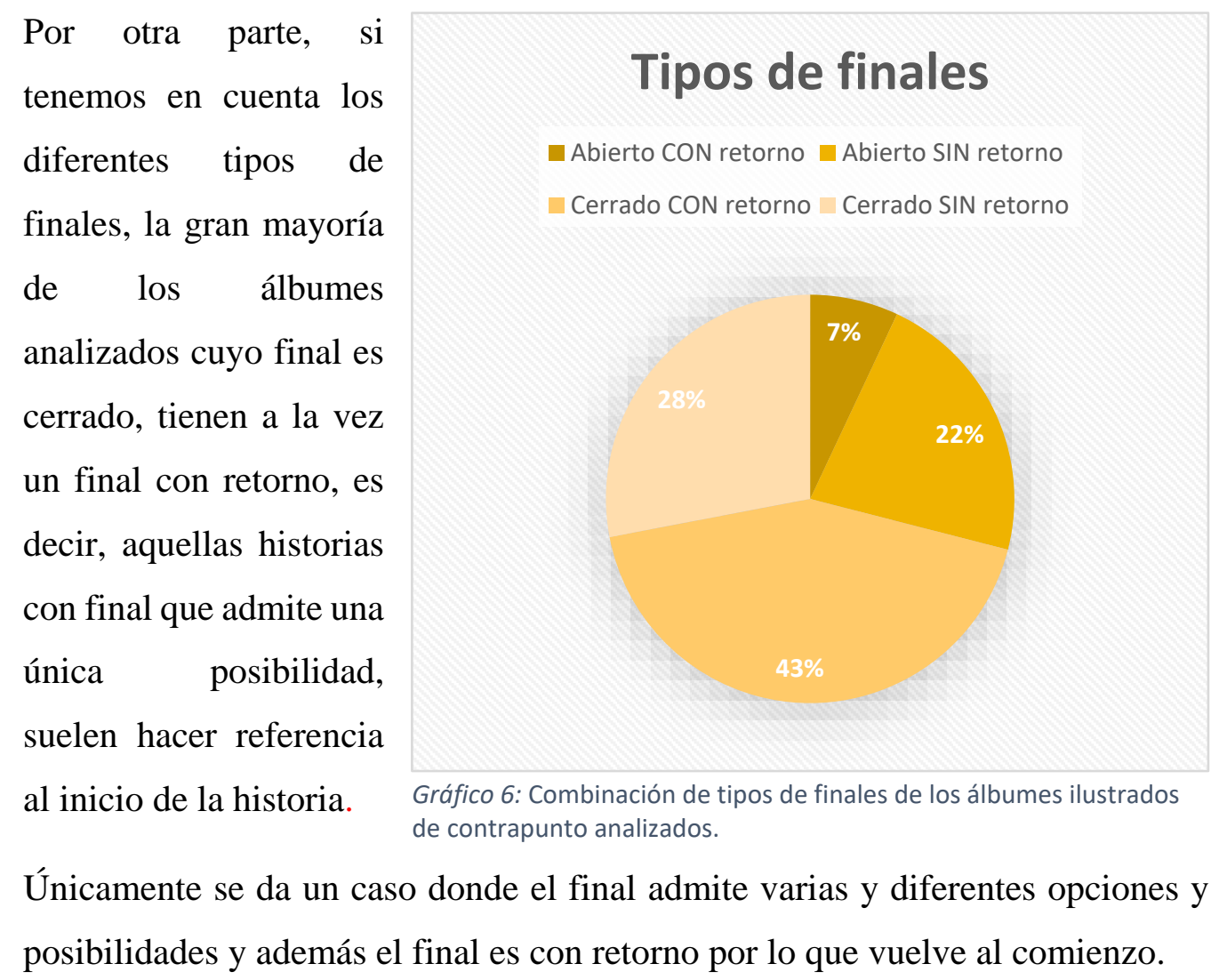




\section{CREACIÓN PLÁSTICA. PROYECTO DE ÁlBUM ILUSTRADO DE CONTRAPUNTO.}

En este punto nos centramos en el proceso que se lleva a cabo para crear un proyecto de álbum ilustrado infantil de contrapunto. El álbum que presentamos está destinado preferentemente al público infantile, como la mayoría de los álbumes ilustrados. En este trabajo presentaré todas las partes que componen un proyecto de ilustración e incluirá dos de las doce ilustraciones defintivas donde se puede ver la técnica final propuesta.

Antes de nada, recordaremos conceptos previos que hemos ido adquiriendo a lo largo de la investigación. Lo que pretendemos es crear esta idea de libro de contrapunto como recurso creativo y didáctico que potencia la madurez de interpretacion lectovisual e imaginación. De esta forma la intención es que el texto nos cuente una historia diferente a la que obtenemos de la imagen, intentando además jugar con los grados de realismo de ambos medios. No obstante, conscientes de la dificultad de este proceso, no queremos tampoco que esto pueda condicionar la historia que queremos contar, así que daremos prioridad a la creación artística aunque el resultado obtenido no sea del todo el contrapunto esperado. Hablaremos acerca del planteamiento de la idea y guión para este libro concreto, en que nos hemos basado para el diseño de los personajes, en que consiste el storyboard con los bocetos previos de la historia, los bocetos e ilustraciones definitivas, la técnica empleada y maquetación.

\subsection{Idea y guión.}

La propuesta de álbum de contrapunto pretende ponernos en la piel de una niña para comprender sus miedos u obstáculos. Principalmente lo que la historia nos cuenta es como una niña ve a su superheroína favorita, la cual es la única capaz de ayudarla a superar estos problemas. La niña nos habla desde el texto de su superheroina favorita, una superheroína diferente a la del resto de niños, que cuenta con una serie de poderes y es capaz de hacer de todo. La imagen, por otro lado, es la que aporta el lado más fantástico. En la historia completa se mezcla ficción y realidad donde problemas, miedos, u obstáculos cotidianos se exageran a los ojos de la niña, pero siempre son solucionados por su superheroína. Es al 
final cuando descubrimos algo que nos hará comprender la historia en sí (aunque se puede ir suponiendo), la madre es la superheroína a los ojos de la niña.

La historia es contradictoria ya que el texto nos dice una cosa, mientras que las imágenes que vamos viendo y relacionando, nos cuentan otra historia. En ningún momento se menciona la identidad de la heroína, hasta el final, por lo que si tapamos las imágenes o texto, nos salen historias relacionadas pero diferentes.

El texto para la propuesta de álbum es el siguiente:

- Un día la maestra nos pidió que dibujáramos a nuestros personajes favoritos y explicáramos por qué.

- Mis compañeros empezaron a decir de todo tipo: espadachínes, amazonas, genios, invulnerables.

- Pero yo lo tenía clarísimo, el mío sería diferente. Puede hacer de todo porque está muy entrenada.

- Se esconde como nadie y asi puede controlar la situación. A veces es difícil verla ya que se oculta en los lugares más insospechados.

- También compite con los aviones para ver quien vuela más alto.

- Es capaz de mover cielo y tierra cuando alguien necesita algo.

- Con su vista de lince, ve cosas que otros no pueden ver.

- Corre a la velocidad de la luz y ayuda a los demás si lo requieren.

- Mi superheroína favorita además hace magia. Transforma todo aquello que toca en cosas maravillosas.

- Para mejorar su elasticidad, se entrena rescatando criaturas en peligro.

- Y tiene tanta energía que es capaz de crear espacios protectores.

- Podría llamarse de cualquier manera, pero para mí solo tiene un nombre. ¡Mamá!. 


\subsection{Diseño de los personajes y escenarios.}

La protagonista principal es la superheroína. Para ello hubo varias propuestas, quien está basada en diferentes elementos de superhéroes como capa, antifaz para que no la reconozcan y un traje "especial". También lleva las iniciales MM, lo cual significa Mamá Maravilla (letras inversas de WW o Wonder Woman, pero en español), las cuales aparecen en el título del álbum (Superheroína M.M).

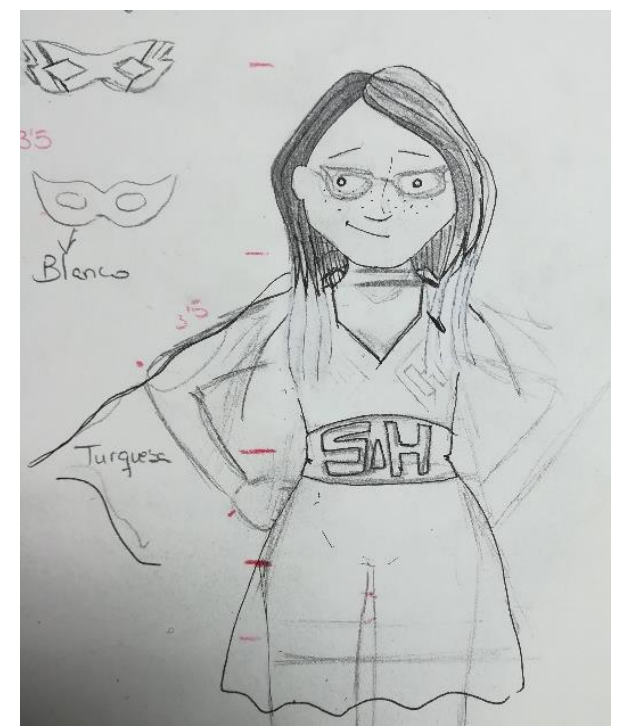

Ilustración 1: Primera propuesta de la Superherína (S.H).

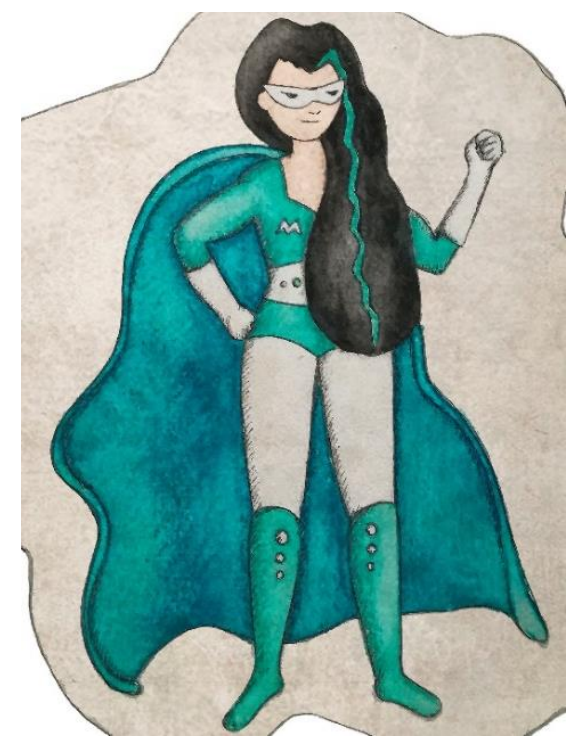

Ilustración 2: Propuesta final de la Superheroína.

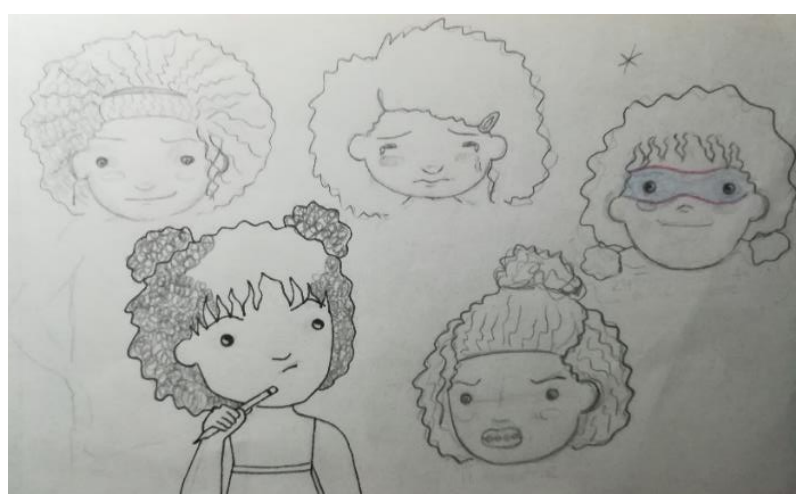

Ilustración 3: Diseño de la niña protagonista y narradora.

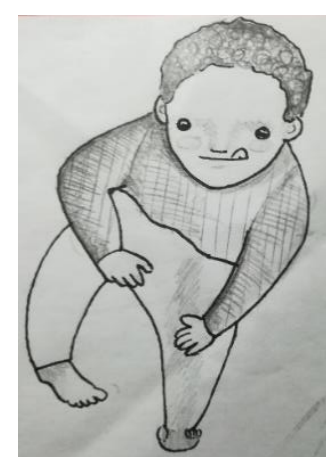

Ilustración 4: Hermano de la niña.

También existen más personajes con una gran importancia como la niña que narra, o su hermano pequeño, pero aparte, otra serie de personajes o elementos hacen que aunque la historia está formada por episodios diferentes, estos tengan una cierta relación: un osito de peluche por el que pelean los hermanos, que después aparece perdido y el hermano pequeño está buscando; la mascota de los 
niños, un gato que luego cae de un árbol; un oso gigante que hace referencia al cuento de los tres ositos (se puede ver por una foto de tres osos) y acaba raptando a la niña; o un perro que ladra y asusta a la niña.

Todo está lleno de detalles, pero los humanos son más reales. Los elementos fantásticos como los escenarios junto con "los miedos" o "problemas" están menos definidos y a veces juegan con una perspectiva menos real.

El juego de realidad y ficción nos permite emplear elementos o situaciones improbables, mundos surrealistas y personajes vivientes.

\subsection{Story board y bocetos.}

El álbum está formado por 32 páginas e incluye:

-Portada y contraportada (2 páginas).

-Guardas iniciales (2 páginas).

-Créditos y portadilla (2 páginas).

-12 ilustraciones a doble página formadas por 2 ilustraciones dobles definitivas y 10 bocetos a doble página (24 páginas).

-Guardas finales (2 páginas).

Como indico anteriormente, tanto los bocetos como ilustraciones finales, están hechas a doble página.

Un storyboard o guión gráfico es según Hart (2008) 'un conjunto de ilustraciones mostradas en secuencia con el objetivo de servir de guía para entender una historia', es decir es una planificación grafica con una serie de bocetos a doble página que van acompañados de un texto y nos sirven para entender de qué va a tratar la historia posteriormente ilustrada. Este concepto se coge del lenguaje fílmico y se adapta a publicaciones de imagen fija.

Normalmente, de tamaño pequeño, aparecen en una misma página para así con un vistazo rápido, saber de qué va la historia. De esta manera se puede trabajar rápidamente tantas veces como sea necesario para proceder al diseño de las ilustraciones definitivas.

Esto ha sucedido en mi caso puesto que el Story inicial fue cambiando poco a poco hasta proceder a las ilustraciones y bocetos definitivos. Aunque la esencia 
de la historia persiste, es cierto que algunas ilustraciones tuvieron que ser modificadas para que la historia se entendiera mejor. Estas ilustraciones y bocetos definitivos se verán en el punto 6.6 Maquetación.

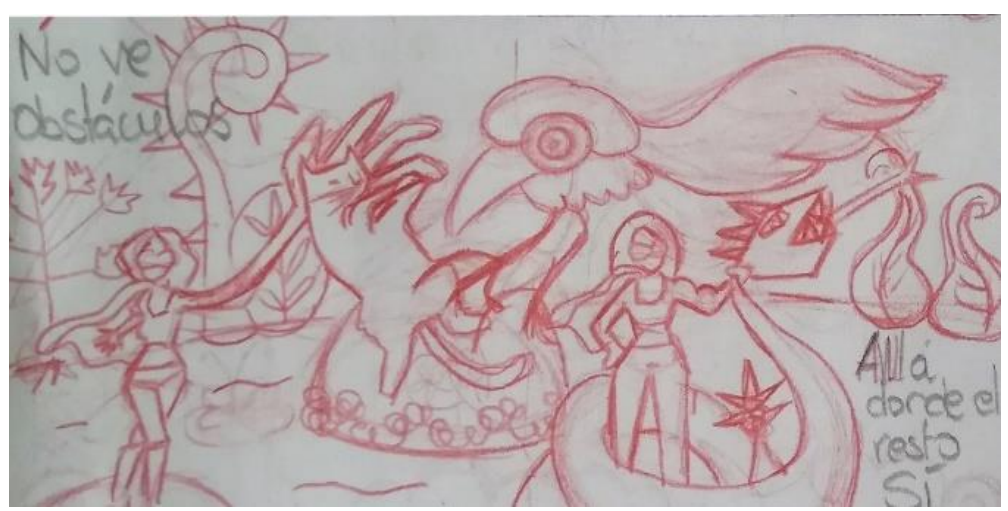

Ilustración 5: Propuesta inicial de la ilustración doble número 10, donde el gato en vez de caer del árbol, es agarrado por una especie de ave, y además la superheroína aparece desarrollando el atributo de la fuerza, atrapando una serpiente gigante. Fue cambiado por algo más cotidiano.

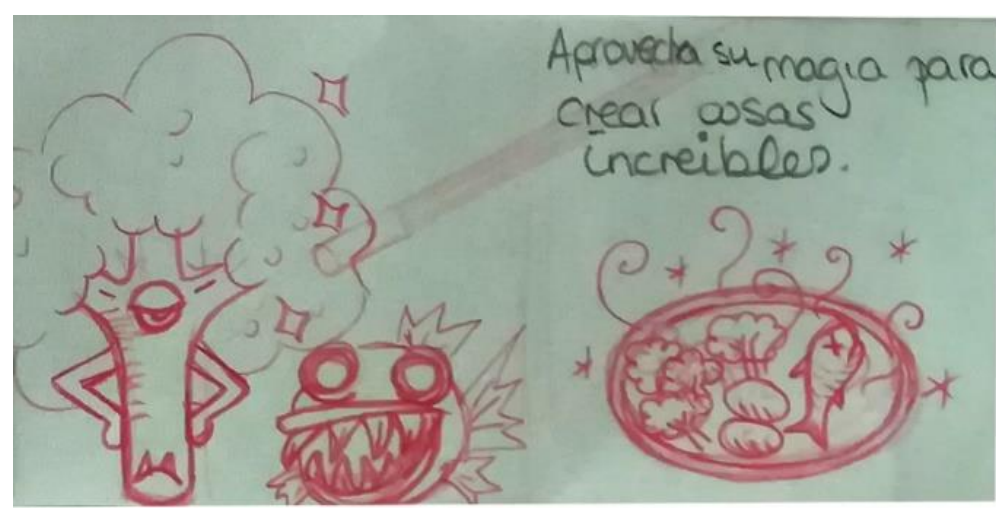

Ilustración 6: Propuesta inicial de la ilustración doble número 9, donde se ve algo que normalmente a los niños no les gusta como el brócoli y verduras, pero que la superheroína por arte de magia lo convierte en algo maravilloso. Esta ilustración es modificada para convertirla en un paisaje bonito lleno de comida como brócoli, setas o champiñones, lechuga, alcachofas...

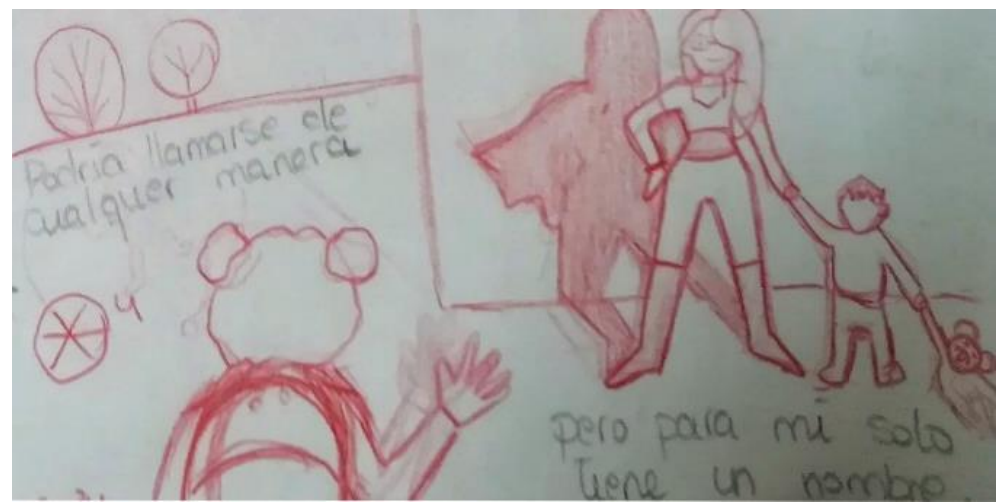

Ilustración 7: Propuesta inicial de la ilustración doble final, donde aparece la niña y la madre junto a su hijo y el osito de peluche. Fue modificado para que pudiera verse el rostro de la niña, como si la madre la recogiera del colegio. 


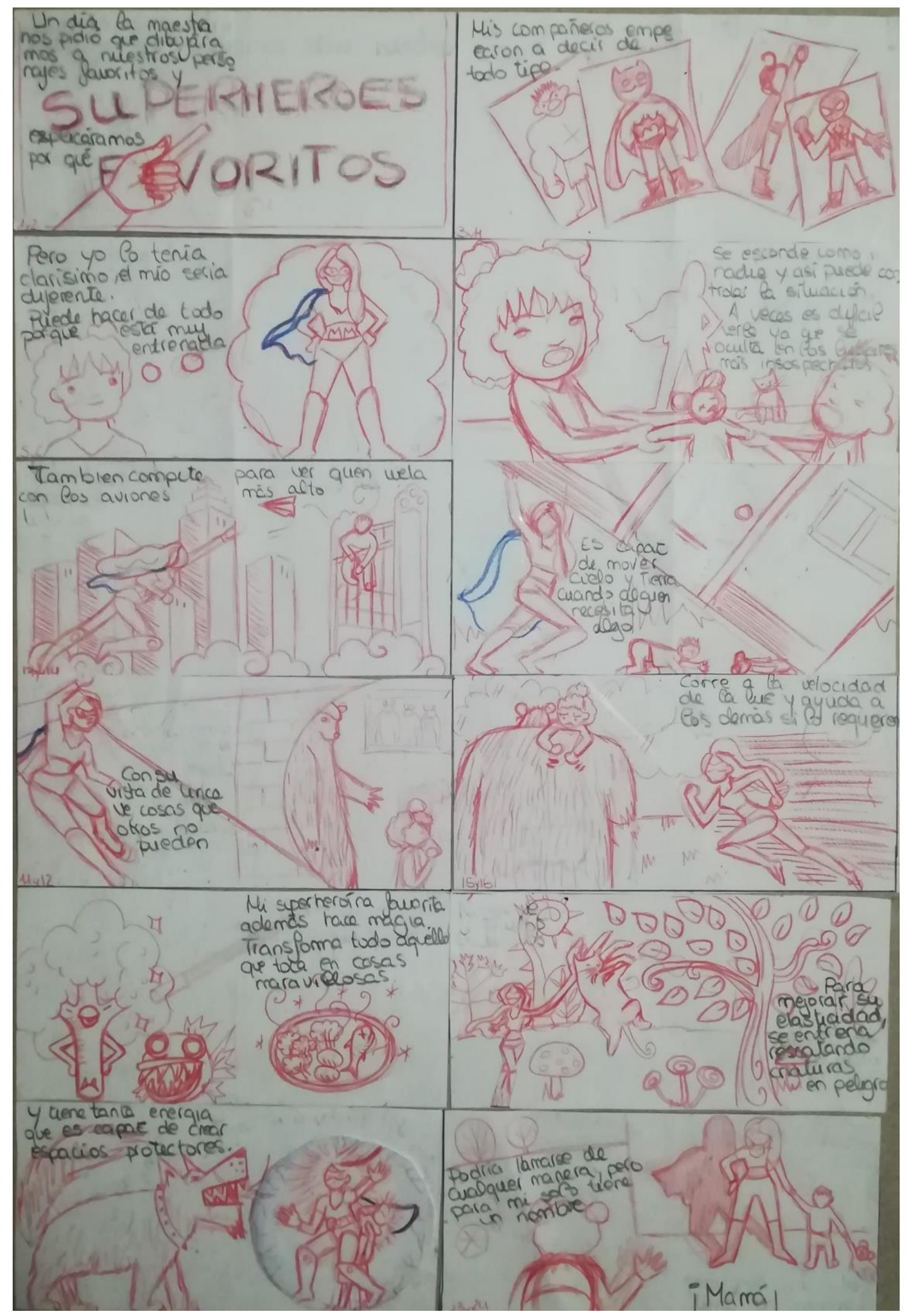

Ilustración 8: Storyboard 
El Storyboard se divide en varias partes, mezclando fantasía y realidad. La primera ilustración a doble página nos muestra una pizarra y la maestra dice que tienen que pensar en su superhéroes favorito. En la segunda, a modo de pose, se ven diferentes superhéroes aparentemente conocidos, que son aquellos que los compañeros de nuestra niña protagonista y narradora van diciendo.

En la tercera, la niña imagina su superheroína y a partir de aquí hasta la ilustración final, todo es fantasía en la imaginación de la niña.

La niña nos habla de cómo se entrena su superheroína, pero realmente casi todo está relacionado con momentos cotidianos como peleas con su hermano, comida que no suele gustar a los niños como brócoli y verduras, situaciones cuando se pierde algo, el niño que intenta salir de la cuna, miedo cuando su perro ladra, etc. Las imágenes suelen tener cierta relación, como es el caso del gato que aparece en la ilustración 4, es el mismo al que la heroína rescata después; el niño de la cuna es el que se pelea con la niña por el oso de peluche y a su vez el que después busca su osito de peluche; el oso del cuento de los tres cerditos podría hacer referencia al oso de peluche también.

Algunas ilustraciones y bocetos han sido modificadas con respecto a este storyboard. Las partes de fantasía en cuanto a las ilustraciones tienen un filtro que nos permiten diferenciarlas mejor de las partes reales. Además, los bocetos han sido acabados digitalmente para que sean lo más parecido a las ilustraciones.

Algunos de los atributos de la protagonista son por ejemplo el poder de ocultarse (invisibilidad), el de acudir donde sea cuando la gente está en apuros (volar), mover cielo y tierra si se necesita algo (fuerza), vista como un lince para ver lo que nadie puede (vista aguda), velocidad de la luz si alguien está en peligro (rapidez), transformar y crear cosas fantásticas (magia), o la capacidad de protección ante problemas (bola protectora a lo largo que quien realmente es esa mujer, es la madre de la protagonista.).

Este álbum nos cuenta como una niña ve a su madre y como situaciones simples en su cabeza puede ser algo caótico, sin embargo la madre es la única persona capaz de entender y anteponerse a esos miedos o problemas que puede surgirle a los más pequeños. Estos se sienten protegidos por sus más allegados, los cuales los ayudan a superar esos miedos para seguir adelante. 


\subsection{Ilustraciones definitivas, portada, contraportada y guardas.}

Estas son las dos ilustraciones definitivas (sin texto), creadas para la propuesta de álbum ilustrado de contrapunto.

En la primera se ve a la niña pensando en su superheroína favorita. Dicho pensamiento va en una textura y color diferente, puesto que nos sirve para diferenciar la realidad de la imaginación.

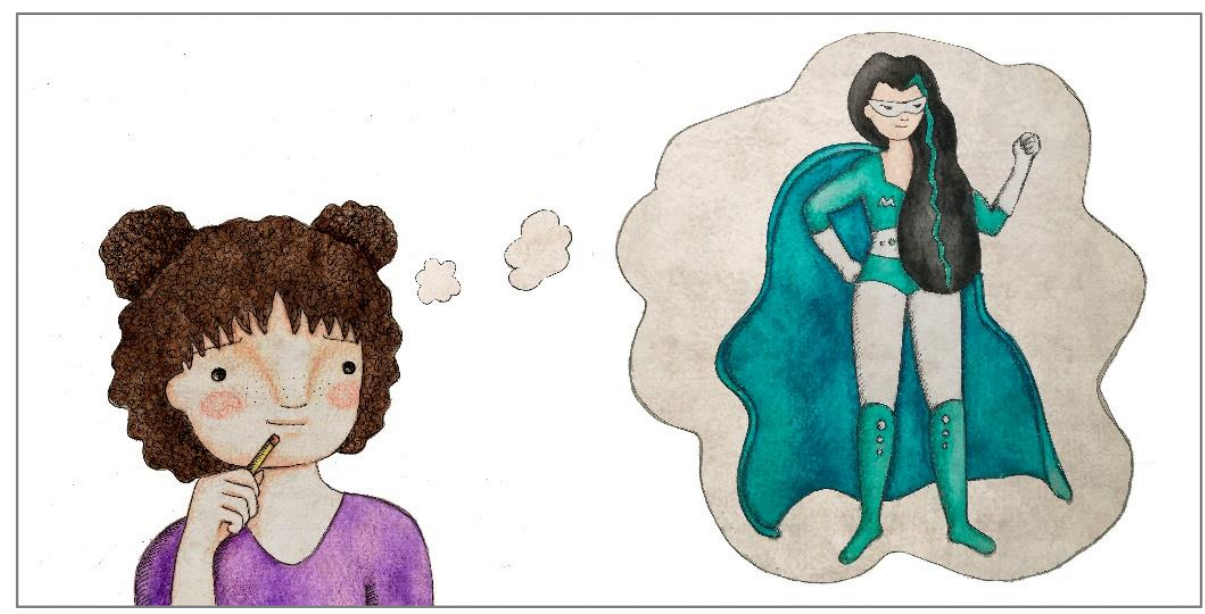

Ilustración 9: Ilustración definitiva de la propuesta de álbum ilustrado.

En la segunda, también con una textura y color más cálido, vemos a la superheroína "entrenándose" y rescatando al gato que ha caído del árbol y se siente amenazado por dos criaturas.

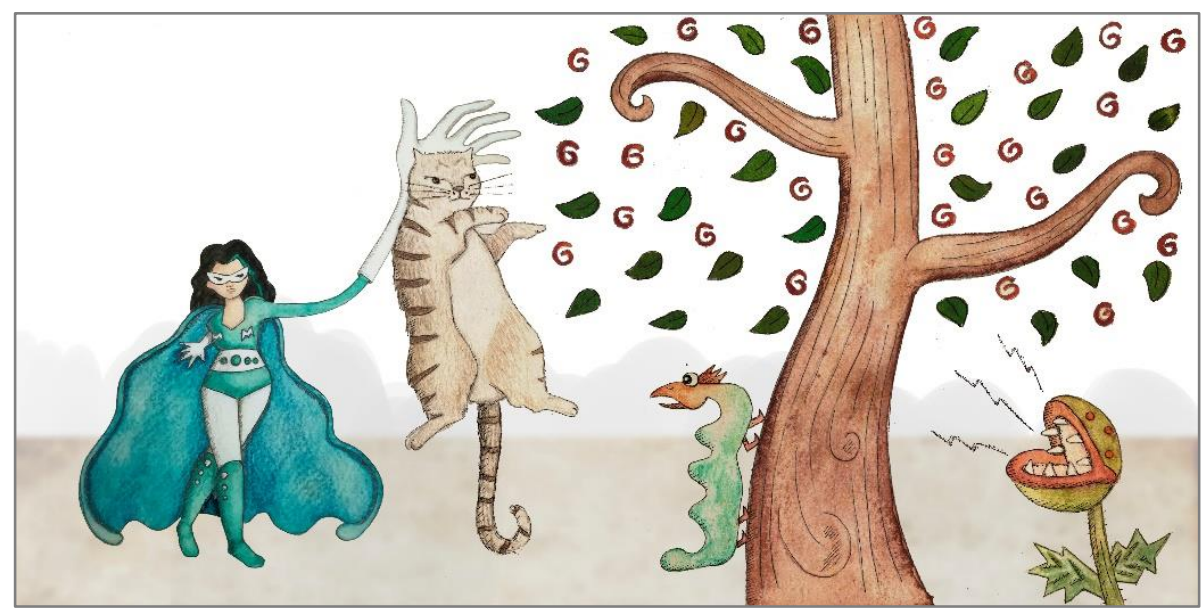

Ilustración 10: Ilustración definitiva de la propuesta de álbum ilustrado. 
Tanto la portada, como la portadilla, hacen referencia a elementos y acciones que aparecen en la historia. En la contraportada podemos ver la silueta de la superheroína volando, y en la portada, las criaturas que aparecen en la ilustración anterior. Las guardas son onomatopeyas referentes a acciones y voces de perros y gatos, y la portadilla nos muestra un 'monstruo"' que también aparece en la historia.

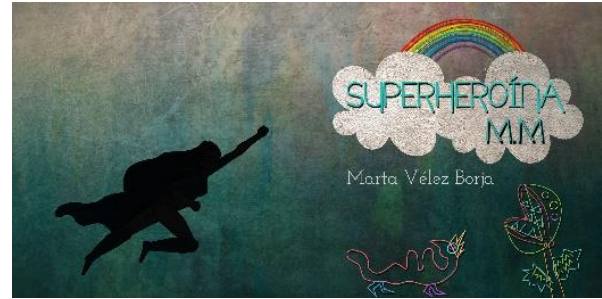

Ilustración 11: Contraportada y portada del álbum (ilustración doble).

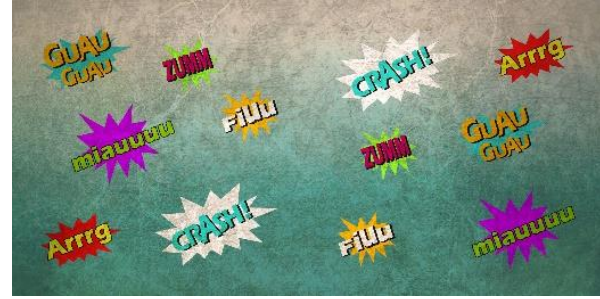

Ilustración 12: Guardas iniciales y finales de la propuesta de álbum ilustrado.

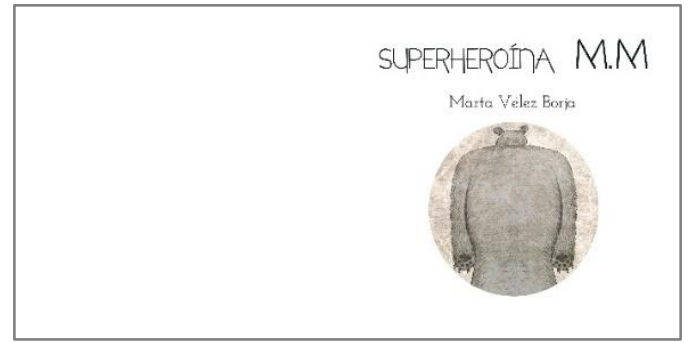

Ilustración 13: Portadilla de la propuesta de álbum ilustrado

\subsection{Técnica y acabado.}

La técnica empleada para cada boceto es grafito tanto negro como de color rojo.

Para las ilustraciones definitivas se ha usado grafito para bocetar, lápices de color acuarelables, toques de lápices de colores, rotring negro de 0,1 y acabado en digital.

El acabado digital consiste en poner textura a la ilustración de fantasía y añadir parte del fondo.

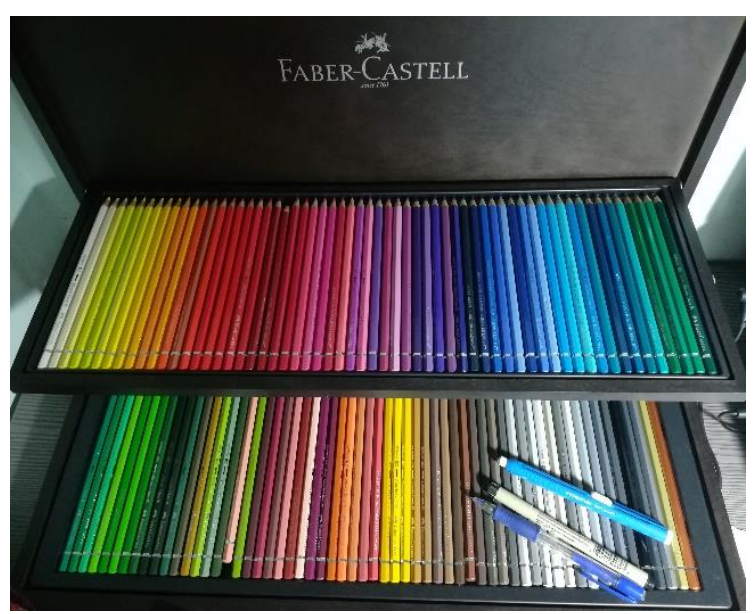

Fotografía 2: Técnica empleada. Lápices acuarelables, grafito y rotring 0,1 . 


\subsection{Maquetación y resultado final}

La maquetación de la propuesta de álbum de contrapunto creada, se ha realizado con el programa INDESIGN, donde se ponen las medidas y márgenes correspondientes, para después importar las imágenes a doble página y así poder añadir el texto. Se incorporan tanto la portada, guardas iniciales y finales, portadilla y contraportada, así como los bocetos e ilustraciones definitivas (las cuales están a color). La maqueta completa es la siguiente:

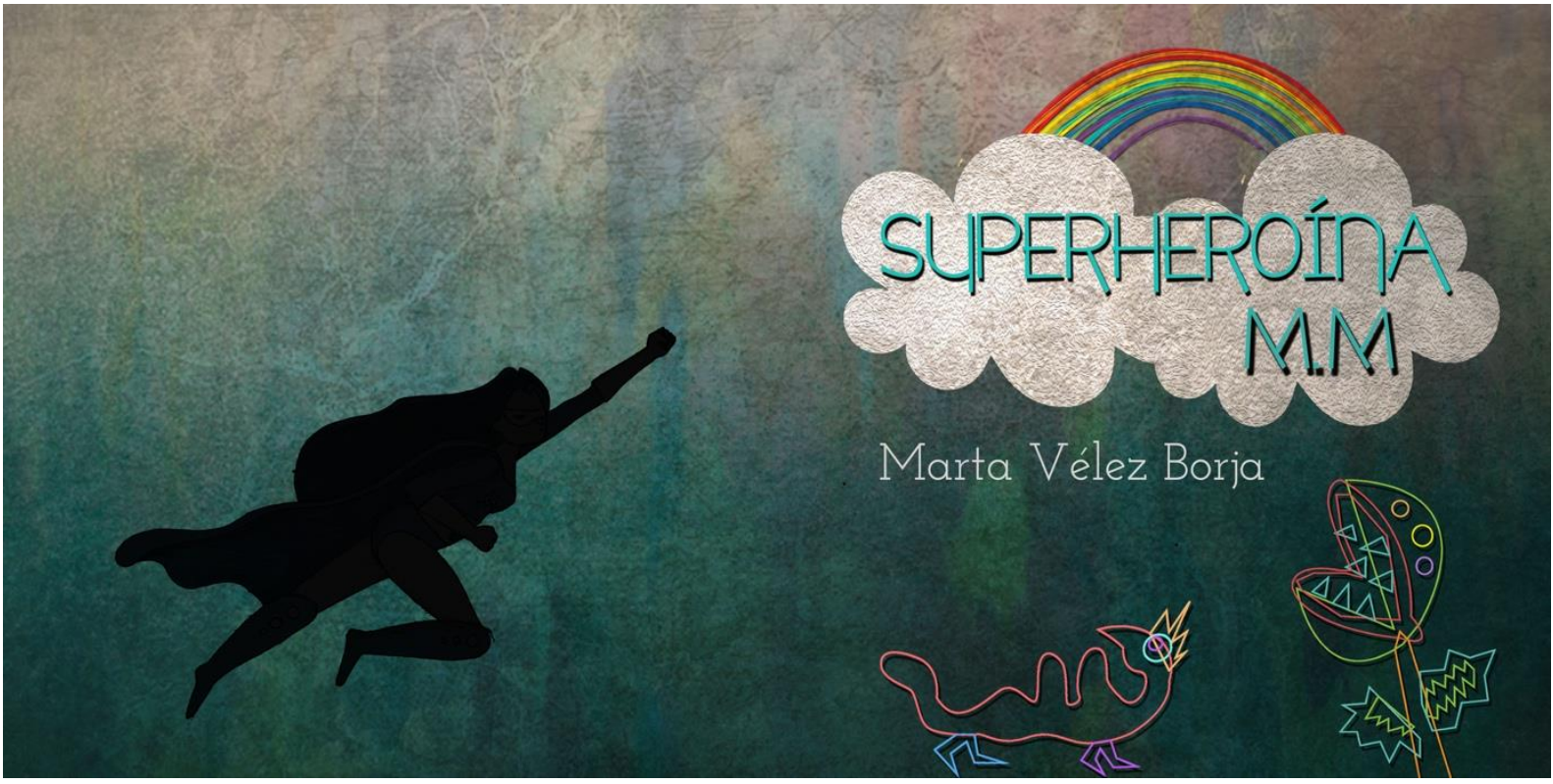

Ilustración 14: Contraportada y portada.

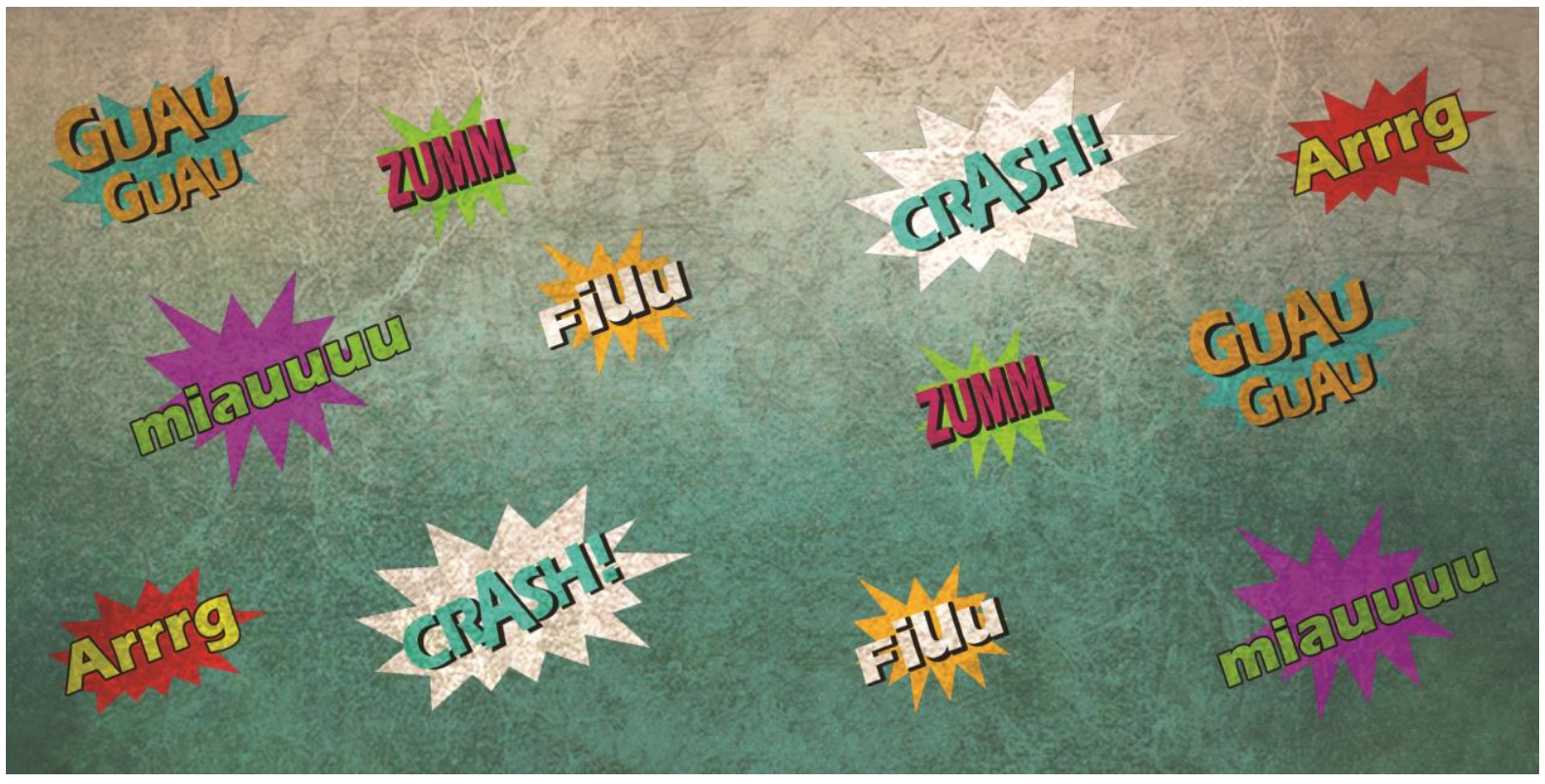

Ilustración 15: Guardas iniciales. 


\title{
SUPERHEROÍTA M.M
}

\author{
Marta Vélez Borja
}

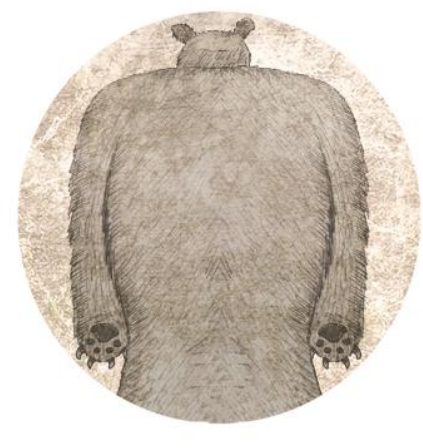

Ilustración 16: Portadilla.

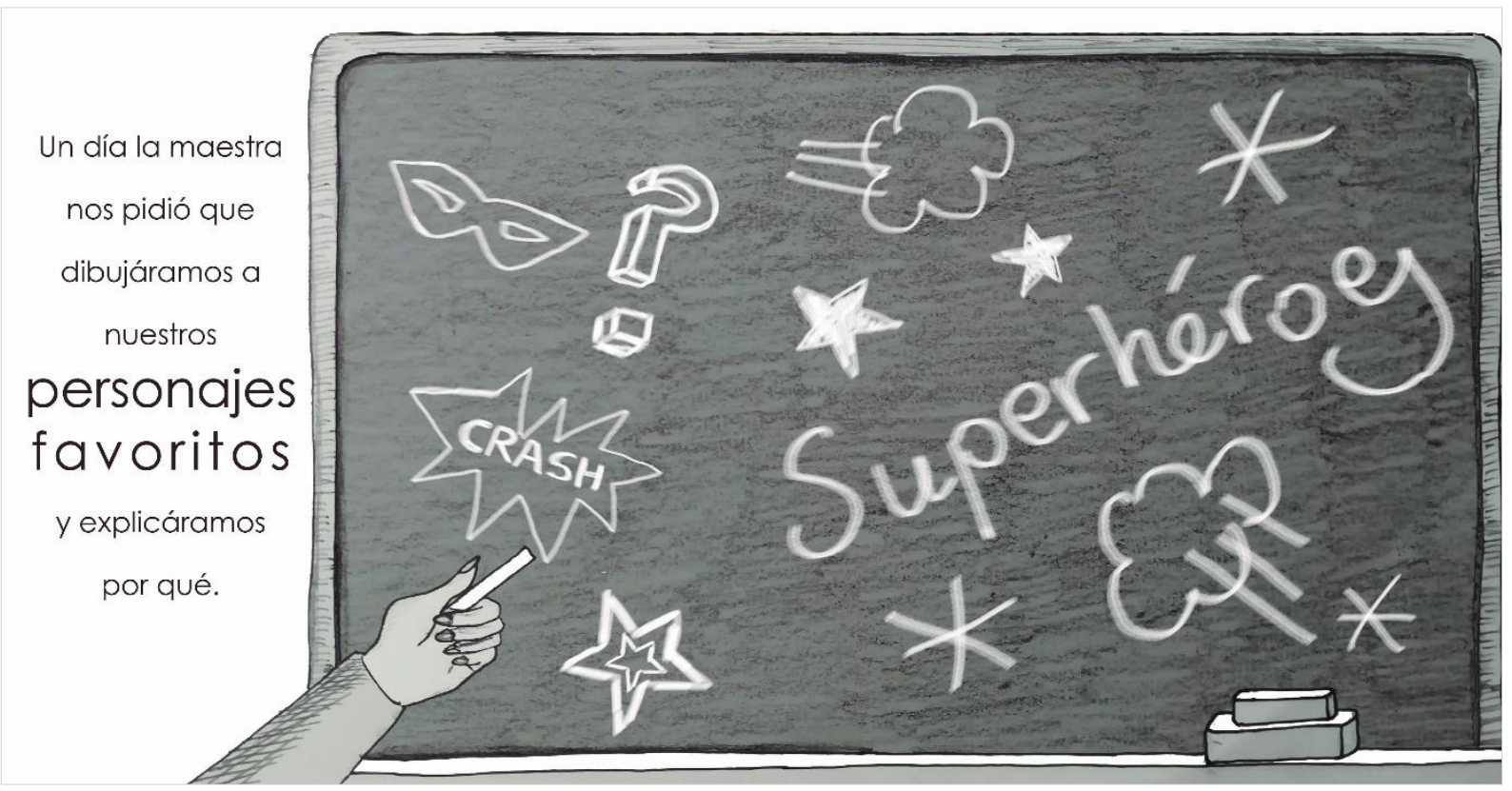

Ilustración 17: Bocetos pág. 1 y 2. 

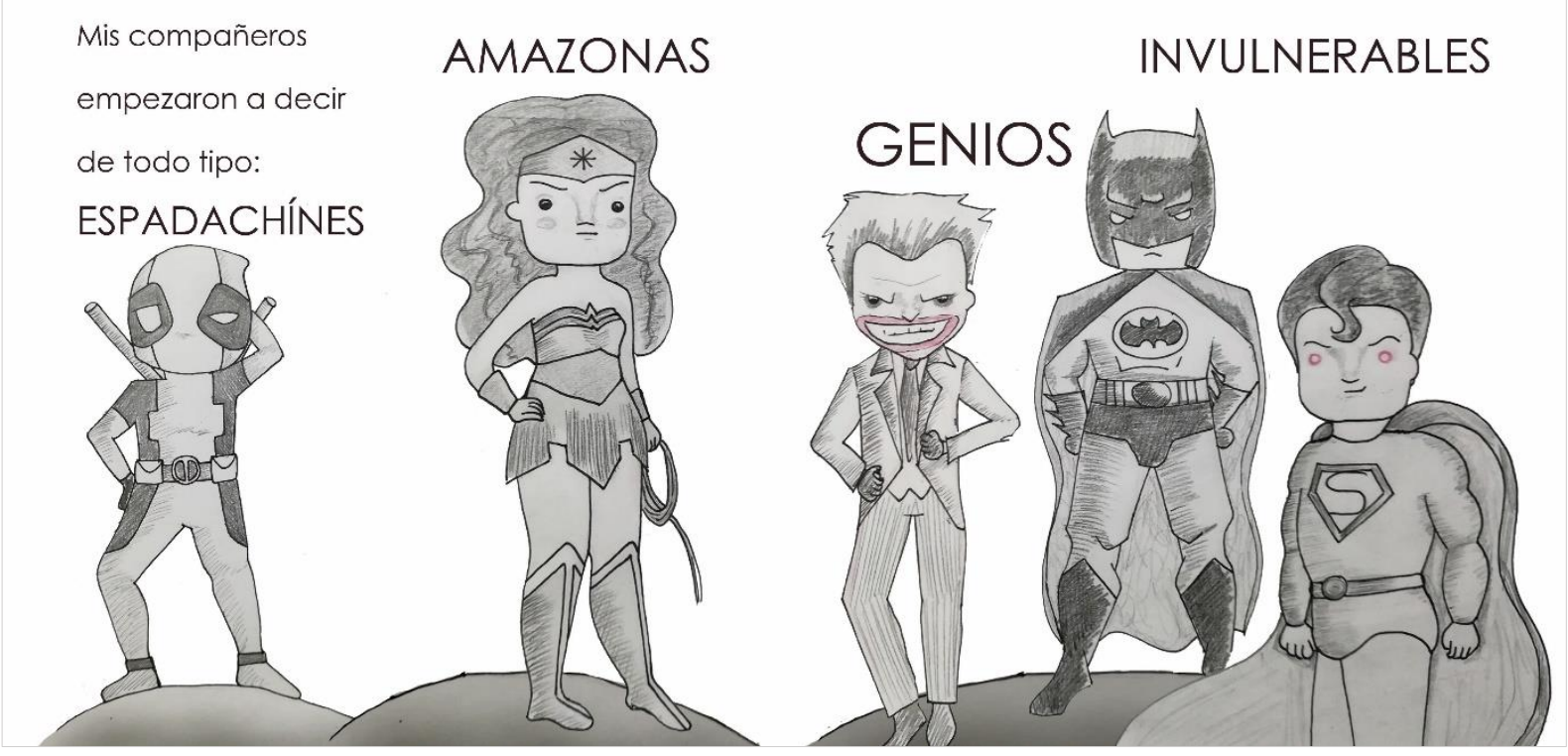

Ilustración 18: Bocetos pág. 3 y 4.

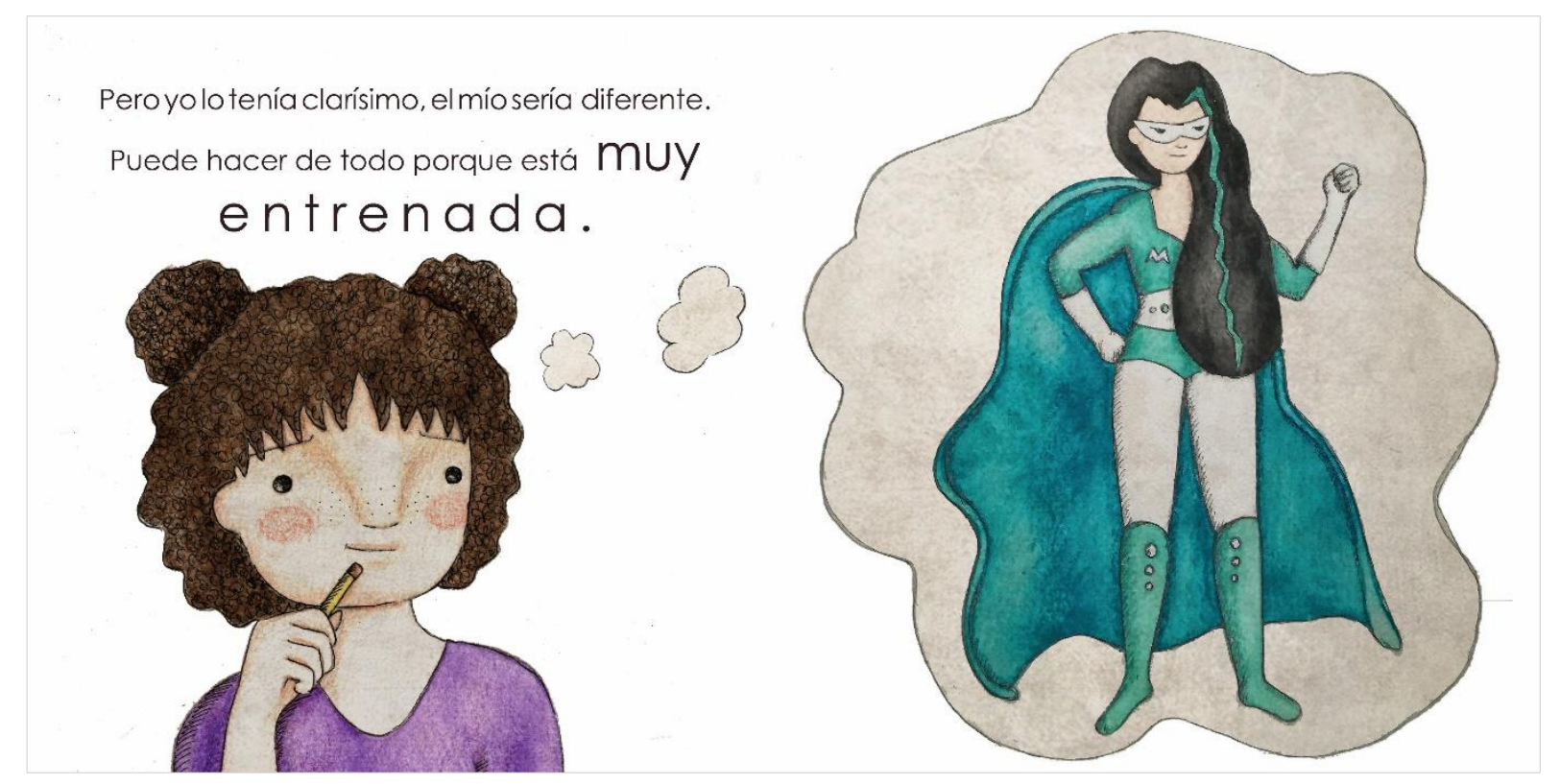

Ilustración 19: Ilustración definitiva, pág. 5 y 6. 


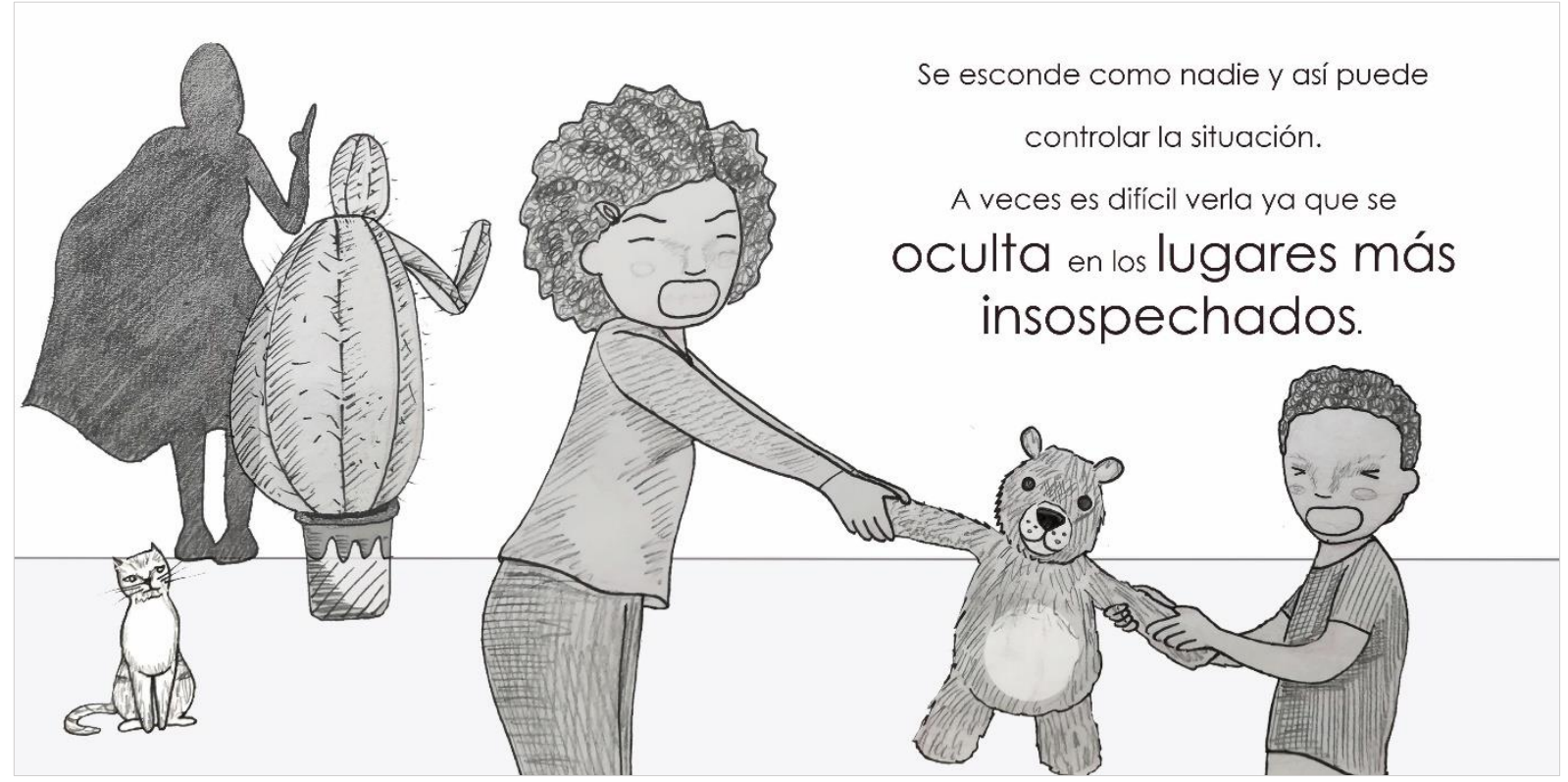

Ilustración 20: Bocetos pág. 7 y 8.

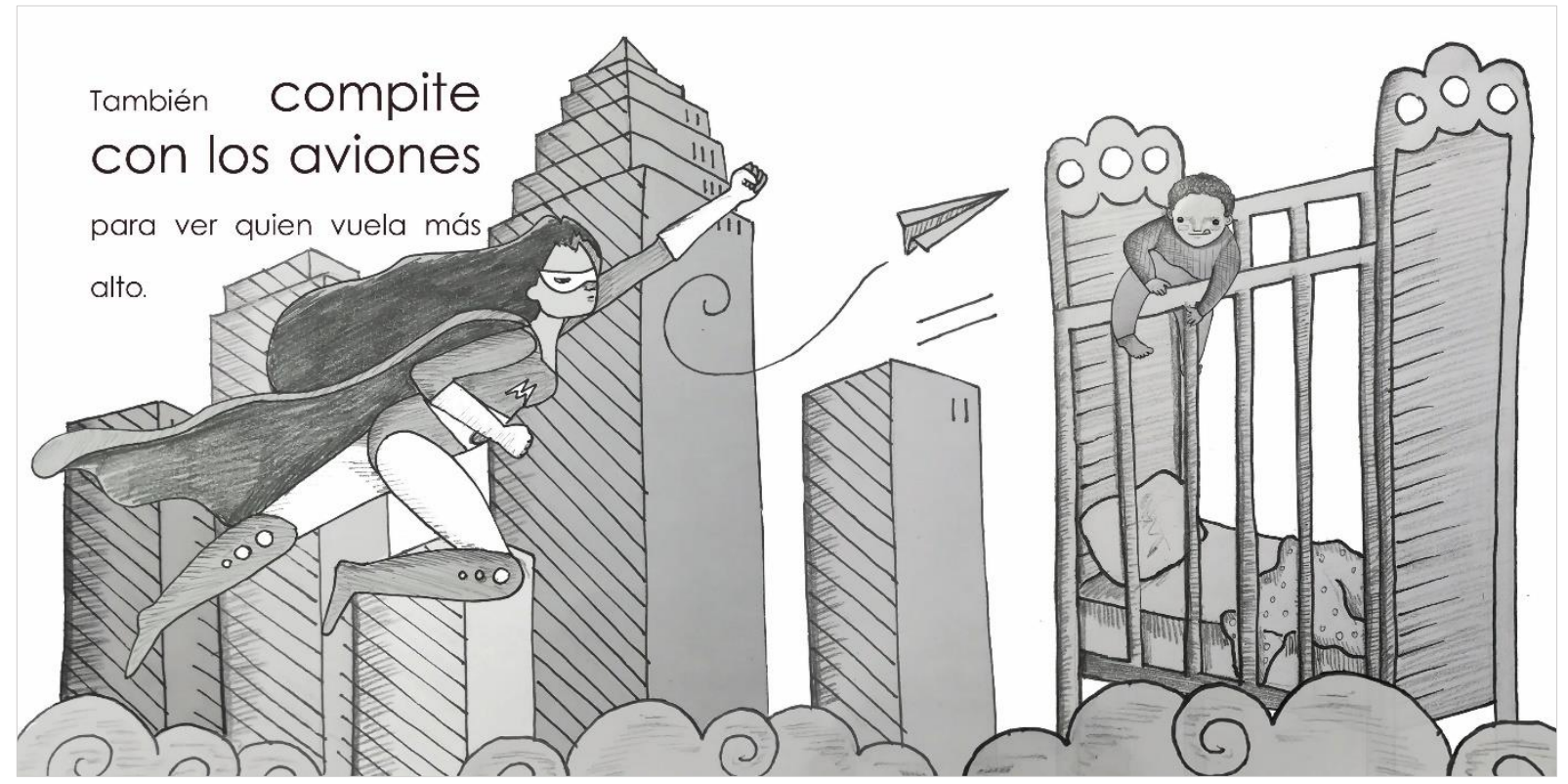

Ilustración 21: Bocetos pág. 9 y 10. 


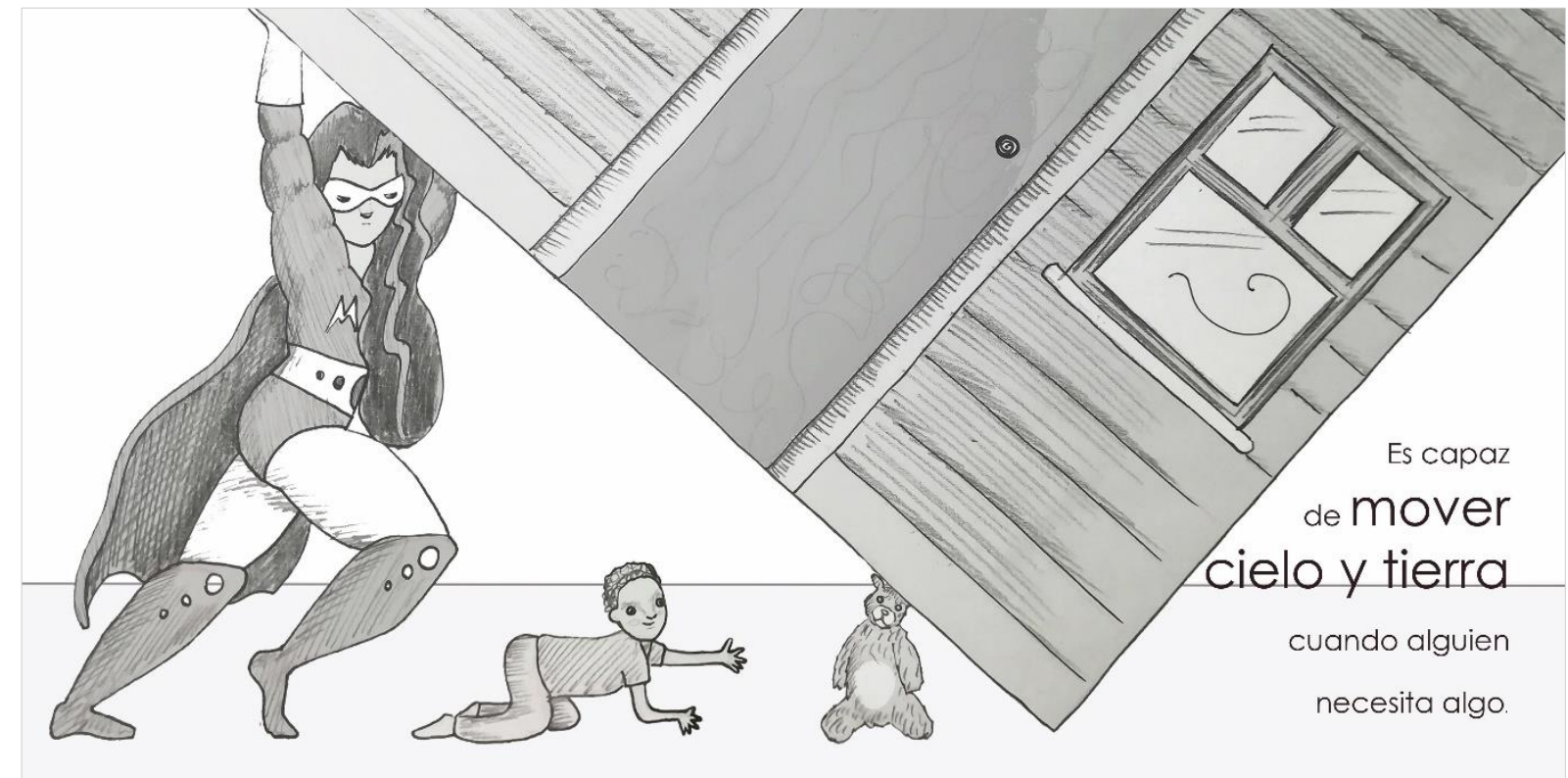

Ilustración 22: Bocetos pág. 11 y 12.

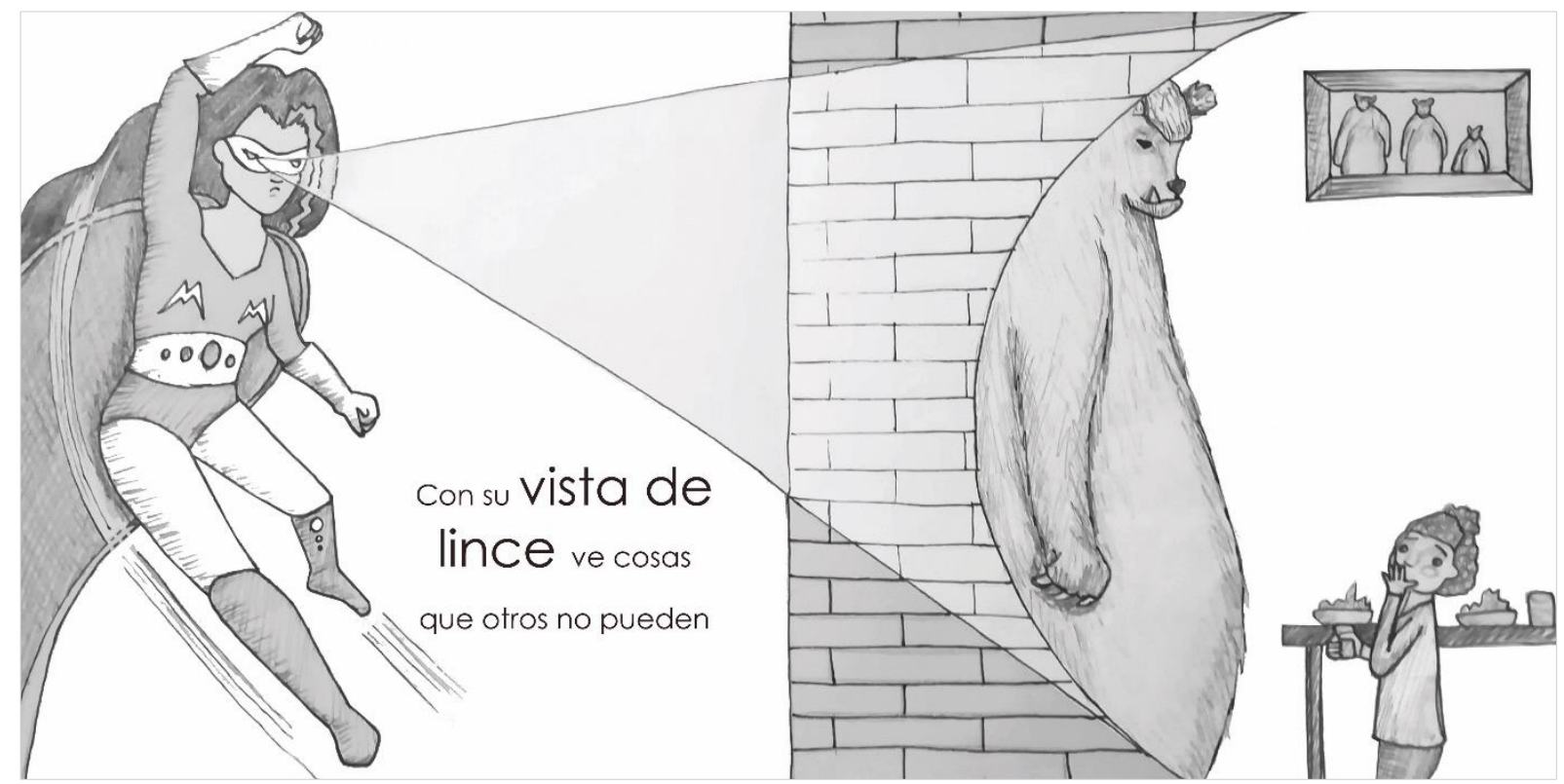

Ilustración 23: Bocetos pág. 13 y 14. 


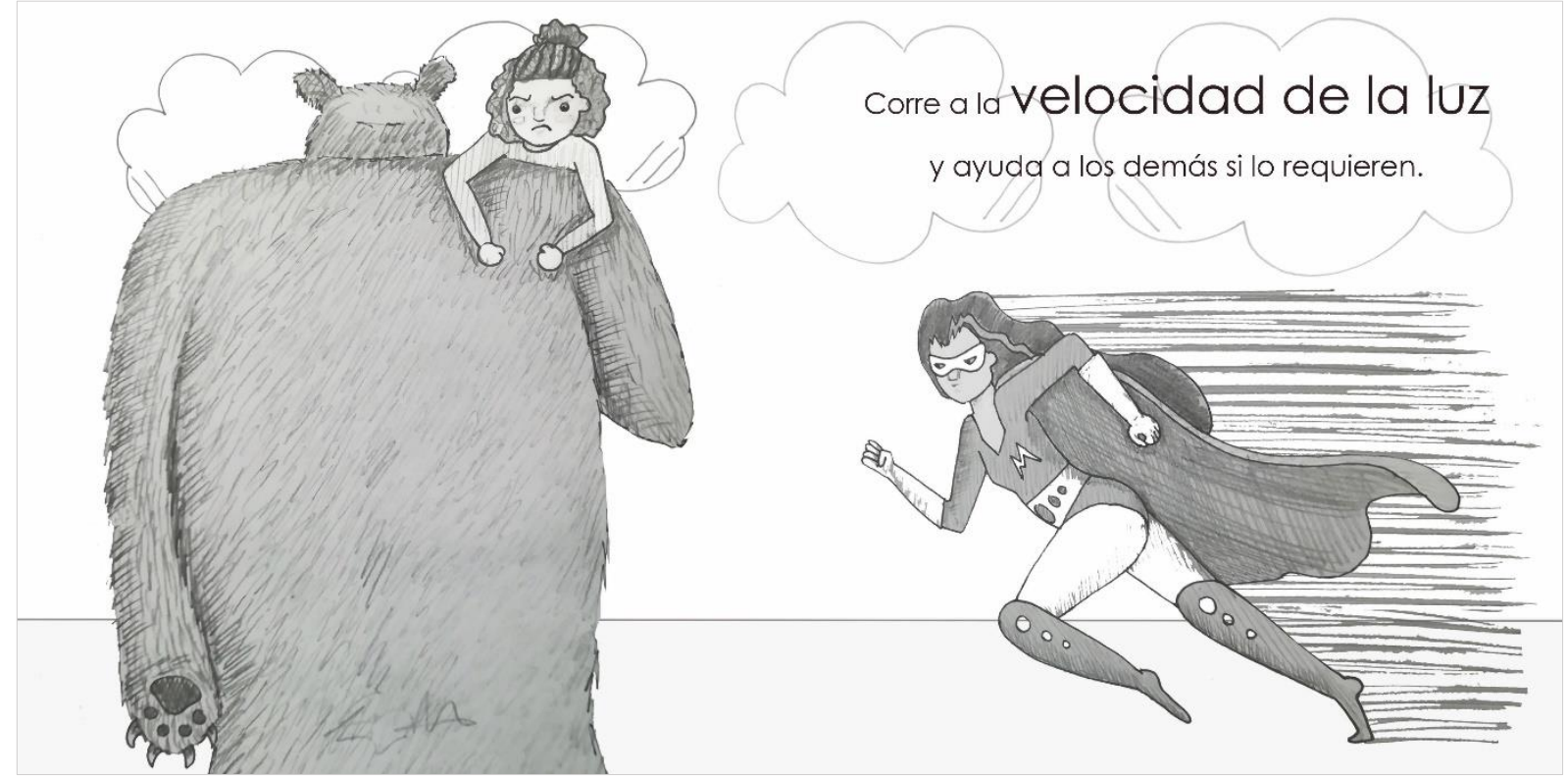

Ilustración 24: Bocetos pág. 15 y 16.

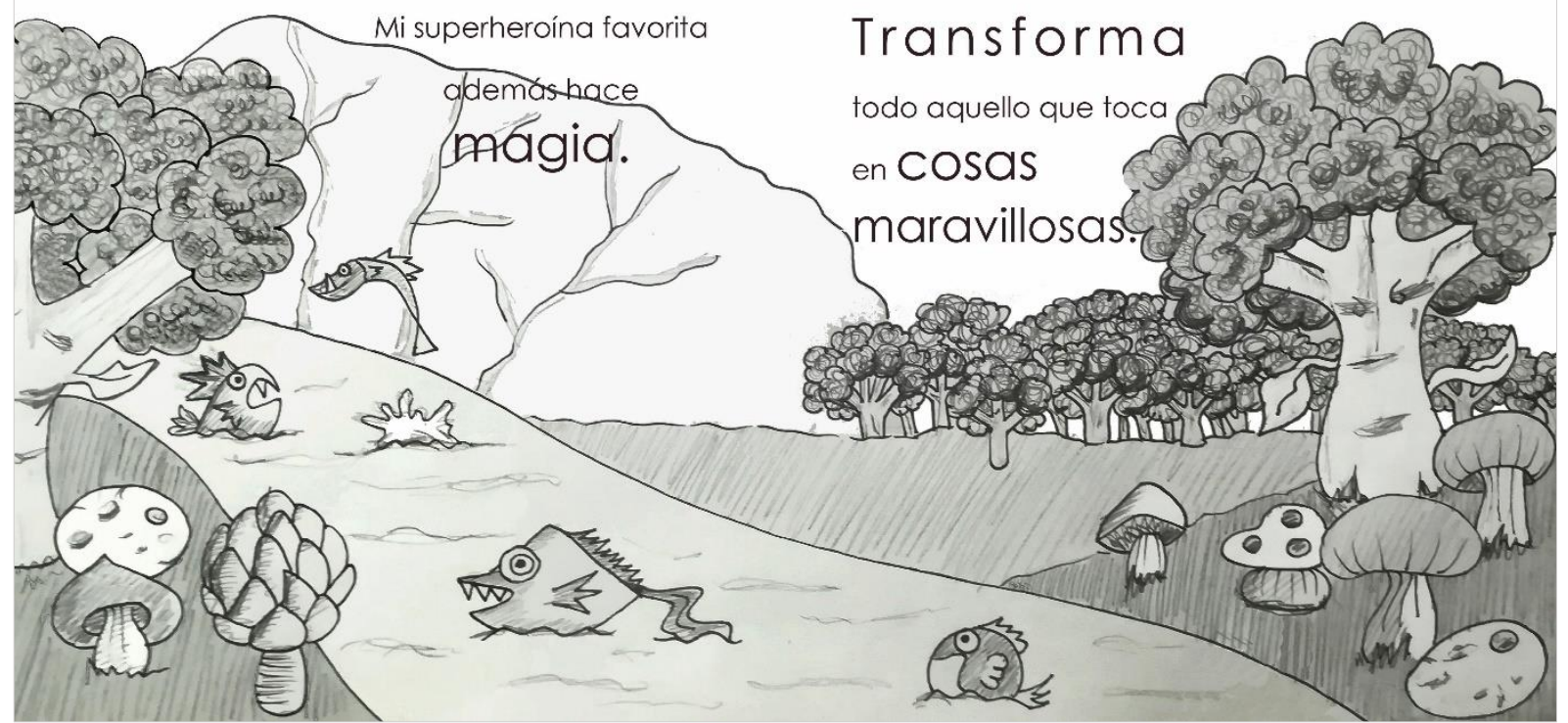

Ilustración 25: Bocetos pág. 17 y 18. 


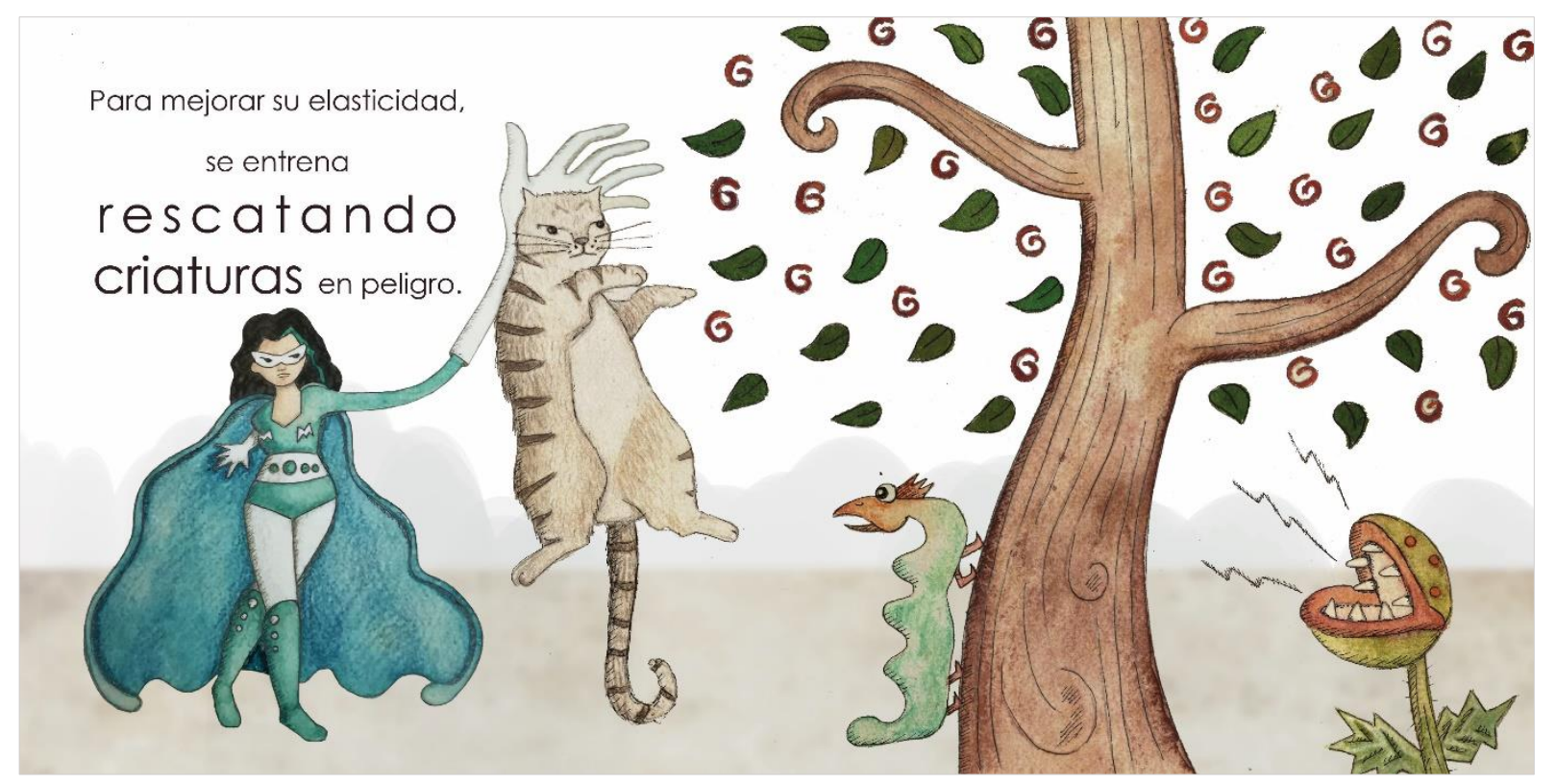

Ilustración 26: Ilustración definitiva pág. 19 y 20.

Y tiene tanta energía que es capaz de crear espacios protectores.
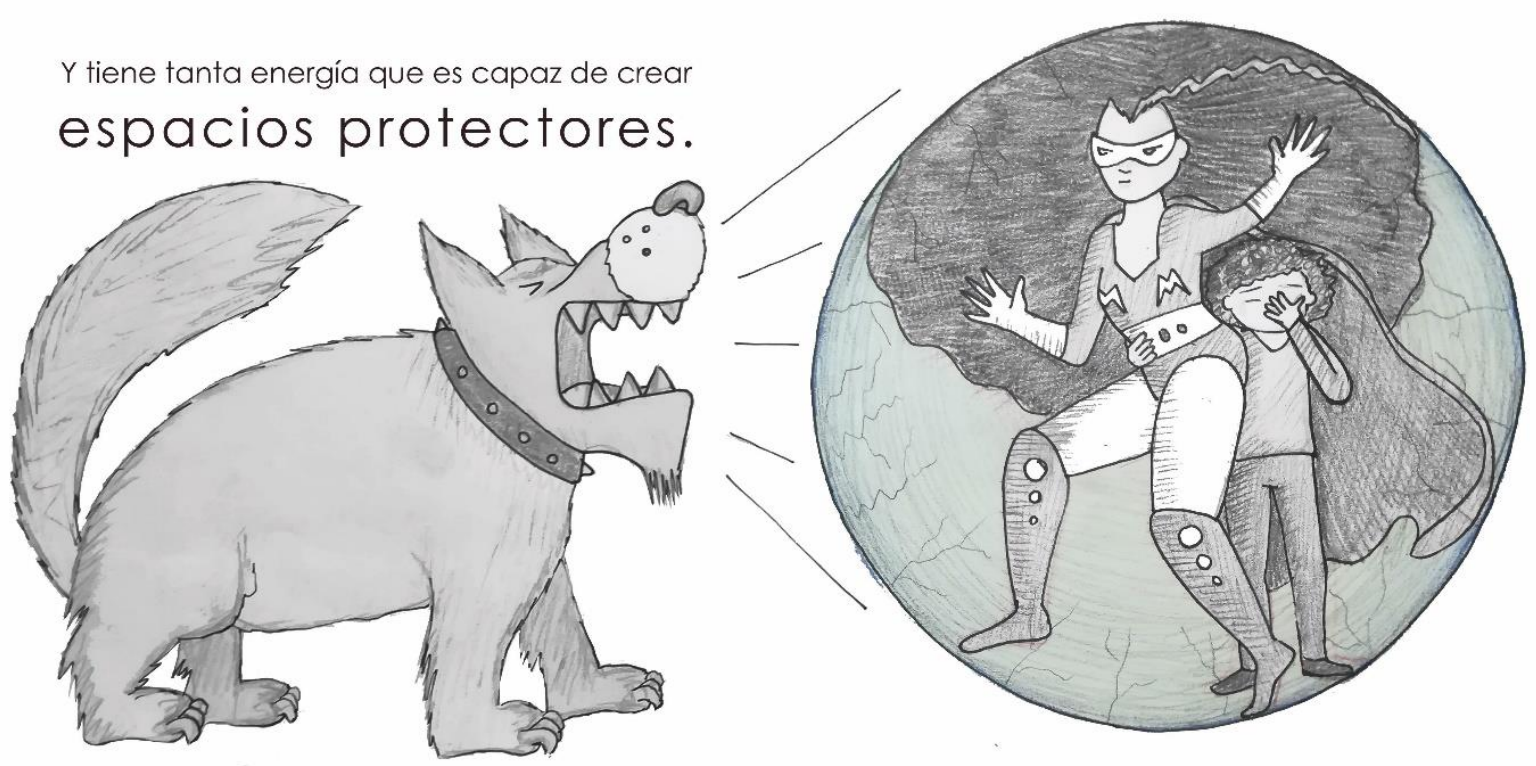

Ilustración 78: Bocetos pág. 21 y 22. 


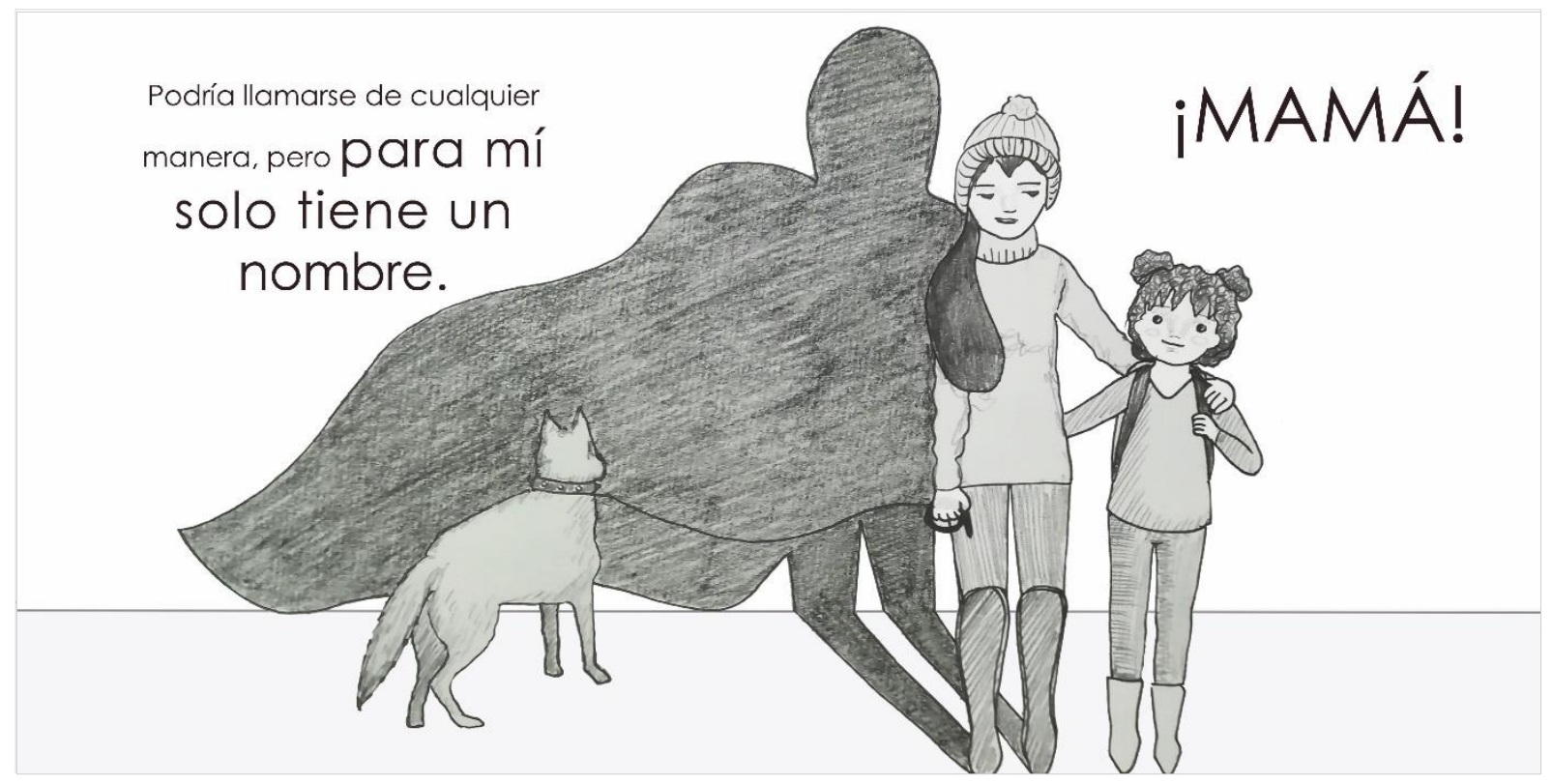

Ilustración 28: Bocetos pág. 23 y 24.

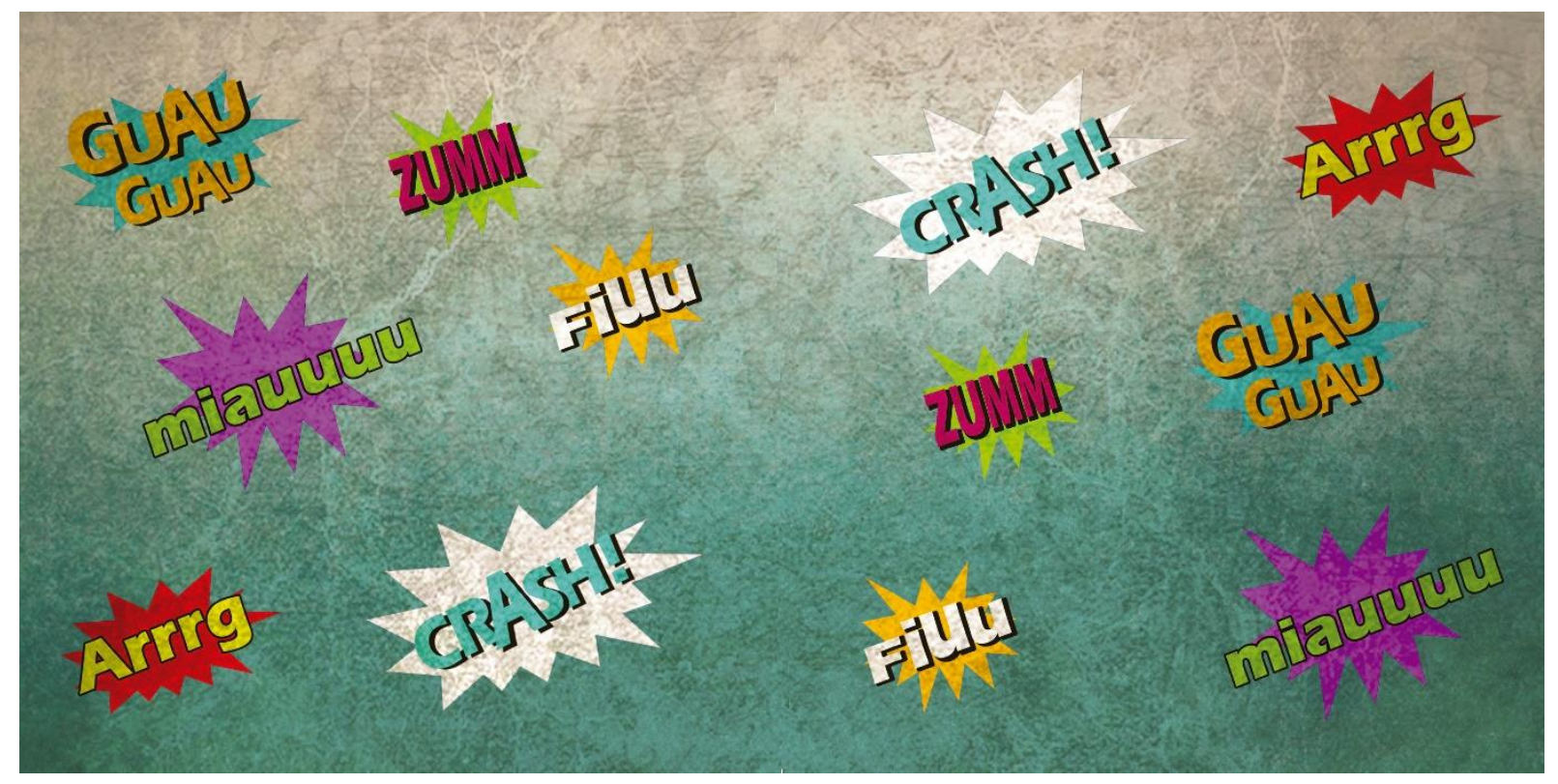

Ilustración 29: Guardas finales. 


\section{CONCLUSIONES}

El trabajo se centra en dos partes concretas: la relación que existe entre texto e imagen en los álbumes ilustrados infantiles de contrapunto, y la creación de un proyecto sobre un álbum ilustrado propio, donde se ponen en práctica los conocimientos adquiridos.

Para conseguir los objetivos del trabajo era necesario en primer lugar buscar información sobre esta clase de libros, sin embargo, me di cuenta de que aunque el álbum ilustrado en sí es muy abundante en bibliotecas y librerías especializadas, no sucede lo mismo con los álbumes infantiles de contrapunto. Aunque son una minoría de libros o artículos los que hablan concretamente sobre este tipo de álbumes, en ellos encontramos información valiosa que nos ayuda a comprender mejor cómo funcionan.

En cuanto al análisis de los catorce álbumes seleccionados, he de decir que poder encontrarlos no me resultó fácil y mucho menos si nos referimos a autores españoles. Es cierto que las editoriales españolas trabajan con este tipo de álbumes, sin embargo no existe gran cantidad de autores o ilustradores españoles que creen álbumes de contrapunto. Generalmente los álbumes elegidos son entendibles para los niños, aunque, en alguno de los casos son bastante complejos, incluso para los adultos.

Los resultados de dichos análisis concretan que la imaginación y ficción juega un papel importante en las ilustraciones de la inmensa mayoría de los álbumes examinados, por lo que de nuevo podemos concluir con que los álbumes ilustrados son una herramienta importante para el desarrollo de la creatividad asi como madurez para interpretar.

Por otra parte, los álbumes elegidos suelen dividirse casi por igualdad entre álbumes con una historia contradictoria bien mediante ironía o humor, y una alternativa donde las ilustraciones nos muestran diferentes historias que suceden a la vez. En cuanto a los tipos de final, la mayor parte de los álbumes analizados que tienen un final que admite una única posibilidad, a su vez suelen hacer referencia al inicio de la historia. 
Todo lo anterior es referente a la parte teórica, sin embargo en cuanto a la creación plástica, la intención principal era la de diseñar un proyecto de álbum ilustrado de contrapunto que nos pudiera servir como recurso creativo y didáctico en una aplicación posterior, puesto que en este trabajo ha sido complicado por falta de tiempo.

La experiencia de poder diseñar un álbum ilustrado ha sido muy positiva a nivel personal, puesto que hace que desarrolles la imaginación, y más aún para crear una historia de contrapunto donde el texto te dice una cosa y las imágenes otra. Como dije anteriormente, esta clase de libros no son tan comunes (y mucho menos antes, cuando yo era niña), por lo que no estamos habituados a ellos, sin embargo, aunque la lectura no sea siempre complicada (como sucede en Granpa (2003) y Odio a mi osito de peluche (2005)), la creación y combinación de texto e imagen que vaya más allá del complemento de ambos medios, es un tanto complicada.

El hecho de poder haber introducido esta historia y haber jugado con la ficción, me ha dado la absoluta libertad de poder crear algo fuera de lo real y a lo que yo no estoy acostumbrada a dibujar. Además, el tema de como una niña ve a su madre y como se refleja en la historia, me parece interesante. En cierto modo me veo identificada con esa niña y por eso he creado esta historia con tanto cariño.

Lo más complicado a mi parecer fue la creación del texto ya que debía hacer referencia en parte a lo que muestran las imágenes, pero reflejando otra perspectiva.

En cuanto a los bocetos, he decidido que tuvieran un acabado digital con el fin de que se pudiera interpretar mejor la historia y fueran lo más parecido a las ilustraciones finales.

En definitiva me ha gustado formar parte de esta investigación puesto que hasta hace poco no conocía este tipo de álbumes y creo que son de los más completos a la hora de desarrollar la mente lectora, por lo que son un buen medio de comunicación y de interpretación, especialmente para los niños. 


\section{REFERENCIAS Y BIBLIOGRAFÍA}

\subsection{Publicaciones}

- Chiuminatto Orrego, M. (2011). Relaciones texto-imagen en el libro álbum. Revista Universum, 26 (1), 59-77.

- Donis, D. A. (1988). La sintaxis de la imagen. Barcelona: Gustavo Gili.

- Flores Redondo, R. (2015). El álbum ilustrado como transmisor de valores en la infancia. Diseño y creación de un álbum comprometido. (Trabajo fin de máster). Universidad de Bellas Artes, Granada, España.

- Gombrich, E. H. (1979). Arte e ilusión. Barcelona: Gustavo Gili.

- Hart, J. (2007). The art of storyboard: A Filmmaker's Introduction. Burlington, MA: Focal Press.

- Hassett, D. D. y Scott Curwood, J. (2009). Theories and Practices of Multimodal Education: The Instructional Dynamics of Picture Books and Primary Classrooms. The Reading Teacher,63(4), 270-282.

- Hidalgo Rodríguez, M. C. (2015). The interaction between text and image in picturebooks. Analysis of story books published in spain today. The International Journal of Visual Design, 9, 1-14.

- Kress, G. (2010). Multimodality: a social semiotic approach to contemporary communication. Abingdon: Routledge.

- Kress, G. y Van Leeuwen, T. (1996). Reading images. The grammar of visual design. London: Routledge.

- Madrid, D \& McLaren, N. (2004). Telf in primary education. Granada: Granada University.

- Marín, R. (2005). Investigación en educación artística: Temas, métodos y técnicas de indagación sobre el aprendizaje y la enseñanza de las artes visuales. En Marín, R. (ed), La investigación educativa basada en las artes visuales o arte investigación educativa (pp.223-274). Granada: Universidad de Granada. 
- Moya Guijarro, A. J. y Pinar, M.J. (2007). La interacción texto /imagen en el cuento ilustrado. Un análisis multimodal. Revista OCNO S nº 3, 2007, p. 2138. ISSN 1885-446X .

- Nikolajeva, M. y Scott, C. (2006). How Picture books Work. New York: Routledge.

- Nodelman, Perry. (1988). Words about pictures: the narrative art of children's picture books. University of Georgia Press, Athens, Georgia.

- Salisbury, M. (2004). Ilustración de libros infantiles: Cómo crear imágenes para su publicación. Barcelona: Editorial Acanto, S.A.

- Salisbury, M. y Styles, M. (2012). El arte de ilustrar libros infantiles. Barcelona: Art Blume, S.L.

- Senís Fernández, J. (2014). El albúm ilustrado como agente de educación artístico-literaria y de género el caso de Mamá, de Mariana Ruíz Johnson. Dossiers feministes, ISSN 1139-1219, $\mathrm{n}^{\mathbf{0}}$ 19, (ejemplar dedicado a: arte, educación y género), págs. 115-133.

- Schwarcz, J. (1982). Ways of the illustrator. Visual communication in Children's Literature. Chicago and London: American Library Association.

- Vélez Borja, M. (2015). Introducing the picture book The Lost Thing in a primary classroom. (Trabajo fin de grado). Universidad de educación, Granada, España.

\subsection{Referencias en la Web}

- Anaya editorial. Recuperado de https://www.grupoanaya.es/

- Blackie Books S.L.U. editorial. Recuperado de https://www.blackiebooks.org/

- Kalandraka editorial. Recuperado de http://www.kalandraka.com/

- Libros del Zorro Rojo editorial. Recuperado de http://librosdelzorrorojo.bigcartel.com/

- Picarona editorial. Recuperado de https://www.picarona.net/

- Thule ediciones. Recuperado de http://www.thuleediciones.com/ 


\section{3 Álbumes ilustrados}

-Altés, M. (2017). ¡No!. Barcelona: Ed. Thule.

- Altés, M. (2017). Soy un artista. Barcelona; Ed. Blackie Books S.L.U.

- Bruno, P. y Cabassa, M. (2010). La familia C. Vigo: Ed. Kalandraka.

- Burningham, J. (2003). Granpa. London: Ed. Red fox.

- Burningham, J. (2001). Hushabye. United States: Ed. Alfred A. Knopf. Recuperado de https://archive.org/details/hushabye00john

- Cole, B. (1998). La princesa Listilla. Barcelona: Ed. Destino, S.A. Recuperado de https://archive.org/details/miscellaneouschi00babe

- Cole, B. (1984). The trouble with mum. New York: Ed. Coward-McCann. https://archive.org/details/troublewithmom00cole

- Gravett, E. (2014). El gato de Matilda. Barcelona: Ed. Picarona (ediciones Obelisco, S.L.).

- Hughes, E. (2014). Salvaje.Barcelona: Ed. Libros del Zorro Rojo.

- Hutchins, P. (2015). Rosie's walk. New York: Ed. Little Simon.

- Kitamura, S. (1991). Lily takes a walk. New York: Ed. Dutton children's book.

- Lööf, J. (1987). La historia de una manzana roja. Valladolid: Ed. Miñón. Recuperado de https://archive.org/details/historiadeunaman001

- McKee, D. (2005). Odio a mi osito de peluche. Madrid: Ed. Anaya.

- Tan, S. (2007). La cosa perdida. Jerez de la Frontera, España: Bárbara Fiore Editora.

- Tan, S. (2012). The Lost Thing. Australia: Ed. A Lothian Children's Book.

- Toro, G. y Ferrer, I. (2007). Una casa para el abuelo. Madrid: Ed. Sins entido.

- Voltz, C. (2003). ¿Todavía nada?. Pontevedra: Ed. Kalandraka. 


\section{ANEXOS}

\section{ANEXO 1: ÁLBUMES ILUSTRADOS ANALIZADOS.}

\section{Una casa para el abuelo}

\section{DATOS TEÓRICOS}

De Grassa Toro e Isidro Ferrer (2007). Ed. Sins entido, Madrid. (Biblioteca Ugr de Bellas Artes)

-1º PUBLICACIÓN: Une maison pour grand-père .(2001). Ed. Thierry Magnier, Paris.

-RESUMEN: La historia habla sobre una familia que busca un lugar concreto para enterrar al abuelo. Una vez encontrado, lo entierran y deciden construir una casa justo encima para poder vivir todos juntos. Por las noches la abuela cuenta historias y acaba con la historia del barco.

\section{RELACIÓN TEXTO/ IMAGEN}

\begin{tabular}{l|l}
$\begin{array}{l}\text { LO QUE CUENTA EL } \\
\text { TEXTO }\end{array}$ & $\begin{array}{l}\text { Una familia entierra al abuelo y construyen una casa justo encima para vivir todos juntos. La } \\
\text { abuela cuenta historias por las noches pero siempre que cuenta la del barco, le sale voz de } \\
\text { hombre. El texto es sencillo normalmente aparece en una de las páginas dobles, salvo en dos } \\
\text { ocasiones donde no hay texto, pero si imagen como cuando se ve a la abuela contando } \\
\text { historias, o en el final, donde aparecen los dos ancianos en un barco. }\end{array}$ \\
\hline $\begin{array}{l}\text { LO QUE CUENTA LA } \\
\text { IMAGEN }\end{array}$ & $\begin{array}{l}\text { Una familia va caminado (les sigue un hombre, el cual posteriormente veremos que es el } \\
\text { abuelo), hay un lugar con casas y empiezan a cavar en la tierra. El abuelo aparece enterrado, } \\
\text { sin embargo parece estar vivo, mientras la familia encima construye una casa. Todos parecen } \\
\text { vivir en el mismo lugar (incluido el abuelo dentro de su "hoyo"). La abuela cuenta historias, a } \\
\text { la vez que el abuelo se comunica con ella. Finalmente los dos se van en un barco. }\end{array}$
\end{tabular}

\section{LO QUE NOS DICE LA HISTORIA EN CUANTO A TEXTO E IMAGEN EN SU CONJUNTO:}

La historia nos habla de la familia y de la muerte (el abuelo es enterrado, por lo que se supone que ha muerto). La familia se mantiene unida y acompañada por "el abuelo" en todo momento, hacen su vida diaria.

Aunque quien se dirige al lector parece ser la niña, los protagonistas (si nos fijamos en las imágenes) son los abuelos (él que aparece siempre presente y se comunica a través de la abuela) los cuales crean un final abierto con diferentes interpretaciones.

\section{RECURSOS UTILIZADOS:}

\begin{tabular}{|c|c|}
\hline \multicolumn{2}{|r|}{ NIVEL DE REALISMO (texto e imagen) } \\
\hline$x$ & -TEXTO MÁS QUE IMAGEN \\
\hline & -IMAGEN MÁS QUE TEXTO \\
\hline & -EQUILIBRIO ENTRE AMBOS \\
\hline & $\begin{array}{l}\text { lentarios: El texto es el realista, ya que nos cuenta } \\
\text { historia que podría ser real. Sin embargo, las } \\
\text { aciones nos cuentan algo que no se puede ver (como } \\
\text { caso del abuelo enterrado y su forma de vida...), es } \\
\text { la imagen representa lo ficticio e ilusorio. }\end{array}$ \\
\hline
\end{tabular}

TIPO DE HISTORIA

$x \quad$-NO CONTRADICTORIA (aunque alternativa) -CONTRADICTORIA (Ironía, humor...)

Comentarios: Las imágenes crean una historia alternativa donde dan vida a una persona que está muerta y la hacen partícipe de la historia.

\section{FINAL}

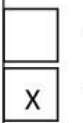

\section{-CERRADO (única posibilidad)}

-ABIERTO (diferentes posibilidades)

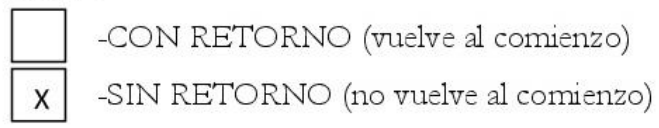

Comentarios: El final es sin retorno, es decir, no vuelve al comienzo y a su vez es abierto ya que nos da diferentes posibilidades. Mientras que el texto acaba sin más en la penúltima ilustración, el álbum finaliza con una ilustración (sin texto) donde no hay final claro ni concreto, por lo que nos insinúa distintas interpretaciones. Es decir, las imágenes son las que tienen la importancia para entender la historia y concretamente el final. 
Vemos a ambos, tanto al abuelo como a la abuela, los cuales aparecen en un barco, sin embargo no hay palabra que especifique a que se refiere, pudiendo dar varios puntos de vista. ¿La abuela muere y ambos se ven dentro de su historia del barco?, ¿dicha historia sucedió y cada vez que la abuela la cuenta, recuerda al abuelo?, etc.

COMENTARIOS Y OBSERVACIONES: Teniendo en cuenta todo lo anterior, podemos decir que en este álbum, las palabras tienen un nivel de realismo por encima de las imágenes ya que lo que nos dicen se acerca bastante a la realidad.

Sin embargo las ilustraciones juegan un papel importante ya que nos ayudan a aclarar $~$ interpretar cosas que con el texto se quedarían sin sentido, es decir, nos dan varias posibilidades. Las imágenes empleadas están cargadas de acciones y complementos y aunque no contradicen a las palabras, pero si nos dan una historia alternativa, es decir, la historia que nos cuentan las imágenes nos aporta una información extra que no nos da el texto, generando asi diferentes posibilidades de interpretación de la historia. Ésta nos está hablando de que han enterrado al abuelo, el cual acompaña a la familia en todo momento y aunque se supone que ha muerto, lo estamos viendo en forma de esqueleto pero con cierta personificación, actuando como si tuviera vida, lo cual se puede interpretar como su alma.

Las imágenes además, sugieren varios finales, donde el lector podrá interpretar unas cosas u otras, es decir, el final es abierto como anteriormente comenté. 


\section{La familia $C$}

\section{DATOS TEÓRICOS}

De Pep Bruno y Mariona Cabassa (2010). Ed. Kalandraka, Vigo. (Biblioteca Ugr de Bellas Artes)

7.056

BRU

fam

-RESUMEN: La familia C, es una familia a la que le encanta el circo y hacen que su vida diaria sea emocionante y llena de aventuras, incluso los días más grises.

\section{RELACIÓN TEXTO/ IMAGEN}

\begin{tabular}{|l|l|}
$\begin{array}{l}\text { LO QUE CUENTA EL } \\
\text { TEXTO }\end{array}$ & $\begin{array}{l}\text { Un niño va contando su día a día y el de su familia desde que se levantan, van al trabajo y } \\
\text { escuela, meriendan y van a ver su espectáculo favorito. El texto es bastante sencillo y } \\
\text { acompaña perfectamente a las imágenes donde todo lo que aparece en el texto, se ve reflejado } \\
\text { de manera metafórica en la imagen. }\end{array}$ \\
\hline $\begin{array}{l}\text { LO QUE CUENTA LA } \\
\text { IMAGEN }\end{array}$ & $\begin{array}{l}\text { Vemos a una familia que alterna la vida real y cotidiana con la fantástica y circense. Como si } \\
\text { todas las acciones diarias las relacionaran con el circo, hasta que casi al final se ve a la familia } \\
\text { en un coche (un día gris, sin color que se sale de lo anteriormente visto) dirigiéndose a ver un } \\
\text { espectáculo de circo. Las ilustraciones son extremadamente ricas y nos aportan una gran } \\
\text { información que se complementa de forma figurada con lo que dice el texto. }\end{array}$ \\
\hline LO QUE NOS DICE LA HISTORIA EN CUANTO A TEXTO E IMAGEN EN SU CONJUNTO: \\
$\begin{array}{l}\text { La historia nos cuenta la vida de una familia que le encanta el ambiente de circo y con imaginación e ilusión hacen que su } \\
\text { vida diaria sea mucho más alegre, colorida, divertida y llena de aventuras. Mientras que las palabras hablan de hacer el } \\
\text { desayuno, preparar la cartera, el trabajo de los padres, etc... los dibujos nos enseñan una familia haciendo malabares, saliendo } \\
\text { disparados de un cañón, haciendo magia, etc.... }\end{array}$
\end{tabular}
disparados de un cañón, haciendo magia, etc..

\section{RECURSOS UTILIZADOS:}

\section{NIVEL DE REALISMO (texto e imagen) \\ $X \quad$-TEXTO MÁS QUE IMAGEN \\ -IMAGEN MÁS QUE TEXTO \\ -EQUILIBRIO ENTRE AMBOS}

Comentarios: E1 texto es sin duda la parte realista del álbum, nos cuenta de forma sencilla lo que una familia hace cada día.

Las ilustraciones son maravillosas, llenas de color que nos envuelven en una historia absolutamente fantástica y hacen grande esta historia.

\section{FINAL}

$x$-CERRADO (única posibilidad) -ABIERTO (diferentes posibilidades)

\section{TIPO DE HISTORIA}

$x$-NO CONTRADICTORIA (aunque alternativa) -CONTRADICTORIA (Ironía, humor...)

Comentarios: Texto e ilustración van completamente abrazados donde se complementan a la perfección, difícil de entender uno sin lo otro.

La historia que nos muestran las ilustraciones es una historia alternativa a lo que nos dice el texto.

Comentarios: El final es sin retorno, es decir, sigue el curso de la historia, acaba hablándonos de lo que hacen después de todo el día.

Es un final cerrado ya que nos da una única posibilidad. El texto acaba en la penúltima ilustración, pero la imagen final nos aclara dicho texto y le da sentido al resto de la historia. 
Al leer el libro, puede que haya confusiones a la hora de actuar cada miembro, pero cuando al final se especifica que la familia se dirige a su espectáculo favorito, el cual es un circo, este nos puede ayudar a comprender mejor la historia.

COMENTARIOS Y OBSERVACIONES: En este álbum, las palabras tienen un nivel de realismo por encima de las imágenes, por lo que de forma sencilla nos cuentan algo que junto a las imágenes crean una gran historia.

Las ilustraciones juegan un papel importante, están llenas de color, de acciones fuera de lo común pero que can de la mano de lo que las palabras nos cuentan. Las imágenes empleadas están cargadas de acciones y complementos y aunque no contradicen a las palabras, si nos dan una historia alternativa, donde se mezcla realidad y ficción.

Las imágenes nos dan un único final cerrado, que nos aclara el sentido de la historia.

El texto nos habla de la familia al completo, por lo que podemos pensar que el hecho de que les guste tanto el circo, hacen que vivan su vida más intensamente, imaginándose como personajes de circo (malabaristas, trapecistas, magos, domadores, equilibristas, etc...), ya que en la escena final cuando ellos aparece como público, los personajes que aparecen actuando son equilibristas, malabaristas, magos, etc., relacionándose asi con todo lo anterior. 


\section{3.jNo!}

\section{DATOS TEÓRICOS}

De Marta Altés (2017). Ed. Thule, Barcelona. (Biblioteca Ugr de Bellas Artes)

-1ºubliCACIÓN: No! (2010). Ed. Child's Play (International) Ltd, Britain.

-RESUMEN: Esta historia es sobre un perro simpático, cuyas intenciones son buenas. Él piensa que se llama No, pero realmente es lo que la gente grita cuando hace ciertas cosas que él cree que están bien.

\section{RELACIÓN TEXTO/ IMAGEN}

\begin{tabular}{|c|c|}
\hline $\begin{array}{l}\text { LO QUE CUENTA EL } \\
\text { TEXTO }\end{array}$ & $\begin{array}{l}\text { El protagonista es un perro que habla en primera persona y empieza diciendo que su nombre } \\
\text { es No. Se porta muy bien y su familia siempre tiene su nombre en la boca diciéndole jno!. } \\
\text { Pero él les ayuda a ir más rápido; a probar la comida por si está mala; a buscar tesoros; } \\
\text { ordenarles los periódicos; ayudarles con la colada... y parece que lo quieren muchísimo. } \\
\text { Sin embargo, hay algo que no entiende, dpor qué le compraron un collar con el nombre de } \\
\text { Rufus?. } \\
\text { El texto es bastante sencillo. Mientras que en una página se dice lo que el perro hace, en la } \\
\text { otra página (pero misma ilustración doble) aparece siempre un jnooo!. }\end{array}$ \\
\hline $\begin{array}{l}\text { LO QUE CUENTA LA } \\
\text { IMAGEN }\end{array}$ & $\begin{array}{l}\text { Se puede ver a un perro que se dirige al espectador, contento, alegre y bueno. } \\
\text { Después se observa cómo va corriendo atado con una correa; cogiendo comida de encima de } \\
\text { la mesa; escarbando en el jardín; rebozándose en el barro; descansando encima de la cama } \\
\text { después de haber desordenado y ensuciado el dormitorio; destrozando los periódicos; sacando } \\
\text { la comida de la basura; cogiendo la ropa tendida y varias cosas más que hace con unos niños. } \\
\text { Tras esto el perro esta triste y dubitativo mientras mira su collar, donde finalmente se ve que } \\
\text { tiene escrito el nombre de Rufus. } \\
\text { Las ilustraciones están llenas de detalles y nos aportan una gran in formación contradictoria a } \\
\text { lo que nos dice el texto. }\end{array}$ \\
\hline
\end{tabular}

\section{LO QUE NOS DICE LA HISTORIA EN CUANTO A TEXTO E IMAGEN EN SU CONJUNTO:}

La historia nos presenta al protagonista en primera persona, un perro que dice llamarse No y portarse muy bien. Según él, su familia siempre lo está mencionando.

En las ilustraciones se ven varias acciones que realiza el perro, pero a la vez estas ilustraciones están acompañadas siempre de la palabra jno!

Mientras las personas le regañan diciéndole que no lo haga, él cree que lo está haciendo todo bien, y que realmente el "no" es porque él se llama así, por eso al final está muy dubitativo y no entiende porque pone Rufus en su collar, el cual es su verdadero nombre.

\section{RECURSOS UTILIZADOS:}

\section{NIVEL DE REALISMO (texto e imagen) -TEXTO MÁS QUE IMAGEN -IMAGEN MÁS QUE TEXTO $x \quad$-EQUILIBRIO ENTRE AMBOS}

Comentarios: Ambos elementos son realistas, ya que nos cuenta una historia que podría ser real.

El texto es más sencillo por lo que las imágenes nos ayudan a entender la realidad de la historia dándonos una visión más amplia de lo que realmente sucede.

\section{TIPO DE HISTORIA}

-NO CONTRADICTORIA (aunque alternativa)

x -CONTRADICTORIA (Ironía, humor...)

Comentarios: Las imágenes nos cuentan una historia diferente a la del texto, en forma irónica y con un toque de humor, las ilustraciones nos hacen comprender realmente la historia ya que el texto nos muestra el punto de vista del perro que es muy diferente a lo que sucede de verdad. 


\section{FINAL}

$x$-CERRADO (única posibilidad)

$X$-CON RETORNO (vuelve al comienzo)

-ABIERTO (diferentes posibilidades) $\quad \square$-SIN RETORNO (no vuelve al comienzo)

Comentarios: El final nos da una única posibilidad, donde nos aclara toda la historia, al mostrarnos el nombre real del perro. No vuelve al comienzo por lo que es un final sin retorno.

Podemos ver lo que tanto le inquieta, el por qué aparece el nombre de Rufus en su collar, cuando se supone que se llama No.

A lo largo de la historia el piensa que hace las cosas bien, puesto que la gente le dice No y según el perro, ese es su nombre. Sin embargo es al final donde se aclara cual es el nombre verdadero.

COMENTARIOS Y OBSERVACIONES: En este libro, las entre imgenes y texto existe un equilibrio en cuanto a realismo. Ambos nos cuentan una historia que podría darse en la vida real. Al fin y al cabo es la historia de un perro y su día a día, aunque desde el punto de vista del perro.

Las ilustraciones, son muy ricas y nos ayudan a entender la realidad de la situación y ver que lo que el perro cree, no es lo que ciertamente es. Las imágenes empleadas están cargadas de acciones y complementos que contradicen a las palabras pero con toques de humor y desde la inocencia del protagonista.

La historia tiene final cerrado y con retorno, que nos aclara en cierto modo la actitud y comportamiento del perro (el piensa que todo lo que hace está bien y la gente lo quiere mucho porque siempre lo están llamando).

El libro nos habla sobre como los humanos vemos ciertas acciones que hacen los animales y no nos parecen correctas mientras que ellos (concretamente Rufus), pueden entender mal, o simplemente hacerlas con buena intención, pero sin ser las adecuadas. A la vez nos habla también del cariño, respeto y adoración del perro por sus dueños y como siempre intenta ayrudarlos (según su punto de vista). 


\section{La historia de una manzana roja}

De Jan Lööf (1987). Ed. Miñón, Valladolid. (Internet archive: https://archive.org/details/historiadeunaman001)

-1ºUBLICACIÓN: Sagan om det röda äpplet. (1974). Ed. Carlsen, Copenhague.

-RESUMEN: La historia es sobre un hombre con traje de rayas que decide comprar una manzana, pero el frutero intenta engañarlo y le vende una de plástico, sin embargo este cuida y oculta una apetitosa manzana roja para ganar un premio.

Suceden una serie de hechos que harán que desencadenan un final inesperado.

\section{RELACIÓN TEXTO/ IMAGEN}

LO QUE CUENTA EL $\quad$ Un día un hombre con traje a rayas pasa por una frutería para comprar una manzana, pero el TEXTO $\quad$ frutero decide engañarlo y le da una de plástico, diciéndole que tiene que ponerla al sol para que madure. Sin embargo, él tiene en su jardín una espléndida manzana roja para ganar un premio.

Una vez en casa, el hombre del traje deja la manzana en la ventana para que madure y se pone con la maqueta de un barco, sin darse cuenta de que su papagayo hace que la manzana caiga por la ventana golpeando a una anciana, la cual regaña a un niño que pasa por allí y que sale corriendo y llorando. Esto hace que el coche del director que pasaba por alli, se estrelle con la valla del frutero.

Mientras frutero, director y niño discuten, otro que va en bici, entra en el jardín y se lleva la manzana para dársela a la maestra; pero esta está enfadada porque los niños están entretenidos con la policía, la cual busca a un ladrón que está allí y que al ser descubierto huye llevándose la manzana; pero choca con el director y la manzana sale despedida, la cual es cogida por unos bomberos que van a rescatar a un gato. Dejan la manzana en una ventana justo cuando el hombre del traje se acuerda de su manzana, por lo que al ver que estaba roja decide darle las gracias al frutero, el cual no entiende por qué no está su manzana en su jardín.

El texto es sencillo y va de la mano de las ilustraciones.

LO QUE CUENTA LA

Un hombre va andando y entra en una frutería donde le dan una manzana verde, pero se ve IMAGEN

al frutero regando una manzana roja que cuelga de un árbol.
El hombre del traje va a su casa, coloca la manzana verde en la ventana y se pone a hacer cosas.

La manzana cae a la calle y le da a una anciana, esta regaña a un niño que caminaba por allí; el niño se va corriendo por mitad de la calle y un coche que pasaba choca contra las vallas del frutero, dejando paso al árbol con la manzana roja (mientras se ve a un policía que persigue a un hombre); a su vez, un niño que va en bici entra y coge la manzana para llevarla a la escuela, donde se puede ver a un hombre escondido.

La policía aparece en la escuela, y el hombre sale corriendo llevándose la manzana, pero se choca y la manzana sale despedida por la ventana, cayendo en las manos de unos bomberos que se dirigen a la casa del hombre de rayas para rescatar a un gato, dejando en la ventana la manzana roja. Finalmente, el hombre del traje al verla, camina de nuevo por la ciudad, se la enseña al frutero y se va.

Las imágenes, ricas en detalles, ocupan un $80 \%$ y complementan perfectamente al texto.

\section{LO QUE NOS DICE LA HISTORIA EN CUANTO A TEXTO E IMAGEN EN SU CONJUNTO:}

La historia trata sobre las casualidades, incidentes y confusiones que hacen que quien se iba a burlar de una persona como es el caso del frutero dando la manzana de plástico al hombre de traje), acabe siendo el burlado y quien iba a ser burlado, sin darse cuenta, acabe recompensado (con la manzana roja).

El toque de humor, junto con los hechos que van sucediendo capta la atención del lector.

Además, la historia hace que conozcamos lugares y personas que forman parte de una ciudad, que podamos recorrerla a través de las ilustraciones y formemos parte de ella. 


\section{RECURSOS UTILIZADOS:}

NIVEL DE REALISMO (texto e imagen)
\begin{tabular}{|l|l}
\hline & -TEXTO MÁS QUE IMAGEN \\
\hline \hline & -IMAGEN MÁS QUE TEXTO \\
\hline $\mathrm{X}$ & -EQUILIBRIO ENTRE AMBOS
\end{tabular}

Comentarios: Ambos elementos son realistas, ya que nos cuenta una historia que podría ser real.

Sin embargo las imágenes nos dan una visión más amplia del barrio y distintos personajes que aparecen en el texto.
TIPO DE HISTORIA

\section{$\square$-NO CONTRADICTORIA (aunque alternativa) -CONTRADICTORIA (Ironía, humor...) \\ $x$-COMPLEMENTO CON DETALLES DE CONTRAPUNTO}

Comentarios: Las imágenes no contradicen al texto, añaden información visual que a veces no aparece en el texto.

Realmente este álbum no es de contrapunto en su conjunto pero tiene juegos de contrapunto, por ejemplo, cuando aparece el ladrón en la imagen y no en el texto, sin embargo, no es hasta tres páginas después cuando las palabras hablan del ladrón.

Mientras que estamos atentos al choque del coche con la vaya (ya que es de lo que nos dice la historia), podemos dejar pasar que hay un hombre que es perseguido por la policía y que posteriormente aparece escondido dentro de la escuela.

\section{FINAL}

\begin{tabular}{|l|}
\hline $\mathrm{X}$ \\
\hline \hline \\
\hline
\end{tabular} -CERRADO (única posibilidad)
-ABIERTO (diferentes posibilidades)

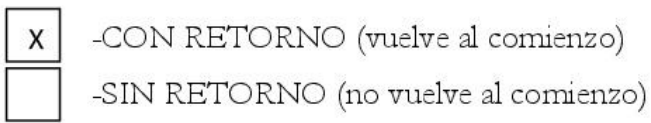

Comentarios: El final es con retorno, es decir, hace referencia al principio de la historia.

El álbum empieza hablando de un hombre de traje de rayas que quiere una manzana y va a una fiutería, y acaba con dicho hombre comiéndose una manzana y yendo a la frutería (para agradecerlo).

Suceden una serie de circunstancias que hacen que no esperes el final, ya que este vuelve a tomar relación con el principio. No obstante, es un final cerrado, ya que no da varias posibilidades: el protagonista acaba comiéndose la manzana que tanto ansiaba.

COMENTARIOS Y OBSERVACIONES: Teniendo en cuenta todo lo anterior, podemos decir que en este álbum, existe un equilibrio en cuanto a realismo entre imágenes y texto. Ambos nos cuentan una historia que podría suceder, aunque las ilustraciones nos aporten más información.

Palabras e imágenes van de la mano en el comienzo y final, pero aunque en un principio los dibujos parecen ser sencillos sin dar información de más, es en el desarrollo de la historia cuando van apareciendo detalles que crean curiosidad (como es el caso del ladrón) y que pasan por alto en el texto.

Las ilustraciones juegan un papel importante, cargadas de detalles, las cuales nos ayudan a ver más cosas que con el texto se quedarían cortas, aunque en ningún momento contradicen a las palabras. Como ya se ha comentado anteriormente, el momento en que vemos un choque entre un coche y una valla (y el texto nos habla solo de eso), también se puede apreciar la figura de un hombre sospechoso (que en la anterior imagen también aparece y parece llevar un arma apuntando a una mujer) que sale corriendo con dinero y que a su vez es perseguido por un policía. Tanto el hombre sospechoso como el policía serán mencionados después en la historia y tendrán una gran importancia en ella.

El final cerrado da una sola interpretación tanto en imagen como en texto, donde ambos elementos van unidos, haciendo reseña al principio del cuento.

Este libro donde hay partes de contrapunto aunque el álbum en sí sea de complemento, tiene un juego bastante interesante a mitad de la historia, cuando las ilustraciones nos presentan al ladrón pero no las imágenes, ya que lo hacen más tarde. Esto es atractivo porque si se lee pero no se presta atención a los detalles, no se ve al ladrón y no se sabrá de él hasta que lo mencione el texto, por lo que en ese caso necesitas volver atrás. Por el contrario, en el caso en que con las imágenes (sin la ayuda del texto) se descubra este personaje, hará que se mantenga la curiosidad e interés por seguir con la historia. 


\section{Rosie's Walk}

\section{DATOS TEÓRICOS}

De Pat Hutchins (2015). Ed. Little Simon, New York. (Biblioteca Ugr de Bellas Artes)

-1º PUBLICACIÓN: Rosie’s Walk .(1967). Ed. Macmillan, New York.

-RESUMEN: Rosie es una gallina que sale a caminar un día sin saber que es perseguida por un zorro travieso, sin embargo todos sus intentos por alcanzarla, acaban siendo fallidos. Finalmente Rosie acaba regresando tranquilamente a su casa a tiempo para la cena.

\section{RELACIÓN TEXTO/ IMAGEN}

LO QUE CUENTA EL $\quad$ La gallina Rosie sale a pasear a través del corral, alrededor del estanque, por encima del heno, TEXTO $\quad$ por el molino, vallas e incluso bajo las colmenas y así regresar al gallinero a tiempo para cenar. El texto es breve y sencillo y suele aparecer cada dos páginas dobles.

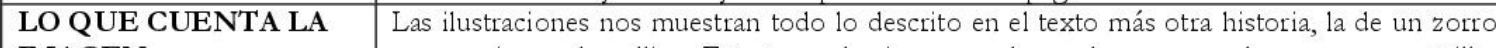

IMAGEN $\quad$ que persigue a la gallina. Este zorro la sigue por el corral, pero se golpea con un rastrillo; alrededor del estanque, pero cae y se empapa de agua; por encima del heno, pero se cuela entre él; por el molino, pero le cae un saco de harina; a través de una valla, pero cae encima de una carreta que a su vez choca con una colmena de abejas las cuales salen volando detrás del zorro, por lo que el zorro sale corriendo y finalmente se aleja de la gallina.

\section{LO QUE NOS DICE LA HISTORIA EN CUANTO A TEXTO E IMAGEN EN SU CONJUNTO:}

La historia narrada nos cuenta la caminata de una gallina desde que sale del corral hasta que regresa para la cena. Mientras tanto, sin darse cuenta, es perseguida por un zorro al cual no paran de pasarle cosas que hacen que no pueda alcanzar al otro animal.

Las ilustraciones a doble página van de dos en dos, es decir, mientras que las primeras se centran en lo que dice el texto (aunque el zorro siempre está presente), en las segundas no aparece el texto y se centra en lo que le sucede al zorro.

\section{RECURSOS UTILIZADOS:}

NIVEL DE REALISMO (texto e imagen)
\begin{tabular}{|l|l}
\hline & -TEXTO MÁS QUE IMAGEN \\
\hline \hline & -IMAGEN MÁS QUE TEXTO \\
\hline $\mathrm{x}$ & -EQUILIBRIO ENTRE AMBOS
\end{tabular}

Comentarios: Ambos elementos son realistas, ya que nos cuenta una historia que podría ser real.

Sin embargo las imágenes nos dan una visión más amplia del sitio por el que Rosie se mueve, pudiendo asi ver los hechos que le suceden al zorro.

\section{TIPO DE HISTORIA \\ $\square$-NO CONTRADICTORIA (aunque alternativa) \\ x -CONTRADICTORIA (Ironía, humor...)}

Comentarios: Mientras que las palabras nos hablan de una gallina que pasea tranquila, confiada, y donde en ningún momento se menciona a un zorro; las imágenes nos cuentan otra historia diferente con un toque de ironía, la de una gallina que corre un gran peligro ya que un zorro la persigue.

\section{FINAL}

$x$-CERRADO (única posibilidad) -ABIERTO (diferentes posibilidades)

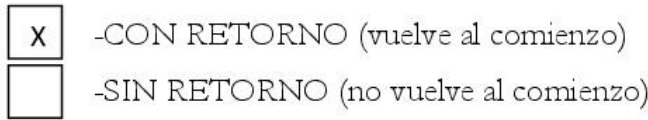

Comentarios El final es con retorno, es decir, hace referencia al principio de la historia.

El álbum comienza con la gallina saliendo de su gallinero y acaba con la gallina volviendo al gallinero. Además es un final cerrado, ya que da una única posibilidad donde Rosie vuelve al corral para la cena. 
COMENTARIOS Y OBSERVACIONES: Teniendo en cuenta todo lo anterior, podemos decir que en este álbum, existe un equilibrio en cuanto a realismo entre imágenes y texto. Ambos nos cuentan una historia que podría suceder, aunque las ilustraciones nos aporten más información (inclusive en la portadilla donde se muestra el recorrido total que hace la gallina y que es explicado paso a paso en la historia).

Palabras e imágenes cuentan una historia diferente, mientras que al realizar la lectura, no se hace referencia al zorro y parece que la historia es el simple paseo de una gallina; las ilustraciones nos muestran otra cosa, que la gallina realmente está amenazada por un zorro, sin que ella sea consciente, pero como al zorro no paran de pasarle cosas por lo que nunca logra alcanzar a Rosie. Las ilustraciones juegan un papel importante, están llenas de detalles, las cuales nos ayudan a ver más cosas de lo que dicen las palabas, creando una historia contradictoria llena de ironía y humor.

El álbum con las ilustraciones nos cuentan dos historias, la de la gallina (que es la historia a la que el texto se refiere) y la del zorro, es decir, si tan solo se pudiera leer el libro con las imágenes, se podrían contar historias alternativas, a la que dice el texto.

El final es cerrado ya que no da posibles interpretaciones y, a su vez, se refiere al principio de la historia, por lo que además es un final con retorno. 


\section{Granpa}

De John Burningham (2003). Ed. Red fox, London. (Biblioteca Ugr de Bellas Artes)

-1ºublCACIÓN: Granpa. (1984). Ed. Jonathan Cape, Britain.

-RESUMEN: Una niña y su abuelo comparten un montón de momentos juntos, plantan semillas, cantan, juegan a las muñecas, etc. Por lo que se genera una gran amistad entre ellos.

\section{RELACIÓN TEXTO/ IMAGEN}

LO QUE CUENTA EL $\quad$ El único texto es un diálogo entre abuelo y nieta donde ella le hace preguntas propias de TEXTO un niño acerca del mundo y él le cuenta según sus recuerdos de cuando era niño. Este dialogo puede ser confuso puesto que no tiene mucho sentido lo que dice uno y el otro. Mientras que el texto que hace referencia al abuelo está escrito en letra normal, cuando habla o cuestiona la niña, el texto está escrito en cursiva, para que de este modo sea sencillo identificar quien habla.

Si no se viera ninguna imagen, sería muy complicado entender la historia, puesto que las palabras empleadas podrían no tener mucha coherencia, ni contar una historia concreta. Por ejemplo en "No habría lugar para que crezcan todas las pequeñas semillas", dice el abuelo, "¿los gusanos van al cielo?", pregunta la niña. Este fragmento no nos aporta casi nada de información, por lo que no sabemos a qué se refieren.

LO QUE CUENTA LA Las ilustraciones dobles se suelen dividir en dos partes, la primera con imágenes IMAGEN monocromáticas y la segunda con imágenes a color llenas de color aunque no muy bien definidas.

En las ilustraciones a color vemos un abuelo y su nieta realizando una serie de actividades, en in invernadero plantando; disfrazándose y cantando; jugando con las muñecas; en el jardín "alimentando" a los muñecos y tomando lo que parece ser helado; yendo a la playa; jugando a la comba y montando en bici; pescando, o andando por la nieve. Después se ve al abuelo en tono amarillento sentado en el sofá con medicamentos a su lado, por lo que se entiende que esta enfermo. De nuevo él se ve en el sofá pero con su nieta encima, para acabar con las últimas ilustraciones donde aparece el so fá sin nadie.

Por otra parte las imágenes de un solo color nos muestran una serie de herramientas para plantar; unos niños cantando junto a un hombre que toca el piano; un animal vestido de mujer (el mismo que aparece como un muñeco que tiene la niña); una mesa con té y pasteles; una playa con arena, palas y cubos; unos cuantos accesorios de deporte, pelotas y un baúl; pescando una ballena; niños tirándose con trineos; medicamentos, bolsa de agua y termómetro; un barco en mitad del mar; y finalmente la niña sola encima de una silla con aspecto triste.

\section{LO QUE NOS DICE LA HISTORIA EN CUANTO A TEXTO E IMAGEN EN SU CONJUNTO:}

La historia nos habla de la muerte y de una amistad enorme que hay entre una niña y su abuelo.

Podemos observar 4 elementos fundamentales que aparecen en el libro: El texto normal o cursivo según quien hable, las imágenes con un color que nos muestran los recuerdos del abuelo, lo que piensa o imagina, y las imágenes a color para mostrar lo que está pasando realmente.

Ambos realizan acciones cotidianas o divertidas que los unen mucho, desde ir a la playa hasta jugar a la comba, por ello podemos notar la intensidad de la relación que existen entre ambos, sin embargo la niña hace preguntas (a veces sin sentido) por lo que el abuelo cuenta según sus recuerdos. Otras veces simplemente el dialogo sin más, referente a lo que están haciendo.

Pero todo esto cambia cuando se ve al abuelo solo, sentado en el sofá, y rodeado de medicamentos. Después ya no estarán haciendo cosas al aire libre, si no los dos viendo la tele, para finalmente acabar con el sillón vacío y la niña triste (aunque en un solo color) mirando la ausencia del abuelo.

En la última ilustración se ve a la niña con su carro de muñecas corriendo sola. 


\section{RECURSOS UTILIZADOS:}

\section{NIVEL DE REALISMO (texto e imagen) \\ -TEXTO MÁS QUE IMAGEN \\ X IMAGEN MÁS QUE TEX'TO \\ -EQUILIBRIO ENTRE AMBOS}

Comentarios: En este caso las imágenes nos ayudan a entender el texto tan confuso.

Nos aportan mucha más información que el texto y aunque algunas imágenes sean un poco exageradas (como el abuelo saltando la comba), sirve para darle más intensidad a la historia y asi comprender el grado de afinidad y el tipo de relación entre la nieta y el abuelo.
TIPO DE HISTORIA

$x$-NO CONTRADICTORIA (aunque alternativa) -CONTRADICTORIA (Ironía, humor...)

Comentarios: Hay una mezcla de presente con pasado, por lo que se cuentan historias alternativas dentro de la complejidad del dialogo aparentemente sin sentido.

El texto no nos cuenta una historia concreta, habla de diferentes historias, por lo que esta ambigüedad hace que haya un margen entre texto e imagen para que el lector pueda imaginar.

\section{FINAL}

-CERRADO (única posibilidad)

$x$-ABIERTO (diferentes posibilidades)

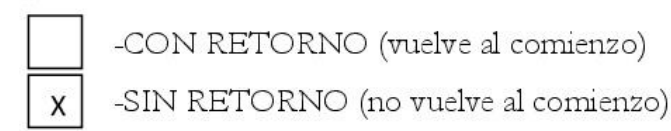

Comentarios: Este libro tiene un final abierto ya que sugiere diferentes posibilidades. Acaba con la ausencia del abuelo en las ultimas ilustraciones lo cual se puede interpretar como que ha muerto, sin embargo en ningún momento el texto hace referencia a ello, por lo que a la vez es un final sin retorno puesto que no vuelve al inicio de la historia.

COMENT ARIOS Y OBSERVACIONES: Este libro trata temas más serios pero de una forma muy sencilla. Es un buen libro para tratar con los niños el fondo de la muerte y el de la amistad y amor por tu familia.

Imágenes y texto que sirven para identificar ciertas cosas, es decir, diferentes tipos de palabras según quien habla, y diferentes colores en las imágenes para ver que es real y que imaginación o recuerdo.

En este caso la imagen se acerca más a la realidad y nos cuenta diferentes historias, sin embargo el texto con diálogos liosos, sin sentido o conversaciones que no llevan a nada hacen que sea la parte del libro más surrealista.

Además las ilustraciones están cargadas de detalles y nos ayudan a comprender más la historia, ya que si solo se contara con las palabras sería imposible de entender.

Las ilustraciones cuentan diversas historias, pasadas, imaginarias y presentes que nos dan alternativas a lo que dice el texto.

El final abierto cuenta con varias posibilidades (aunque lo más posible es la muerte del abuelo). 


\section{Lily takes a walk}

\section{DATOS TEÓRICOS}

De Satoshi Kitamura (1991). Ed. Dutton children's book, New York (Biblioteca Ugr de Bellas Artes)

-1º PUBLICACIÓN: Lily takes a walk (1987). Ed. Blackie and son Ltd, London.

-RESUMEN: Lily sale a pasear con su perro Nicky, pero lo que para ella es un paseo relajante del que disfruta, para su perro es un paseo lleno de peligros.

\section{RELACIÓN TEXTO/ IMAGEN}

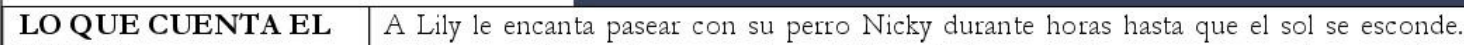
\begin{tabular}{l|l} 
TEXTO & Incluso cuando empieza a anochecer, Lily se siente protegida por su perro asi que no tiene
\end{tabular} miedo.

Hoy durante el paseo hizo la compra, se paró a ver las estrellas, incluso se paró en el puente para dar las buenas noches a los patos y gaviotas. Sin embargo el mejor momento es cuando está llegando a casa ve su luz encendida por la ventana y el olor de la cena cocinándose. La madre y padre de Lily siempre quieren ver que es lo que ha visto en su paseo.

Finalmente cuando llega la hora de ir a la cama, Lily le dice a su perro que hoy han tenido un buen paseo.

El texto simple nos explica la visión de la niña de forma natural.

LO QUE CUENTA LA Ena niña pasea con su perro, pero mientras que ella lo disfruta, el perro está asustado ya que ve elementos que cobran vida como un cubo de basura, un árbol, las farolas, hombres que salen de un cartel de un anuncio gigante, un monstruo parecido al del lago Ness, etc. Cuando llegan a la casa, durante la cena la niña habla con sus padres y el perro inquieto no para de pensar en todo lo que ha visto.

Finalmente niña y perro se van quedando dormidos.

Las ilustraciones llenas de detalles mezclan la realidad con la fantasía.

\section{LO QUE NOS DICE LA HISTORIA EN CUANTO A TEXTO E IMAGEN EN SU CONJUNTO:}

La historia nos cuenta un paseo de una niña con su perro. Sin embargo este paseo que en un principio puede parecer algo cotidiano, como ir a comprar, ver las estrellas, pasear por las calles o saludar a los patos del rio, etc se convierte en una pesadilla a ojos del perro que ve monstruos y cosas que cobran vida, los cuales expresan sus sentimientos y temores más grandes, por lo cual se siente intimidado y asustado (aunque el perro en ningún momento está humanizado por lo que no puede verbalizar sus miedos).

\section{RECURSOS UTILIZADOS:}

\section{NIVEL DE REALISMO (texto e imagen)}

$X$-TEXTO MÁS QUE IMAGEN

$$
\text { -IMAGEN MÁS QUE TEXTO }
$$

-EQUILIBRIO ENTRE AMBOS

Comentarios: Aunque las imágenes nos aportan mucha información extra a lo que dice el texto, son las palabras las que se acercan más a la realidad.

\section{TIPO DE HISTORIA}

$\square$-NO CONTRADICTORIA (aunque alternativa) $x$-CONTRADICTORIA (Ironía, humor...)

Comentarios: Las palabras nos hablan de la tranquilidad de Lily al pasear, confiada y "protegida" por su perro, mientras las imágenes nos muestran al perro asustado y desconfiado ya que ve un montón de monstruos y cosas surrealistas que su dueña no ve. 


\section{FINAL}

X CERRADO (única posibilidad)

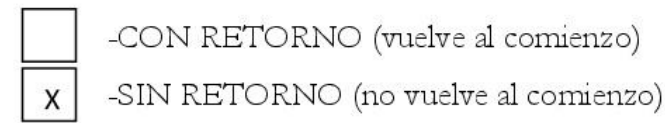

Comentarios: La historia tiene un único final, el final del día tras el paseo y la cena cuando tanto Lily como su perro descansan.

La historia empieza con el paseo y acaba con los protagonistas a punto de dormirse, por lo que no es un final con retorno.

COMENTARIOS Y OBSERVACIONES: Este es un álbum que nos habla de dos puntos de vista, el punto de vista de una niña la cual se siente segura porque su perro la acompaña, y el punto de vista del perro, miedoso e inseguro. Cada uno tiene su forma de ver lo que sería un "simple" paseo. Nos muestra con ilustraciones aquello que no se puede contar con palabras, por lo que los niños se pueden sentir identificados con los miedos del perro o con la inalterable Lily la cual no ve problema alguno.

El texto real, va acompañado de imágenes que lo ilustran, pero que a su vez nos cuenta una historia contradictoria, llena de ficción.

El final cerrado nos da una única posibilidad, y no hace referencia al comienzo asi que es sin retorno.

El libro nos habla sobre el cariño que tenemos a nuestras mascotas y como nos sentimos protegidos cuando las tenemos cerca. 


\section{Odio a mi osito de peluche}

\section{DATOS TEÓRICOS}

De David McKee (2005). Anaya, Madrid. (Biblioteca Ugr de Bellas Artes)

-1ºublCACIÓN: I Hate My Teddy Bear. (1982). Ed. Andersen Press Ltd, Britain.

-RESUMEN: Juan y Brenda son dos niños que no paran de discutir sobre sus osos de peluche, mientras tanto van sucediendo una serie de cosas extrañas a su entorno a ellos.

\section{RELACIÓN TEXTO/ IMAGEN}

\begin{tabular}{|l|l|}
\hline $\begin{array}{l}\text { LO QUE CUENTA EL } \\
\text { TEXTO }\end{array}$ & $\begin{array}{l}\text { La madre de Brenda va a visitar a la madre de Juan y Brenda va a jugar con Juan, pero le } \\
\text { dicen que vayan fuera a jugar con sus ositos de peluche. } \\
\text { Una vez fuera, ambos empiezan a decir que odian a sus ositos pero Juan dice que el suyo es } \\
\text { mejor, asi que de nuevo empiezan a discutir por cual es mejor. Cuando la madre de Juan los } \\
\text { llama para merendar, ambos ositos empiezan a hablar entre ellos. } \\
\text { El texto es básicamente un diálogo entre los protagonistas, algo sencillo que no da gran } \\
\text { información y que aparece en cada una de las páginas }\end{array}$ \\
\hline $\begin{array}{l}\text { LO QUE CUENTA LA } \\
\text { IMAGEN }\end{array}$ & $\begin{array}{l}\text { Las imágenes son complejas, llenas de detalles y nos dan una gran cantidad de información. } \\
\text { Por una parte, hacen referencia a lo que dice el texto donde se ve a los protagonistas. } \\
\text { Por otra, se ven una serie de personajes, acciones y escenarios ajenos a lo que dicen las } \\
\text { palabras, que nos muestran diferentes historias, historias posibles, paralelas y misteriosas } \\
\text { como, por ejemplo la de un guante que se ha perdido; personas y objetos que insinúan } \\
\text { hechos y emociones; o los preparativos para una exhibición con figuras que van de un lado } \\
\text { para otro (los cuales siguen el curso de la historia contada en todo momento, donde se ven } \\
\text { grupos de hombres misteriosos que aparecen transportando enormes manos y pies por allá } \\
\text { por donde pasan los niños). }\end{array}$ \\
\hline \hline
\end{tabular}

\section{LO QUE NOS DICE LA HISTORIA EN CUANTO A TEXTO E IMAGEN EN SU CONJUNTO:}

Las imágenes nos cuenta diferentes historias que suceden tanto dentro de la casa, como en el espacio público. Historias que en un principio pueden ser cotidianas como dos niños que discuten por su osito (lo cual aparece también en el texto), llantos, gente que espía, cuchichea, miradas y un sinfín de cosas... hasta hombres misteriosos que transportan figuras grandes de las cuales no sabemos nada hasta que son desveladas al final.

\section{RECURSOS UTILIZADOS:}

\section{NIVEL DE REALISMO (texto e imagen) \\ $X$-TEXTO MÁS QUE IMAGEN -IMAGEN MÁS QUE TEXTO -EQUILIBRIO ENTRE AMBOS}

Comentarios: Aunque las imágenes tienen más detalles y nos aportan mucha más información que el texto, es este el que con una conversación sencilla, se acerca más a la realidad.

Las imágenes tienen ciertos elementos de surrealismo, ciertas acciones o ciertos personajes fuera de lo normal, como, por ejemplo, los hombres que transportan sin más las figuras anteriormente comentadas, sin aparente relación con lo que dice el texto.

\section{TIPO DE HISTORIA}

$x$-NO CONTRADICTORIA (aunque alternativa) $\square$-CONTRADICTORIA (Ironía, humor...)

Comentarios: Las imágenes no contradicen al texto, añaden in formación visual por encima de lo que las palabras dicen. Las imágenes nos muestran diferentes historias que suceden de forma simultánea a la vez que los supuestos protagonistas (los niños y sus ositos) hacen referencia a lo que el texto cuenta. 


\section{FINAL}

\begin{tabular}{|c|c|c|}
\hline -CERRADO (única posibilidad) & $x$ & -CON RETORNO (vuelve al comienzo) \\
\hline -ABIERTO (diferentes posibilidades) & & -SIN RETORNO (no vuelve al comienzo) \\
\hline
\end{tabular}

Comentarios: Es un libro con posibles finales o desenlaces, al igual de posibles y diversas historias que admiten tantas lecturas como lectores. A su vez, si nos centramos en la historia que es contada, podemos decir que es un final con retorno, es decir, vuelve al principio (e incluso cerrado), donde de nuevo los nir̃os se reúnen con sus madres y meriendan. Sin embargo como este libro trata diferentes historias, también se puede ver que la última ilustración da sentido a la historia, donde al fin reconocemos en una exposición las figuras que eran transportadas.

COMENTARIOS Y OBSERVACIONES: Este es un libro infantil muy complejo incluso para los adultos asi que es muy probable que los niños al leer pasen cosas por alto.

Texto simple y real que acompaña bien a las ilustraciones pero que dice mucho menos de lo que ellas nos muestran. Además se presenta tanto en español como en inglés lo cual hace que sea un libro muy completo.

Imágenes llenas de elementos, objetos, personajes y acciones que hacen que si te paras a prestar atención, a la vez que ves historias relacionadas, llegue un punto donde pierdas un poco el sentido.

Algunas imágenes aparecen volteadas y sirven para contar diferentes historias dentro de una misma ilustración, por lo que es un recurso muy interesante para expresar tanto en tan poco.

Las ilustraciones cuentan diversas historias, paralelas y posibles que nos dan alternativas a un texto tan sencillo.

El final abierto con cantidad de posibilidades a las diferentes historias aunque cierra dos, por una parte la historia de los niños que es la que se narra, y por otra el misterio de las manos y pies que iban de un lado a otro.

Libro muy interesante que hará que los niños desarrollen su imaginación, se paren a observar las imágenes detenidamente y jueguen a desvelar el final. 


\section{Soy un artista}

\section{DATOS TEÓRICOS}

De Marta Altés (2017). Ed. Blackie Books S.L.U., Barcelona. (Biblioteca Ugr de Bellas Artes)

-1 PUBLICACIÓN: I am an artist (2013). Ed. MacMillan Children's Books, Britain.

-RESUMEN: La historia nos habla de un niño que se considera artista y no puede dejar de crear cosas porque todo le motiva. Sin embargo parece que su madre no lo entiende.

\section{RELACIÓN TEXTO/ IMAGEN}

LO QUE CUENTA EL $\quad$ El protagonista es un niño que habla en primera persona y nos dice que es un artista al igual TEXTO

LO QUE CUENTA LA que su madre aunque ambos lo ven de manera distinta. Mientras él ve arte por todas partes, ella parece que no, por lo que cree que su madre no lo entiende. El niño no puede dejar de crear cosas porque todo le inspira y nos habla sobre sus creaciones de la semana asi como de lo que le gusta la naturaleza, texturas, colores, e incluso formas, pero a pesar de ello está preocupado por su madre ya que no sabe qué le pasa, pero cree que es porque últimamente no le ha prestado la atención necesaria, por lo que decide crear algo especial para ella mientras duerme, lo cual titula "Oda a una madre".

El texto es bastante natural por lo que nos muestra la forma de pensar de un niño.

IMAGEN

Vemos a un niño con un bigote pintado y un montón de pinturas y maquillaje en el suelo, asi como un gato maquillado rodeado de utensilios colocados sin sentido.

También vemos a una mujer (su madre) medio dormida con un café en mano y al lado la misma mujer arreglada y maquillada.

Posteriormente ambos personajes aparecen juntos en algunas ilustraciones, cuando estas nos muestran al niño pintando en la pared y la madre inquieta regañándole, o el niño que ha hecho un agujero en la pared y la madre de nuevo que no parece conforme.

Asimismo vemos diferentes acciones que realiza el chico con pintura azul, fragmentando el espejo del baño; observando un frigorífico lleno de macetas, mientras los alimentos que había dentro aparecen tirados por el suelo; tumbado en el jardín desnudo cubierto de plantas a la vez que el suelo está lleno de pisadas; mirando una "escultura" hecha a base de perchas, ropa y utensilios de cocina; bañándose con una aglomeración de ropa y papeles; e incluso amontonando objetos creando como una especie de trono. La madre mientras ve preocupada como el montículo se desmorona, sin embargo intenta relajarse.

$\mathrm{El}$ infante tiene una idea y empieza a dibujar, la madre mientras se relaja en el so fá. Finalmente se observa la casa entera con sus habitaciones todas pintadas y aparentemente destrozadas y como el niño tranquilo y feliz, espera que su madre se despierte.

Las ilustraciones están son ricas en detalles aunque generalmente usa un fondo blanco que hace que resalten más.

\section{LO QUE NOS DICE LA HISTORIA EN CUANTO A TEXTO E IMAGEN EN SU CONJUNTO:}

La historia nos presenta al protagonista en primera persona, un niño que dice ser un artista al igual que su madre, la cual vemos antes y después de maquillarse y arreglarse. Sin embargo según el chico, ambos ven las cosas de manera distinta.

Mientras que la madre parece preocupada e inquieta, él ve arte en todas partes puesto que todo le inspira, por eso siempre está pintando a su gato e incluso paredes; experimentando con objetos (rompiendo cosas o haciendo "esculturas"), colores (pintando objetos), texturas (papeles y tejidos mojados en la bañera) o formas (amontonando todo tipo de elementos). Sin embargo se da cuenta de que a su madre le sucede algo asi que decide crear algo personal para ella.

La madre descansa asi que el niño aprovecha, pero según él su creación consiste en "pinturas" en paredes, ventanas, suelos, puertas, lámparas, lavabos o escaleras, "esculturas" con macetas, ropa, libros y un sinfín de caos que el chico ve como arte y al cual titula como "Oda a una madre". A la vez que lo vemos orgulloso, también vemos a su gato asustado con el pelo erizado lo cual suponemos que la madre ha despertado y ha visto esa "maravillosa" creación. 


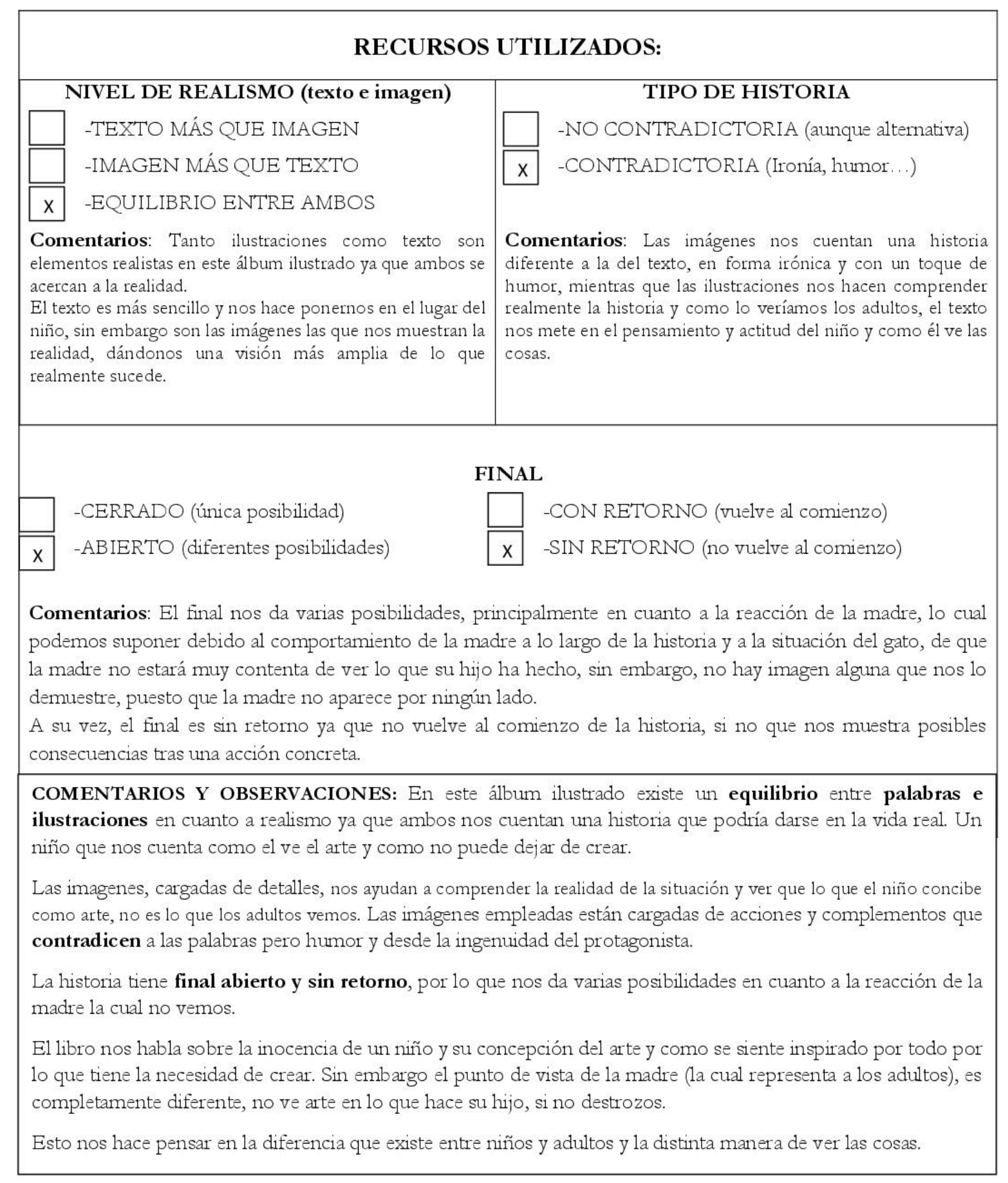




\section{E1 gato de Matilda}

\section{DATOS TEÓRICOS}

De Emily Gravett (2014). Ed. Picarona (ediciones Obelisco, S.L.), Barcelona. (Biblioteca Ugr de Bellas Artes)

-1º PUBLICACIÓN: Matilda's Cat. (2012). Ed. Macmillan Children's Books, Britain.

-RESUMEN: Matilda es una niña con un gato naranja a la que le gusta disfrazarse de él y jugar a juegos, sin embargo parece ser que a su gato no le gustan tanto.

\section{RELACIÓN TEXTO/ IMAGEN}

\begin{tabular}{|l|l|}
\hline $\begin{array}{l}\text { LO QUE CUENTA EL } \\
\text { TEXTO }\end{array}$ & $\begin{array}{l}\text { La historia nos habla sobre que le gusta al gato de Matilda como jugar con ovillos de lana, } \\
\text { cajas e incluso montar a triciclo. Además de hacer merendolas, los sombreros originales, } \\
\text { luchar contra el enemigo, dibujar, subirse a los árboles o leer cuentos antes de dormir. Sin } \\
\text { embargo de repente todo cambia, ahora todas esas cosas no le gustan al gato de Matilda. Lo } \\
\text { que realmente le gusta... es Matilda. } \\
\text { E1 texto es sencillo con frases cortas y a lo largo de la historia aparecen frases o palabras } \\
\text { tachadas (que al ver las ilustraciones nos daremos cuenta de que hacen re ferencia a lo que al } \\
\text { gato no le gusta). }\end{array}$ \\
\hline $\begin{array}{l}\text { LO QUE CUENTA LA } \\
\text { IMAGEN }\end{array}$ & $\begin{array}{l}\text { Una niña disfrazada similar a su gato se lo pasa genial jugando con ovillos de lana, cajas, } \\
\text { montando en triciclo (se puede ver una cesta para gatos en él), preparando una merienda, } \\
\text { probándose sombreros, jugando con una espada, dibujando, subiéndose a los árboles y } \\
\text { leyendo cuentos (el cuento de "perros" que también pertenece a la misma autora de este libro), } \\
\text { sin embargo a su gato no parece gustarle mucho todo aquello que la niña hace, lo que sí parece } \\
\text { gustarle es dormir con ella. } \\
\text { Las ilustraciones son sencillas, pero divertidas. }\end{array}$ \\
\hline LO QUE NOS DICE LA HISTORIA EN CUANTO A TEXTO E IMAGEN EN SU CONJUNTO:
\end{tabular}

La historia nos habla sobre una niña a la que le encanta jugar a los típicos juegos que le gustan a los gatos, meterse en cajas, jugar con ovillos, subirse a los árboles, pasear en triciclo (aquí podemos ver una cesta para gatos donde ya comente anteriormente)... disfruta tanto haciendo eso que incluso se disfraza de gato. Pero parece ser que a su gato no le hace tanta gracia $\circ$ al menos eso demuestra con sus caras, parece aburrirse. Sin embargo lo que realmente le gusta es Matilda y pasar tiempo con ella.

\section{RECURSOS UTILIZADOS:}

\section{NIVEL DE REALISMO (texto e imagen)}

\section{-TEXTO MÁS QUE IMAGEN}

\section{-IMAGEN MÁS QUE TEXTO}

$x \quad$-EQUILIBRIO ENTRE AMBOS

Comentarios: Ambos elementos hace referencia a la realidad y nos cuentan una historia real.

Sin embargo las imágenes nos dan una visión diferente de lo que el texto nos dice, la visión del gato.

\section{TIPO DE HISTORIA}

\section{$\square$-NO CONTRADICTORIA (aunque alternativa)} $x$-CONTRADICTORIA (Ironía, humor...)

Comentarios: Aunque casi toda la historia es de contrapunto donde las imágenes nos muestran una historia contraria a lo que dice el texto, es cierto que ese contrapunto se acaba al final donde el texto se complementa con las imágenes y palabras e ilustraciones dicen lo mismo. Las imágenes en casi toda su totalidad contradicen al texto, añaden información visual con un toque irónico.

Mientras que el texto nos habla sobre lo que Matilda cree que le gusta a su gato, los dibujos nos hablan de que realmente eso no le gusta al gato, él se siente asustado e incluso aburrido. 


\section{FINAL}

$x$-CERRADO (única posibilidad)

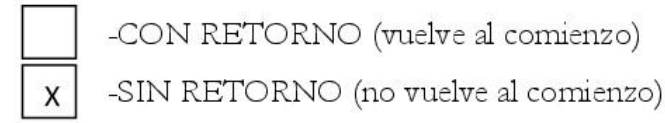

Comentarios: El final es sin retorno, puesto que no hace referencia al inicio de la historia, simplemente nos la aclara.

No obstante, es un final cerrado, ya que nos da na única posibilidad que da sentido a la historia en sí y a esa contradicción entre texto e imagen.

COMENTARIOS Y OBSERVACIONES: En este álbum, existe un equilibrio en cuanto a realismo entre imágenes y texto. Ambos nos cuentan una historia que podría suceder, aunque las ilustraciones nos dan el punto de vista del gato, mientras que las palabras, el punto de vista de la niña.

Las ilustraciones juegan un papel importante, que nos ayudan a aclarar y entender la historia y como lo que Matilda cree con total inocencia, no es lo que realmente su mascota piensa por ello la historia en cuanto a texto e imagen es contradictoria (salvo en el final).

El final cerrado da una sola interpretación tanto en imagen como en texto, donde podemos ver lo que realmente le gusta al gato, y es pasar tiempo con Matilda.

El libro nos habla sobre el cariño de una niña por su gato y viceversa, y de cómo Matilda disfruta jugando a lo que ella cree que le gusta a su mascota, pero al gato no le gustan todos esos juegos, el simplemente quiere estar con ella. 


\section{La princesa Listilla}

De Babette Cole (1998). Ed. Destino, S.A, Barcelona. (Internet archive:

https://archive.org/details/miscellaneouschioobabe)

-1º PUBLICACIÓN: Princess Smartypants (1986). Ed. Penguin group.

-RESUMEN: Una princesa vive muy bien soltera aunque sus padres se empeñan en casarla. Sin embargo los aspirantes han de pasar unas pruebas pero ninguno logra superarlas salvo el príncipe Fanfarroni. Cuando la princesa le da un beso, sucede algo.

\section{RELACIÓN TEXTO/ IMAGEN}

LO QUE CUENTA EL $\quad$ La princesa listilla no se quería casar porque vivía muy bien soltera, viviendo en el castillo con TEXTO $\quad$ sus mascotas y haciendo lo que le diera la gana. Sin embargo todos los príncipes querían casarse con ella y a su vez, los padres de ella estaban empeñados en que lo hiciera.

Asi que decidió casarse con aquel que cumpliera sus deseos como detener las babosas del jardín; dar de comer a sus animales; bailar sobre patines; atravesar el país en moto; rescatarla de la Torre; cortar leña en el bosque; amaestrar a su poni; acompañar a su madre la Reina de compras; o recuperar un anillo del estanque. Pero ninguno fue capaz de conseguirlo hasta que apareció el Príncipe Fanfarroni que logró pasar todas las pruebas y cuando la princesa le dio un beso mágico, lo convirtió en sapo gigante por lo que se marchó rápidamente.

Cuando todos los príncipes supieron que había sucedido, ninguno quiso casarse con la princesa, asi que vivió feliz para siempre.

El texto es bastante original, pero sencillo, diferente al que estamos acostumbrados a leer o escuchar en las historias típicas de princesas.

LO QUE CUENTA LA $\quad$ Una chica, vestida normal y corriente, realizando acciones normales y corrientes está rodeada IMAGEN de diferentes animales.

Ella sentada en un trono majestuoso y con cara de "pasotismo" se pinta las uñas mientras tres hombres elegantes se acercan a ella en un modo de intentar conquistarla. Pero ella sigue haciendo sus actividades en el jardín de un palacio, con sus animales fantásticos hasta que de repente, sucia y enfadada se dirige a sus padres, Rey y reina, algo le están diciendo que a ella no le convence.

Hombre tras hombre realizan una serie de acciones y se mezclan con sus seres extraordinarios pero acaban saliendo despavoridos, salvo uno, el cual realiza las mismas acciones sin problema.

La chica, la cual es princesa, le da un beso y lo convierte en un sapo desagradable, que de nuevo sale también despavorido en su coche, por lo que de nuevo la princesa, acaba realizando acciones normales y corrientes (como estar tumbada tomando el sol), rodeada de sus animales y seres extraordinarios.

Las ilustraciones son divertidas y originales, algo surrealistas.

\section{LO QUE NOS DICE LA HISTORIA EN CUANTO A TEXTO E IMAGEN EN SU CONJUNTO:}

La historia con toques de humor nos da una visión diferente de los cuentos de princesas, mezclando imágenes y palabras irónicas.

En este caso la princesa "Listilla", como su nombre indica, hace lo posible para ser independiente y vivir su vida como ella quiere. Por ello crea una serie de pruebas difíciles que sirven como excusa para que sus pretendientes nunca lleguen a ser su marido, por lo que todos los desafios dan con los puntos débiles de ellos. Asi pues, ella quedara soltera, hasta que un día un príncipe logra pasar cada obstáculo por lo que se convertida en su esposo, pero al darle un beso mágico, éste se convierte en un sapo gigante y sale corriendo del castillo.

Después de esto, la princesa puede de nuevo hacer lo que más le gustaba vivir en el castillo con sus mascotas y hacer todo lo que le viniera en gana. 


\section{RECURSOS UTILIZADOS:}

\begin{tabular}{|c|c|}
\hline \multicolumn{2}{|c|}{ NIVEL DE REALISMO (texto e imagen) } \\
\hline $\mathrm{X}$ & -TEXTO MÁS QUE IMAGEN \\
\hline & -IMAGEN MÁS QUE TEXTO \\
\hline & -EQUILIBRIO ENTRE AMBOS \\
\hline
\end{tabular}

Comentarios: El texto es el realista, ya que las ilustraciones nos cuentan algo más allá del texto, usando seres mágicos, monstruos y acciones atípicas a veces. El texto nos muestra la realidad de la historia y las imágenes nos ayudan a aclarar el texto, no todo lo que leemos es lo que parece, dándonos una visión más amplia de lo que realmente sucede. Por ejemplo, al hablar de alimentar a sus animalitos, podemos imaginar mascotas pequeñas, sin embargo son monstruos grandes y furiosos.
TIPO DE HISTORIA

$x$-NO CONTRADICTORIA (aunque alternativa) -CONTRADICTORIA (Ironía, humor...)

Comentarios: Las imágenes nos cuentan una historia alternativa a la del texto, en forma irónica. Mientras que el texto nos muestra una historia que podría ser real, las imágenes nos muestran las cosas más surrealistas, con animales que no existen, todo mucho más exagerado de lo que dicen las palabras. Por ejemplo cuando habla de detener a las babosas que se comen el jardín, en la realidad las babosas son insectos pequeños, pero aquí aparecen representados como seres gigantes, monstruos con colmillos que persiguen a los pretendientes.

\section{FINAL}

$x$-CERRADO (única posibilidad) -ABIERTO (diferentes posibilidades)

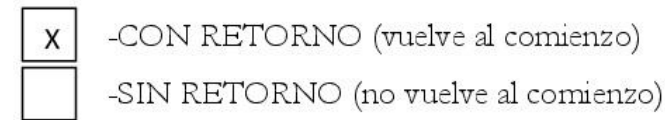

Comentarios: El final nos da una única posibilidad, a lo largo de la historia vemos que diferentes pretendientes intentan superar pruebas para poder casarse con la princesa, pero ninguno lo consigue. Sin embargo cuando llega el Príncipe Fanfarroni y consigue superarlas (por lo tanto debería ser el prometido de la princesa), esta lo convierte en sapo, se corre la voz y ninguno más intenta acercarse a la princesa, por lo que acaba con un final cerrado y de nuevo aparece disfrutando con sus animales, como al principio, es decir, vuelve al principio de la historia, es un final con retorno.

COMENTARIOS Y OBSERVACIONES: El álbum trata unos temas muy interesantes con una gran naturalidad, ya que vivimos en una sociedad llena de estereotipos, por lo que con toques de humor a la vez que ironía y doble sentido trata una historia a la que estamos acostumbrados (princesa bonita y rica que tiene que casarse con un príncipe), pero desde otro punto de vista. Aquí la princesa no quiere un príncipe, solo quiere vivir a su manera, sin tener que casarse, hacer lo que le apetece y convivir con sus mascotas, a pesar de la insistencia de los padres y pretendientes.

Es una gran historia que puede hacer comprender a los más pequeños que no siempre los cuentos de príncipes y princesas son con finales felices, o que todo los cuentos no se parecen a la vida real, donde se le da un gran valor a la mujer como persona independiente del hombre que puede buscarse la vida y disfrutarla sin ningún problema, a su manera.

En este libro existe la realidad de las palabras quedan por encima de lo que nos muestran las imágenes, ya que estas están llenas de elementos y personajes surrealistas que le dan más énfasis a lo que el texto dice, exagerando más aun la historia.

Las imágenes son increíbles, divertidas, cargadas de elementos y acciones que le dan poder a lo que se cuenta, donde sin contradecir a lo que el texto dice, nos aportan información extra.

La historia tiene final cerrado y con retorno, por lo que nos da una única posibilidad (la princesa se queda "soltera", haciendo lo que quiere y rodeada de sus animales, como al principio). 


\section{The trouble with mum}

\section{DATOS TEÓRICOS}

De Babette Cole (1984). Ed. Coward-McCann, New York. (Internet archive:

https://archive.org/details/troublewithmom00cole)

-1ºubICACIÓN: The trouble with mum (1983). Ed. Kaye \& Ward, Ltd, England.

-RESUMEN: La madre de un chico, en un principio no es aceptada por los demás padres de los niños de la

nueva escuela.

\section{RELACIÓN TEXTO/ IMAGEN}

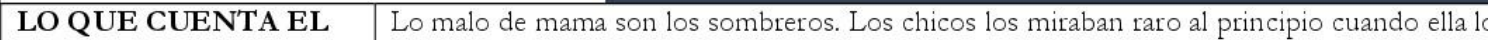
TEXTO

llevaba a la nueva escuela, además no se llevaba muy bien con los otros padres.

Cuando la maestra les pidió a las madres que hicieran dulces, su madre hizo algunos que fueron un desastre aunque a sus compañeros les encantaron, por lo que le preguntaron si podrían ir a su casa a jugar.

A pesar de pensar que no les gustaría su casa y de que los padres no los dejaban ir, los niños fueron de todos modos y se divirtieron muchísimo jugando con sus animales, conociendo a la abuela... hasta que aparecieron los padres de los niños estropeando todo y regañando a su madre. Tanto la madre como los niños estaban tristes porque no los dejarían jugar más en su casa, hasta que un día, la escuela se incendió y la madre corrió muchísimo para apagar el fuego antes de que llegara algún padre, por lo que se lo agradecieron muchísimo. Ahora juegan de nuevo en la casa todo lo que quieren.

El texto es sencillo, fácil de entender.

LO QUE CUENTA LA Una mujer (la madre) con sombrero extravagante y un niño normal y corriente van por el IMAGEN cielo volando con una escoba, mientras los niños acompañados de sus padres miran con cierta sorpresa.

En el pasillo de la escuela los padres la miran mal, por lo que los convierte en sapos.

La madre, que realmente es una bruja, prepara algo en un caldero, parecen ser dulces. Dulces llenos de insectos que no les gustan nada a los adultos que los prueban.

Todos los niños, compañeros de la escuela, van a un castillo con el niño protagonista y su madre (la bruja) y a pesar de parecer un castillo encantado con monstruos y más brujas, parece que se lo pasan genial.

Sin embargo los padres de los niños se los llevan aunque estos no quieren irse por lo que tanto ellos como la madre y el niño están tristes.

La escuela se incendia y la bruja arrastra unas nubes que con lluvia apagan el fuego, asi los padres de los niños se lo agradecen y acaban de nuevo jugando en la casa.

Las ilustraciones tienen muchísimos detalles y nos cuentan una historia diferente a lo que el texto dice.

\section{LO QUE NOS DICE LA HISTORIA EN CUANTO A TEXTO E IMAGEN EN SU CONJUNTO:}

La historia nos habla sobre un niño cuya madre es bruja. A los padres de sus nuevos compañeros no les gusta puesto que se comporta como tal (va volando a la escuela en su escoba, los convierte en sapo o hace dulces con insectos.

Sin embargo a los niños les encanta quieren ir a su casa, por lo que a pesar de que los padres se lo negaran, los compañeros acaban yendo a su casa que en realidad es un castillo encantado lleno de monstruos (que son las mascotas) y se lo pasan muy bien.

Cuando los padres se enteran de ello, van a por los niños y les prohíben ir más. Pero un día hay un incendio en la escuela y la bruja es capaz de mover las nubes a gran velocidad, para que apague el fuego, por lo que los padres finalmente acaban agradeciéndoselo y yendo a su casa de nuevo. 


\section{RECURSOS UTILIZADOS:}

\begin{tabular}{|c|c|}
\hline \multicolumn{2}{|r|}{ NIVEL DE REALISMO (texto e imagen) } \\
\hline$X$ & -TEX'TO MÁS QUE IMAGEN \\
\hline & -IMAGEN MÁS QUE TEXTO \\
\hline & -EQUILIBRIO ENTRE AMBOS \\
\hline $\begin{array}{l}\text { Co: } \\
\text { enc } \\
\text { surt } \\
\text { case } \\
\text { Por } \\
\text { mac } \\
\text { imá }\end{array}$ & $\begin{array}{l}\text { ntarios: El texto a nivel de realismo, queda por } \\
\text { de las imágenes, ya que estas usan elementos } \\
\text { istas y crean una historia de ficción llenas de brujas, } \\
\text { ncantadas, hechizos y monstruos (buenos). } \\
\text { mplo, al decir que todos les miraban raros cuando su } \\
\text { lo llevaba a la escuela nueva (un texto sencillo), las } \\
\text { es nos muestran a la madre bruja y su hijo yendo a la } \\
\text { en una escoba volando. }\end{array}$ \\
\hline
\end{tabular}

TIPO DE HISTORIA

$\square$-NO CONTRADICTORIA (aunque alternativa)

$x$-CONTRADICTORIA (Ironía, humor...)

Comentarios: Las imágenes nos cuentan una historia alternativa a la del texto, en toque de humor. Mientras que el texto nos muestra una historia que podría ser real, las imágenes nos muestran las cosas más surrealistas, castillos, monstruos como mascotas, sombreros con serpientes, pócimas, etc., aunque hace referencia al texto, nos cuenta una historia diferente, una historia fantástica y de ficción.

\section{FINAL}

$\mathrm{X}$

-CERRADO (única posibilidad)

$X$-CON RE'TORNO (vuelve al comienzo)

-ABIERTO (diferentes posibilidades)

-SIN RETORNO (no vuelve al comienzo)

Comentarios: El final nos da la única posibilidad de que finalmente madre e hijo se integran entre los compañeros y padres de estos, por lo que son aceptados al final.

A su vez, el final tiene parte de retorno aunque no concretamente con el principio, pero si con otra parte de la historia. De nuevo se ve a los niños en la casa jugando y divirtiéndose, como se ve en ilustraciones anteriores, por lo que hace de nuevo referencia a ellas.

COMENTARIOS Y OBSERVACIONES: A nivel de realismo, las palabras están por encima de las imágenes surrealistas.

Las imágenes, llenas de detalles y elementos ficticios, nos dan una historia diferente a la que en un principio podemos creer al leer el texto, por lo que con toque s de humor, contradicen a lo que el texto dice. Por ejemplo, el texto dice que los padres no se llevan demasiado bien, lo que no nos dice es que la bruja los ha convertido en sapos.

La historia tiene final cerrado y con retorno, por lo que nos da una única posibilidad (los padres de los niños acaban aceptándolos y dejan que sus hijos jueguen en la casa de los protagonistas (o según las ilustraciones, en el castillo encantado de la bruja).

El libro está lleno de sentido del humor y a partir de ello crea una historia que nos sirve para hablar sobre el rechazo social, aunque no literalmente, si no que juega con personajes y escenario ficticios (brujas, monstruos, castillos...). A los protagonistas al principio les cuesta integrarse, la gente ve mal sus acciones, hasta que un día, la madre "los salva" por lo que ahora si cambian sus puntos de vista y los ven con buenos ojos. En este caso, la bruja, al contrario de lo que estamos acostumbrados a ver, no es mala, solo actúa mal con quien no la acepta, sin embargo con los compañeros de su hijo, es muy buena. 


\section{Hushabye}

\section{DATOS TEÓRICOS}

De John Burningham (2001). Ed. Alfred A. Knopf, United States. (Internet archive: https://archive.org/details/hushabye00john)

-1 PUBLICACIÓN: Husherbye (2000). Ed. Jonathan Cape, Random House UK Limited, Britain.

-RESUMEN: Un gato, tres osos, un pez, un hombre, un ganso, una rana y un bebé buscan un lugar para irse a dormir al final del día.

\section{RELACIÓN TEXTO/ IMAGEN}

LO QUE CUENTA EL $\quad$ Una gata con un carrito de bebe ha tenido un día duro y necesita un lugar para que TEXTO sus gatitos se queden. Un bebe ha estado navegando en un barco y ahora necesita dormir. Hay tres osos cansados que están subiendo las escaleras, un pez en el mar cansado y un hombre en la luna que se dormirá pronto. Un ganso volando por el cielo y hay una rana que ha estado saltando todo el día con el calor, por lo que está cansada. Repentinamente se refiere a los lectores como si "ahora nosotros estamos cansados y necesitamos acostarnos, es la hora de dormir. Cuando sea por la mañana, nos levantaremos de nuevo", para acabar diciendo que el bebé se ha dormido en el barco y se balancea sobre las olas; los tres osos cansados están arropados en sus camas; el pez se ha quedado dormido en lo más profundo; el hombre de la luna no se despertara hasta mañana; el ganso y la rana también se han dormido.

Ahora tu estas arropado en la cama, con los pies calientes, lejos del viento y de la lluvia. Concluye con frases tranquilizadoras como "Tu cabeza está sobre la almohada". "Pronto estarás dormida". "Hushabye / hushabye/hush".

El texto es a veces irreal ya que habla de acciones poco o nada probables y puede con fundir. Si lo leemos en ingles vemos que está formado por rimas que cuentan la historia.

LO QUE CUENTA LA

IMAGEN pequeño que está a punto de dormirse, por lo que nos puede sugerir que la historia sirve para eso.

Ilustraciones dobles similares al libro de GRANPA, también de Burningham donde se suelen dividir en dos partes, la primera con imágenes monocromáticas y la segunda con imágenes a color llenas de color.

En las ilustraciones a color vemos un niño cansado sobre un barco; tres osos cansados subiendo unas escaleras; un pez en el mar, también cansado; un hombre encima de la luna a punto de quedarse dormido; un ganso volando; y una rana intentando cazar, también cansada. (Todos los animales aparecen personificados, vestidos como personas y realizando acciones humanas).

De repente aparece un campo con vacas durmiendo y un fondo rojo que podría simbolizar el anochecer, por lo que la mama gato y sus gatillos aparecen dormidos en un pajar; el niño dormido en su barco; los tres osos acostados en sus camas; el pez, en el fondo del mar dormido sobre el coral junto a un despertador; el hombre dormido encima de la luna; el ganso descansando en una silla que hay en un porche; la rana dormida en una hamaca colgante; y el campo de nuevo, pero con un fondo negro, que nos indica que ya ha anochecido.

Por otra parte las imágenes de un solo color nos explican hasta la mitad del libro (cuando aparece el campo de vacas) porque cada animal o persona está tan cansado, por ejemplo los osos que aparecen arrastrando un coche que se ha averiado, o un paisaje donde aparece un campo inmenso lo cual indica que la rana estuvo intentando cazar por allí. Y desde la mitad hasta el final, este tipo de ilustraciones son recuerdos o sueños que tienen mientras están durmiendo. 


\section{LO QUE NOS DICE LA HISTORIA EN CUANTO A TEXTO E IMAGEN EN SU CONJUNTO:}

Si empezamos por el título HUSHABYE, se observa que es una palabra compuesta por HUSH A BYE, que quiere decir algo como "silenciar un adiós", lo cual dará sentido al resto de historia. A su vez HUSHABY (sin "e") sirve para calmar a los niños pequeños, como una canción de cuna, asi que en este cuento Burningham ha jugado con ello, para hacer una canción de cuna ilustrada.

Nos presenta a una serie de personajes los cuales están cansados (en las imágenes monocromáticas explican el porqué del cansancio), para luego decir que se han quedado dormidos y pasar al lector (u oyente) con el fin de inducir al sueño.

Los dos tipos de imágenes sirven para diferenciar entre lo que dice el texto (imágenes a color) y los recuerdos o sueños.

\section{RECURSOS UTILIZADOS:}

\section{NIVEL DE REALISMO (texto e imagen) \\ -TEXTO MÁS QUE IMAGEN \\ -IMAGEN MÁS QUE TEXTO \\ $x \quad$-EQUILIBRIO ENTRE AMBOS}

Comentarios: Ambos son igualmente surrealistas. Aunque muestran personajes y escenarios reales, la personificación de los animales junto con la combinación de personajes con acciones y escenarios concretos, hace que la historia no tenga mucho sentido en cuanto a realidad. Que sea una historia de ficción.

\section{TIPO DE HISTORIA}

$x$-NO CONTRADICTORIA (aunque alternativa)

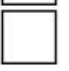
-CONTRADICTORIA (Ironía, humor...)

Comentarios: Las imágenes no contradicen al texto, sino que añaden información visual por encima de lo que las palabras dicen. Por un lado el texto, apoyado de imágenes a color, cuentan una historia, mientras que por otro, las imágenes a un solo color, nos dan información extra, contándonos otra historia que no aparece en el texto y sirve para explicar la historia.

\section{FINAL}

$\mathrm{X}$

-CERRADO (única posibilidad) -ABIERTO (diferentes posibilidades)

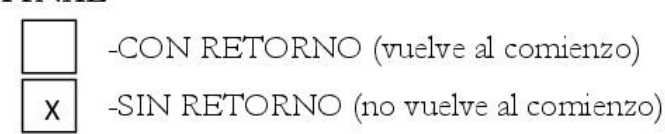

Comentarios: La historia en sí va un poco en bucle, hablando desde el cansancio de los personajes (porque han estado todo el día haciendo algo), hasta que se quedan dormidos. Sin embargo el final se sale de la historia para dirigirse al espectador. La historia empieza por la mañana, sigue con el atardecer y acaba con la noche, por lo que no tiene retorno.

Además el final es cerrado puesto que nos da la única posibilidad de que ha caído la noche y todos están durmiendo.

COMENTARIOS Y OBSERVACIONES: El libro es un cuento hecho exclusivo para que los niños duerman. A lo largo de la historia habla de cada personaje los cuales están cansados y quieren ir a dormir hasta que al final lo consiguen (cada uno en el lugar que elige lo cual va desde sitios más convencionales a sitios surrealistas (como la luna, o él bebe en un barco), para proseguir luego con palabras que cada vez se hacen más pequeñas, lo cual es como si la voz al leerlo fuera cada vez más baja mientras da pautas para relajar al niño como: "Tu cabeza está sobre la almohada", "Pronto caerás dormido", "Hushabye" (silenciar un adiós), "Hush" (silencio).

Por ello es un libro surrealista tanto en imágenes como en texto, aunque el empleo de las imágenes (en este caso a color y a un solo color para diferenciar que es lo que aparece en el texto y que queda fuera, pero nos aclara lo que dice la historia con una historia alternativa) es muy importante. 


\section{4. ¿Todavía nada?}

\section{DATOS TEÓRICOS}

De Christian Voltz (2003). Ed. Kalandraka, Pontevedra. (Biblioteca Ugr de Educación)

-1ºuBLICACIÓN: Toujours rien .(1997). Ed. Rouergue, France.

087.5

VOL

tod

-RESUMEN: Una mañana, el señor Luis planta una semilla y la riega con el fin de que brote algo, sin embargo día tras día va a ver, pero nada crece hasta que al final sucede algo.

\section{RELACIÓN TEXTO/ IMAGEN}

\begin{tabular}{|c|c|}
\hline $\begin{array}{l}\text { LO QUE CUENTA EL } \\
\text { TEXTO }\end{array}$ & $\begin{array}{l}\text { Una mañana, el señor Luis cavó un hoyo enorme y dejo caer una semilla. Luego lo rellenó, } \\
\text { regó y dijo "te estaré esperando". Al día siguiente el señor fue a ver si había brotado algo, } \\
\text { pero aún no había nada puesto que era demasiado pronto por lo que le dijo a un pájaro que } \\
\text { había por allí "hay que tener paciencia". Al día siguiente sucedió lo mismo, y asi sucesivamente } \\
\text { hasta que se cansó y pensó que no merecía la pena volver. } \\
\text { Pero un día el pájaro decide regalarle la flor a su novia, por lo que el señor Luis que volvió al } \\
\text { día siguiente dijo " ¿todavía nada?". }\end{array}$ \\
\hline $\begin{array}{l}\text { LO QUE CUENTA LA } \\
\text { IMAGEN }\end{array}$ & $\begin{array}{l}\text { Un señor cava un hoyo y arroja una semilla, la riega y esta empieza a crecer, y crecer, pero } \\
\text { cuando atraviesa la tierra se convierte en flor. Esta flor es arrancada por un pájaro que se la } \\
\text { lleva. De nuevo aparece el señor que mira a la tierra sin ver fruto alguno. }\end{array}$ \\
\hline
\end{tabular}

\section{LO QUE NOS DICE LA HISTORIA EN CUANTO A TEXTO E IMAGEN EN SU CONJUNTO:}

El señor Luis que una mañana planta una semilla y la riega a la espera de que crezca, la observa diariamente pero no ve cambio alguno. Mientras le dice a un pájaro que ronda por allí que hay que tener paciencia, sin embargo, harto de estar esperando decide no volver al día siguiente. Lo que no se dice pero se ve, es que bajo tierra la semilla sí que está germinando, por lo que cuando crece y se convierte en flor el pájaro de antes se la lleva, dejándola de nuevo sin flor. Al día siguiente cuando el señor Luis va de nuevo, sigue sin ver algún avance.

Luis no ha tenido la paciencia suficiente, cosa que el pájaro que no se queja, sí. Asi el pájaro es el beneficiario final.

\section{RECURSOS UTILIZADOS:}

\section{NIVEL DE REALISMO (texto e imagen) \\ -TEXTO MÁS QUE IMAGEN

$$
\text { -IMAGEN MÁS QUE TEXTO }
$$ \\ $x$-EQUILIBRIO ENTRE AMBOS}

Comentarios: Aunque las imágenes estén hechas con recortes y piezas, tienen el mismo nivel de realismo que el texto. Ambos cuentan una historia que podría ser real, hasta que el pájaro humanizado habla.

\section{TIPO DE HISTORIA}

$x$-NO CONTRADICTORIA (aunque alternativa) -CONTRADICTORIA (Ironía, humor...)

Comentarios: Las imágenes crean una historia alternativa donde las ilustraciones muestran la semilla creciendo bajo tierra, y el texto nos habla tan solo de lo que el señor ve (por lo tanto lo que hay debajo de la tierra no puede verlo).

\section{FINAL}

$x$-CERRADO (única posibilidad) -ABIERTO (diferentes posibilidades)

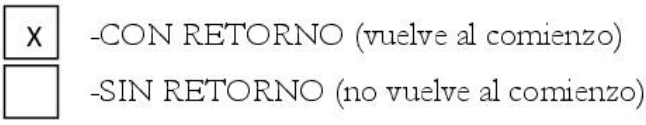

-SIN RETORNO (no vuelve al comienzo)

Comentarios: El final nos da la única posibilidad de que la semilla no brota, puesto que ya ha brotado y el pájaro se ha llevado la flor. Asi pues hace referencia al principio ya que nos muestra el ciclo de una planta. 
COMENTARIOS Y OBSERVACIONES: Este álbum original emplea papeles, alambres, tuercas, cuerdas, etc, para crear unos personajes y fondos diferentes. La historia nos habla sobre que hay que ser paciente, puesto que a veces nuestra impaciencia hace que nos perdamos grandes cosas, asi mismo nos habla también sobre el ciclo de la planta desde que se planta la semilla, hasta que se forma una flor. Estos temas son muy interesantes para tratar con los niños.

Mediante las imágenes, se cuenta una historia alternativa, una historia que va más allá de lo que el protagonista ve.

El final cerrado nos habla de la "perdida" de la flor que ha germinado y ha sido arrancada por el personaje que más paciencia tuvo y que no se quejó. 


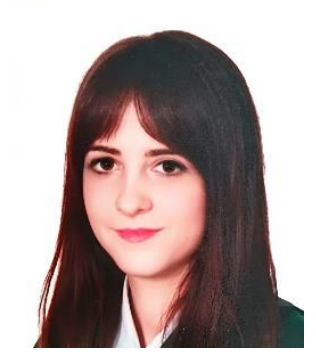

Nombre y Apellidos: Marta Vélez Borja.

Título académico: Grado en educación primaria 2010-2015. Universidad de Granada.

Dirección Postal: C/ Rodriguez de la fuente, 10. CP: 18110, Las Gabias (Granada).

Dirección electrónica: martavb89@ hotmail.com 